UNIVERSIDADE DE BRASÍLIA

INSTITUTO DE CIÊNCIAS HUMANAS

DEPARTAMENTO DE HISTÓRIA

PROGRAMA DE PÓS-GRADUAÇÃO EM HISTÓRIA

DIOGO D’ANGELO DE ARAUJO RORIZ

Os radicais no poder: $\mathrm{O}$ jornal La Nación e o segundo governo de Hipólito Yrigoyen (1928-1930) 
DIOGO D’ANGELO DE ARAUJO RORIZ

Os radicais no poder: $\mathrm{O}$ jornal La Nación e o segundo governo de Hipólito Yrigoyen (1928-1930)

Dissertação apresentada ao Programa de Pós-Graduação em História da Universidade de Brasília (UnB), como requisito para a obtenção do título de mestre em História. Linha de Pesquisa: Política, Instituições e Relações de Poder.

Orientador: Prof. Dr. Francisco Fernando Monteoliva Doratioto.

Brasília, 2017 


\section{Os radicais no poder: $\mathrm{O}$ jornal La Nación e o segundo governo de Hipólito Yrigoyen (1928-1930)}

Dissertação de mestrado submetida ao Programa de Pós-Graduação em História da Universidade de Brasília (UnB), como parte dos requisitos necessários à obtenção do título de mestre em História.

BANCA EXAMINADORA

Prof. Dr. Francisco Fernando Monteoliva Doratioto (Presidente) - UnB

Prof. Dr. Antonio José Barbosa - (Avaliador) - UnB

Prof. Dr. Carlos Eduardo Vidigal (Avaliador) - UnB

Profa. Dra. Neuma Brilhante Rodrigues (Suplente) - UnB 
À Santíssima Trindade.

À Maria Santíssima, Mater nostri Redemptoris.

A São Judas Tadeu e a todos os Santos.

À minha amada família.

À Natália.

À minha avó Laudicena, eterna intercessora pessoal, in memoriam. 


\section{Agradecimentos}

Esta dissertação de mestrado não pode ser entendida como um esforço unicamente pessoal, uma vez que a sua conclusão somente foi possível graças ao empreendimento colaborativo de muitas boas almas, as quais souberam ajudar-me nos mais difíceis momentos pelos quais passei nos últimos dois anos.

Primeiramente, e sempre acima de todas as coisas, devoto infinita adoração a Deus, promotor de todas as graças que de Sua liberalidade tenho recebido em minha vida. Agradeço, portanto, a Deus Pai, per quem ómnia facta sunt, Deus Filho, Dóminum Jesum Christum, Fílium Dei unigenitum, et ex Patre natum, ante ómnia sacula, e ao Espírito Santo Paráclito, Dóminum et vivificántem, qui ex Patre, Filióque procédit. Qui cum Patre, et Fílio simul adorátur, et conglorificátur, qui locutus est per Prophétas. Ainda, à Virgem Santíssima, que sempre me guardou e protegeu em seu sagrado coração. A ti, ó Mãe, toda a minha devoção, “Tuus totus ego sum, et omnia mea tua sunt”. Por fim, à Igreja, Una, Santa, Católica, Apostólica e Romana, Corpo Místico de Cristo, que pela administração dos sacramentos divinos levou-me a Verdade, e a todos os anjos e santos de Deus, especialmente aos meus intercessores, São Judas Tadeu, São Bento de Núrcia e Santa Teresa D'Avila.

Minha gratidão aos meus amados familiares, que em sua ternura, proteção e companheirismo serviram de suporte a mim nas muitas dificuldades e sofrimentos. Ao meu pai, herói, amigo e meu maior exemplo, e a minha mãe, por seu carinho inesgotável, amor insuperável e piedosas orações. Ao meu irmão Sidney e a sua família, pelo amor que sempre dispenderam gratuitamente a mim. Ao meu amor, Natália de La Cruz, fiel companheira e futura esposa, que sempre me apoiou e protegeu em nossa caminhada conjunta.

Agradeço também aos companheiros de guerra: Pedro Soares, Felipe, Gustavo, Adrian, Pe. Fernando, Jorge e Rodrigo Piubelli, bem como aos demais amigos e amigas de peito, rogo para que Deus os retribua imensamente. Rendo um especial agradecimento ao meu orientador, Francisco Doratioto, pela perseverança e inestimável apoio devotado a minha formação intelectual ao longo dos últimos 6 anos, e sobretudo nos últimos meses, onde demonstrou ser não só um grande intelectual, como também um grande amigo.

Não posso deixar de agradecer à divisão de microfilmes da Hemeroteca da Biblioteca do Congreso de la Nación, situada em Buenos Aires, Argentina. Meus agradecimentos aos funcionários, por seu apoio técnico e paciência. 
Por fim, agradeço à Universidade de Brasília, ao seu Programa de Pós-Graduação em História e à Coordenação de Aperfeiçoamento de Pessoal de Nível Superior (CAPES) pelo apoio institucional e pela bolsa de estudos. 


\title{
Os radicais no poder: O jornal La Nación e o segundo governo de Hipólito Yrigoyen (1928-1930)
}

\begin{abstract}
RESUMO
Este trabalho busca compreender os posicionamentos públicos adotados pelo jornal argentino La Nación em relação à segunda presidência de Hipólito Yrigoyen, entre os anos de 1928 e 1930. O período em tela, marcado por confrontos políticos e findado por uma traumática intervenção militar que depôs o governo vigente, evidencia-se como um divisor de águas na recente história política argentina, justificando-se, assim, a importância de se entender os rumos adotados pelo mais influente jornal argentino daquele momento. De modo a alcançar os objetivos desta dissertação, foram analisados os editoriais publicados pelo jornal ao longo do corte cronológico supracitado, visando a explicitar seus posicionamentos acerca de diversos temas de elevado interesse nacional neste período, bem como em relação à queda do governo. As conclusões deste estudo afirmam a ferrenha, crítica e, por vezes, beligerante oposição feita pelo jornal ao governo, sem, no entanto, encontrar evidências claras de apoio à intervenção militar de 1930.
\end{abstract}

Palavras-chave: La Nación; União Cívica Radical; Hipólito Yrigoyen; 1930. 


\title{
The radicals in power: The newspaper La Nación and the second government of Hipólito Yrigoyen (1928-1930)
}

\begin{abstract}
The present work seeks to understand the public instances adopted by the Argentinian newspaper La Nación regarding the second presidential term of Hipólito Yrigoyen, from 1928 to 1930 . The studied period, marked by political clashes and finished by a traumatic military coup, which overthrew the government, appears as a watershed on the recent political history of Argentina, thus justifying the importance to comprehend the directions adopted by the most influential Argentinian newspaper of that time. In order to achieve the objectives of this dissertation, the editorial articles published by the newspaper during said chronological time were analyzed to explain the instances of La Nación regarding several matters of high national concern, as well as regarding to the debacle of the government. The conclusions of this work assert the ferocious, critical and at times belligerent opposition made by the newspaper against the government without, however, finding clear evidence of support to the military coup of 1930.
\end{abstract}

Key words: La Nación; Radical Civic Union; Hipólito Yrigoyen; 1930 


\section{Sumário}

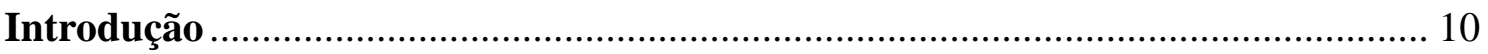

1. A Argentina contemporânea: o desenrolar da história política (1810-1910) ...... 17

1.1 Surgimento das Províncias Unidas do Rio da Prata (1810-1852) ........................ 17

1.2 A unificação argentina (1852-1880) .................................................................... 19

1.3 O Roquismo e a égide do Estado argentino moderno (1880-1890)..................... 24

1.4 Da Revolução do Parque à ascensão da União Cívica Radical (1890-1912) ....... 31

2. Imprensa argentina e período radical (1916-1928) …........................................ 44

2.1 Entre palácios e barricadas: uma breve história de Bartolomé Mitre e do jornal La

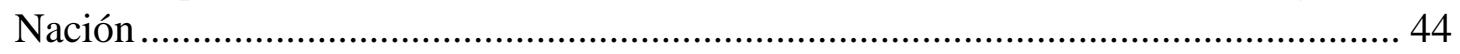

2.2 Os outros veículos de imprensa opositores: o movimento nacionalista ............... 48

2.3 Do primeiro governo de Hipólito Yrigoyen (1916-1922) ..................................... 54

2.4 Do governo do presidente Alvear (1922-1928) ................................................. 64

3. O Jornal La Nación e a Intervenção militar de 1930 ............................................ 70

3.1 As eleições de 1928 e o ressurgimento de Hipólito Yrigoyen.............................. 73

3.2 "Temas de la actualidad nacional": as grandes questões nacionais no despontar do

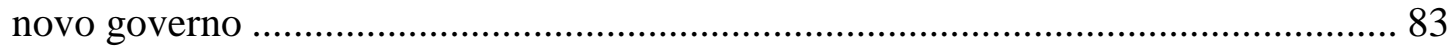

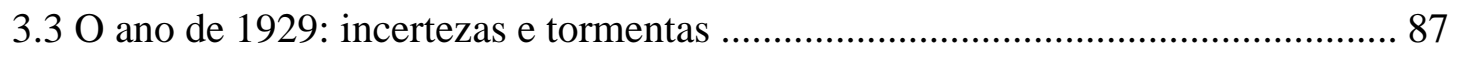

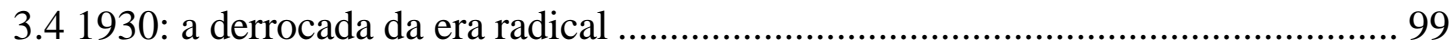

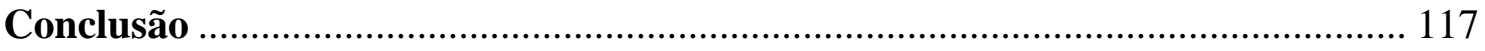

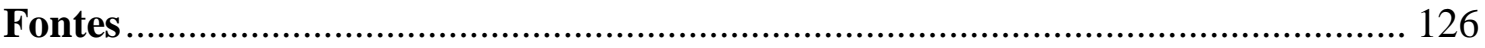

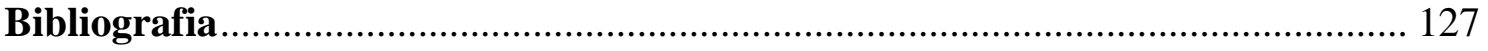


Introdução

O período histórico desenrolado entre 1916 e 1930 na Argentina, apesar de sua riqueza e significância para a história deste país, não se encontra no rol das principais preocupações da historiografia argentina. Todavia, vários historiadores argentinistas têm se dedicado ao seu estudo ao longo das últimas décadas, em especial a partir da redemocratização do país nos anos 1980.

Na mesma medida, os 14 anos de governos radicais existentes nesse período ainda não encontraram o mesmo eco de importância de outros contextos da história daquele país. Localizados entre dois gigantes da historiografia argentina, o período liberalconservador e as décadas de 1930 e 40 com a respectiva ascensão do peronismo, o período radical foi sujeitado, por parcela significativa da historiografia tradicional, ao posto de coadjuvante do processo histórico argentino. Este período é, costumeiramente rememorado à luz do fim da hegemonia liberal-conservadora e/ou da sua "restauração"1.

Deparei-me com essas questões ainda cedo durante o curso de graduação, quando realizei as minhas primeiras pesquisas em história da Argentina. O meu encontro com este país e, mais exatamente, com o período aqui em questão, deu-se em face do interesse primeiramente suscitado por meu orientador Francisco Doratioto, que me apontou a década de 1920 como um corte cronológico parcamente estudado a fundo, que poderia constituir um objeto estimulante de pesquisa.

Sob sua orientação, desenvolvi uma monografia de conclusão de curso sobre o despontar do movimento nacionalista argentino no pós-Primeira Guerra Mundial. Nela estudei o engajamento político dos principais expoentes do nacionalismo argentino e sua relação com o Poder. Durante a pesquisa, tive acesso aos escritos desses intelectuais, bem como aos seus discursos e práticas políticas, e por meio dessas fontes, em sua maioria publicadas em pequenos jornais e revistas, surgiu-me o objetivo de melhor compreender

\footnotetext{
${ }^{1}$ O termo "restauração conservadora", datada em 1930 com a queda de Yrigoyen, tornou-se uma comum em parte da historiografia clássica.
} 
a relação da imprensa argentina para com os governos ali vigentes, sobretudo em relação às suas posições políticas.

Após passar em revista a bibliografia concernente ao período e iniciar as pesquisas de fontes, confirmei que os grandes veículos de imprensa do país poderiam me servir de ancoragem para compreender o desenrolar deste riquíssimo período histórico. Decidi me voltar para o jornal La Nación, um dos mais antigos, e ainda hoje em circulação, constituindo-se no mais importante periódico do país. Sua escolha não foi despretensiosa, mas sim proposital, pois o seu alcance social, sobretudo entre as elites políticas e econômicas do país era marcante, o que podia ser verificado nas fontes abordadas desde as minhas primeiras pesquisas.

Outro fator que me ajudou a escolher o La Nación como fonte de pesquisa foi a sua intricada relação com a própria história argentina. Seu fundador foi Bartolomé Mitre, um importante político e intelectual do século XIX, cuja atuação e história pessoal se confundem com a história de seu país à época. Outrossim, desde a sua fundação, o jornal teve como premissa primordial ser um jornal de doutrinas, cujos posicionamentos políticos pudessem ser facilmente verificados pelo seu leitor.

O corte cronológico, por sua vez, foi escolhido com base na tipologia documental que serviu de base para este trabalho. Escolhi estudar, prioritariamente, os editoriais do jornal, local onde melhor se reconhece a propagação das opiniões privadas de um veículo de comunicação acerca de temas variados, desde política à cultura e atualidades. Previamente, já havia se verificado que os editoriais do La Nación eram uma rica fonte de estudo dos seus posicionamentos políticos, bem como de sua atuação frente aos governos vigentes. No entanto, por se tratar de um jornal com circulação diária, urgia escolher um período cronológico que permitisse alcançar o objetivo da dissertação, evitando que fosse desnecessariamente extenso ou excessivamente curto.

Optei, portanto, por defrontar o jornal La Nación e sua atuação política com o momento mais instigante do período radical, justamente os dois últimos anos, 1928 a 1930. Neles transparece o retorno de Hipólito Yrigoyen ao poder, a oposição a ele do liberalismo com o qual La Nación identificava-se, a crise e depois a derrubada pela intervenção militar em 6 de setembro de 1930.

Para compreender e analisar este período histórico, foi indispensável o estudo e apoio de uma vasta bibliografia, que se inseriu em dois campos historiográficos, a saber: a historiografia sobre a construção do Estado argentino e a sua consolidação ao longo do 
século XIX (1810-1912), e aquela sobre o período radical e de seus principais personagens e movimentos políticos (1912-1930).

Para a realização desta pesquisa, recorreu-se a dois grupos de fontes primárias: as edições microfilmadas do jornal La Nación correspondentes ao corte cronológico do trabalho, guardadas na Hemeroteca da Biblioteca do Congresso de La Nación, em Buenos Aires, e outros jornais e revistas contemporâneos ao corte cronológico.

No primeiro corpo de fontes, cuja pesquisa foi realizada pessoalmente em Buenos Aires, analisou-se as opiniões do jornal em relação à atuação de Hipólito Yrigoyen e de seu gabinete governamental durante seu segundo governo. Também procurou-se identificar como o La Nación via as principais questões políticas, econômicas e sociais do país durante o período pesquisado.

O segundo corpo de fontes teve duas funções distintas. A primeira foi expandir a oposição ao radicalismo para além do La Nación, a partir de discursos e pensamentos de intelectuais nacionalistas que atuaram firmemente contra a União Cívica Radical durante a década de 1920. Em segundo lugar, serviu como base de comparação e, em determinados momentos, como preenchimento de lacunas deixadas pelo jornal, tanto em face de posicionamentos mal elaborados pelo periódico quanto em face de inexistência de material deste acerca de certos acontecimentos do país.

Para melhor fundamentar as análises e interpretações propostas ao longo da pesquisa, bem como alcançar os objetivos propostos, foi necessário recorrer a alguns aportes teóricos, sobretudo quanto à utilização de determinados conceitos políticos e em relação à teoria da imprensa. Destaca-se que muitos dos conceitos costumeiramente utilizados pela historiografia como um todo carecem, geralmente, de contextualização e abordagens empíricas. Como aponta o teórico da história Reinhart Koselleck, conceitos políticos podem abarcar uma gama de possíveis interpretações, e seus significados variam conforme o local e tempo em que são utilizados. Assim, a utilização de um conceito político fora de seu tempo e espaço originários, sem a devida contextualização, pode incorrer em uma extrapolação semântica do mesmo, ou ainda à importação de ideias cristalizadas, sem relação alguma com o contexto analisado. ${ }^{2}$

Koselleck ainda aponta para o uso recorrente em pesquisas históricas de conceitos antitéticos assimétricos $^{3}$, que se refere aos pares opostos, como direita/esquerda e

\footnotetext{
${ }^{2}$ KOSELLECK, Reinhart. Futuro passado: contribuição à semântica dos tempos históricos. Rio de Janeiro: Contraponto, 2006, p. 191.

${ }^{3}$ Idem, pág. 193.
} 
liberalismo/conservadorismo. Eles surgem de uma construção taxativa e autoritária realizada pelo historiador ao tratar de forma despercebida e descuidada, do ponto de vista semântico e conceitual, o seu objeto de estudo, com vistas a legitimar um pressuposto teórico pessoal que extrapola os conceitos utilizados. A escrita historiográfica se conecta com a linguagem utilizada pelo pesquisador, é ela que dota o passado de realidade, tornando-se muito perigoso a livre utilização de conceitos complexos sem a mínima contextualização dos mesmos ${ }^{4}$.

Dentre os conceitos aqui analisados, encontram-se o de liberalismo, conservadorismo e elites. Ambos procedem do contexto sócio-político europeu do fim do século XVIII e início do século XIX, os quais tiveram forte influência sobre as revoluções de independência no continente americano. No contexto argentino, e para efeito de análise dessa pesquisa, concorda-se com Oscar Cornblit, o qual encara que ambos conceitos foram utilizados à época dentro de um bojo de ideias similares ${ }^{5}$, diferenciando-se claramente do contexto europeu, onde liberalismo e conservadorismo se diferenciavam em termos ideológicos.

No caso argentino, conforme aponta Cornbilt, tanto o conceito de liberalismo quanto o de conservadorismo denotavam a defesa das liberdades individuais, dos direitos conquistados ao longo do processo revolucionário de independência e da Constituição nacional vigente ${ }^{6}$. A única diferença se dava em relação a determinadas posições no campo social e cultural, sendo o liberalismo, conforme coloca Shumway, mais identificado com Buenos aires e as classes cultas, bem como com a cultura laica, e o conservadorismo mais relacionado com os interesses tradicionais das elites agrárias. ${ }^{7}$

Quanto ao conceito de elites, amplamente discutido pela teoria das elites ${ }^{8}$, concorda-se nesta pesquisa com a conceituação clássica de Vilfredo Pareto, conforme

\footnotetext{
${ }^{4}$ KIRSCHNER, Tereza. A reflexão conceitual na prática historiográfica. Textos de História, vol. 15, nº 1/2, 2007. Disponível em: http://seer.bce.unb.br/index.php/textos/article/view/959. Acesso em: 20 novembro 2015, p. 2.

${ }^{5}$ CORNBILT, Oscar. La opción conservadora en la política argentina. Desarrollo Económico, vol. 14, $\mathrm{n}^{\circ}$ 56, 1975. Disponível em: http://www.educ.ar. Acesso em: 14 setembro 2014, pág. 6.

${ }^{6}$ Idem, pág. 7.

${ }^{7}$ SHUMWAY, Nicolás. La Invención de la Argentina: Historia de una Idea. 2 ed. Buenos Aires: Emecé, 2002, p. 233.

${ }^{8}$ Teoria segundo a qual, em todas as sociedades, existem minorias que são detentoras do poder local, em oposição à maioria da população, dele alejada. A teoria das elites começou a ser debatida no fim do século XIX pelos italianos Gaetano Mosca e Vilfredo Pareto, e desde então já foi alvo de heterogêneas análises mundo a fora, especialmente em meio à escola norte-americana. Para melhor se compreender o tema, destaca-se:

Teoria das Elites In BOBBIO, Norberto; PASQUINO Gianfranco. Dicionário de Política. Brasília, Ed. UnB, $13^{\text {a }}$ ed. 2007, pág. 385.
} 
apresentado por Raymond Aron, segundo a qual a elite representa um pequeno número de indivíduos não homogêneos ideologicamente, e com origens sociais diversas, que, aquém de suas linhas de ação, conseguiram ocupar os altos escalões da hierarquia profissional, política e social. Assim, conforme Aron, "não precisamos indagar se a elite é verdadeira ou falsa, e quem tem o direito de figurar nela. Todas essas questões são vãs. A elite está composta dos que mereceram boas notas no concurso da vida, ou tiveram sorte na loteria da existência social"9.

A história da imprensa argentina, por sua vez, está entrelaçada com o desenrolar da história política daquela nação desde os seus primórdios, e, sobretudo, ao longo dos principais acontecimentos políticos que incendiaram os editoriais dos grandes jornais, revistas e folhetins argentinos. O protagonismo da imprensa em meio ao desenrolar político se baseou muito mais em ativa participação política por fins ideológicopartidários do que por mera manipulação da opinião pública. Desde o princípio, quando o primeiro folhetim foi redigido sob a égide do novo Estado-nação em 1810, os meios midiáticos deram passos rumo aos gabinetes e palácios.

Um grande número de intelectuais se debruçou ao longo dos dois últimos séculos sobre o estudo da história da imprensa argentina. Alguns dos próprios personagens políticos centrais analisados nesta dissertação, figuras de grande calado político como Sarmiento, Alberdi, Bartolomé Mitre e Roca, os quais fizeram uso desses periódicos como forma de divulgação de seus ideais pessoais e de seus pares, também foram grandes expoentes no estudo do tema. Foi em torno do centenário Círculo de la Prensa que diversos pensadores e homens das letras se reuniram ao longo de décadas a fim de recontar a história dos principais meios de comunicação do país, o que levava, outrossim, ao estudo da própria política nacional e de seus mais influentes observadores.

Fundado em 1891 sob a alcunha Círculo de Cronistas, o Círculo de la Prensa ${ }^{10}$ somente veio a receber essa denominação no ano de 1896. Seu primeiro presidente foi Bartolomé Mitre, que estava então à frente do jornal La Nación. Tratava-se de uma

GRYNSZPAN, Mário. Ciência política e trajetórias sociais: uma sociologia histórica da teoria das elites. Rio de Janeiro: Ed. Fundação Getulio Vargas, 1999. 255p.

JUNIOR, Antonio Carlos Dias. Raymond Aron leitor de Vilfredo Pareto: classe sociais, circulação de elites e mudança social. GT 29 - Teoria Social Contemporânea. XXX Congresso da Associação Latinoamericana de Sociologia. 2015. Disponível em: http://ciem.ucr.ac.cr/alas/docs/GT29/Raymond\%20aron \%20leitor\%20de\%20vilfredo\%20pareto\%20classes $\% 20$ sociais $\% 20$ circula $\%$ C3\%A 7\%C3\%A3o\%20das\%20elites\%20e\%20mudan\%C3\%A7a\%20social.docx . Acesso em: 03 janeiro 2016.

${ }^{9}$ ARON, Raymond. Etapas do pensamento sociológico. Brasília: Editora da UnB, 1990, pág. 479.

${ }^{10}$ BELTRAN, Oscar R. Historia del Periodismo Argentino. Buenos Aires: Sopena Argentina, 1943, p. 272. 
espécie de "círculos dos ilustres", parte importante do ciclo social da alta elite política e intelectual portenha a partir do fim do século XIX. O objetivo geral do Círculo era servir de espaço de reunião dos homens ilustres de Buenos Aires visando-se o estudo e monitoramento da imprensa nacional, sobretudo no que tange à limitação da liberdade de expressão de cada um dos veículos de imprensa ali representados.

Ao longo dos anos, a administração do Círculo de la Prensa passou por diversas transformações, ora aproximando-se, ora afastando-se do centro de poder vigente. Três obras clássicas acerca da história da imprensa argentina foram publicadas, sejam financiadas, seja de algum modo entrelaçadas com os rumos tomados pelo Círculo, em um dos momentos de maior aproximação política do instituto para com o governo central: a década de 1940.

Em 1941, o Círculo de la Prensa realizava o seu $1^{\circ}$ Concurso literário, sobre obras que contassem a história dos periódicos e da imprensa argentina. Cerca de 9 obras foram apresentadas à Comissão Julgadora responsável pelo concurso, das quais a grande vencedora foi a Historia del Periodismo Argentino de Juan Romulo Fernandez ${ }^{11}$. Outras duas obras, que estiveram relacionadas com o mesmo concurso, foram publicadas posteriormente nos anos de 1943 e 1944, respectivamente. Trata-se da "Historia del Periodismo Argentino: pensamiento y obra de los forjadores de la pátria" ${ }^{12}$, de Oscar Beltran, e "El Periodismo Argentino: amplia y documentada historia desde sus origenes hasta el presente" ${ }^{\prime 13}$, de Carlos Galvan Moreno.

As três obras aqui mencionadas servirão de base para a breve análise da história da imprensa argentina aplicada ao período em corte, iniciando-se pelo próprio jornal La Nación. Acrescenta-se às obras mencionadas os dois livros mais recentes sobre o tema de Carlos Ulanovsky ${ }^{14}$.

A dissertação está dividida em três capítulos. O primeiro aborda os antecendentes históricos do contexto analisado, partindo-se das disputas e debates ideológicos que levaram à formação do Estado argentino em 1862, e passando pela consolidação do modelo liberal-conservador sob a tutela do Partido Autonomista Nacional entre 1880 e

\footnotetext{
${ }^{11}$ FERNANDEZ, Juan Rómulo. Historia del Periodismo Argentino. Buenos Aires: Libreria Perlado, 1943.

${ }^{12}$ BELTRAN, Idem.

${ }^{13}$ GALVAN MORENO, Carlos. El periodismo argentino: amplia y documentada historia desde sus origenes hasta el presente. Buenos Aires: Claridad, 1944.

${ }^{14}$ Ulanovsky, Carlos. Paren las rotativas: una historia de grandes diarios, revistas y periodistas argentinos. Buenos Aires: Espasa Calpe, 1997.
} Carlos. Paren las rotativas I: 1920 - 1969. Buenos Aires: Emecé, 2005. 
1912, pela reforma eleitoral do presidente Roque Sáenz Peña e culminando na chegada da União Cívica Radical ao poder em 1916. O segundo capítulo faz a contextualização histórica acerca do jornal La Nación, apresenta Bartolomé Mitre, seu fundador, bem como as principais questões políticas, econômicas e sociais em voga entre 1916 e 1930. Assentua-se ainda os diversos grupos opositores ao radicalismo, em especial a Yrigoyen, desde os liberais-conservadores até o nascente movimento nacionalista. Por último, no terceiro capítulo são analisados os editoriais do La Nación, identificando seus posicionamentos políticos e ideológicos em relação ao segundo mandato presidencial do radical Hipólito Yrigoyen. 


\section{A Argentina contemporânea: o desenrolar da história política (1810-1910)}

Ao longo do Século XIX o continente americano assistiu a uma profusão de ideias revolucionárias em seu seio. Foram as Treze Colônias britânicas, futuro Estados Unidos da América, que trouxeram para este continente o ideal de rompimento com a dependência colonial e a aspiração pela criação de novas e soberanas nações no Novo mundo. Tais ideais libertários foram transportados do Velho mundo por meio de navios, panfletos e armas. Não obstante, instiga-nos a memória o importante papel representado pela mídia impressa na divulgação de obras libertárias por toda a Europa e América. ${ }^{15}$

Por detrás deste insipiente cenário revolucionário se podia vislumbrar a ação de jornais e grupos panfletários na divulgação de ideias libertárias que viriam fundar os movimentos independentistas americanos ${ }^{16}$. Do mesmo modo, no longínquo e semiesquecido Vice-Reino do Rio da Prata, território controlado pelo Império espanhol e elevado à categoria de Vice-Reinado, a mais alta dentro da burocracia colonial espanhola, principalmente para antepor o avanço expansionista português ao longo do século XVIII, os ideais revolucionários também fincaram posição entre a elite colonial, gerando um longo período marcado por guerras internas e instabilidade política.

\subsection{Surgimento das Províncias Unidas do Rio da Prata (1810-1852)}

Em 1810, com as invasões napoleônicas na Europa e o exílio forçado do rei espanhol Fernando VII, súditos da coroa espanhola e do rei exilado presentes em solo americano, desconhecendo a atual coroa e a falta de legitimidade de seus atos, deram início ao longo processo de independência das colônias hispânicas nas Américas, ainda que, a priori, o discurso vigente apontasse na busca de manutenção das posses do

\footnotetext{
${ }^{15}$ Sobre a relação entre mídia, literatura e revolução entre os séculos XVIII e XIX, ver:

DARNTON, Robert. O Grande Massacre de Gatos: e outros episódios da história cultural francesa. São Paulo: Graal, 2011.

Robert. Boemia Literária e Revolução: o submundo das letras no Antigo Regime. São Paulo: Companhia das Letras, 2007.

${ }^{16}$ TERÁN, Oscar. Historia de las ideas en la Argentina: diez lecciones iniciales, 1810-1980. Buenos Aires: Siglo XXI Editores Argentina, 2008, págs. 30-31; VIÑAS, David. Literatura argentina y politica: de los jacobinos porteños a la bohemia anarquista. Buenos Aires: Sudamericana, 1997, pág. 14.
} 
verdadeiro rei, que, uma vez impossibilitado de governar, adiava aos colonos a obrigação de manter suas legítimas posses. ${ }^{17}$

A primeira das colônias a tomar tal atitude foi exatamente aquela que figurou por longa data como o elo mais fraco do extenso Império espanhol no Novo Mundo: o ViceReino do Rio da Prata, constituído à época pelos atuais Uruguai, Paraguai, Bolívia e Argentina ${ }^{18}$. Uma longa discussão sobre o futuro do Vice-Reino se estendeu por décadas a fio, perpassando-se guerras, revoluções e conflitos internos. Muitos historiadores definem a questão territorial como uma das grandes bases da história da região do Rio da Prata no século XIX.

As questões internas que têm marcado a Argentina desde então estão diretamente ligadas a este contexto de conflitos e tramas, além do trauma causado pela desestruturação do Vice-Reino. Em 1811, José Gaspar Rodríguez de Francia proclamou a independência do Paraguai e, em 1828, a província da Cisplatina, ou Banda Oriental, como era chamada no Rio da Prata, tornou-se independente e ganhou o nome de Uruguai. Ambos os fatos são de especial relevância por conta de sua repercussão no cenário político argentino.

Com a separação formal em 1810, se seguiu um estado de anarquia e de detrimento das antigas estruturas coloniais espanholas ${ }^{19}$, favorecendo o aparecimento de milícias armadas compostas por habitantes locais, os gauchos, por sua vez liderados pelos grandes proprietários de terras das províncias do interior, conhecidos por caudilhos ${ }^{20}$.

O que se pode abstrair é exatamente a situação de oposição de interesses imediatos: enquanto a elite comercial do cabildo de Buenos Aires buscava exercer a liderança sobre as demais províncias, estas, por sua vez, a partir de suas elites locais, buscavam a autonomia e uma participação mais efetiva na configuração deste novo Estado.

Desta forma, surgia a raiz das contradições políticas da Argentina moderna: a luta entre os favoráveis pelo unitarismo, sob o controle de Buenos Aires, e os federales, a

\footnotetext{
17 HALPERIN DONGHI, Tulio. Historia Contemporánea de America Latina. Madrid: Ed. Alianza, 2010, p. 97.

${ }^{18}$ BANDEIRA, Moniz. O Expansionismo brasileiro e a formação dos Estados na Bacia do Prata. $3^{\text {a }}$ ed. Brasília: UnB, 1998, p. 43.

19 Donghi denomina de "la larga espera" este período de conturbações, que vai de 1825 a 1850. HALPERIN DONGHI, Idem, p. 135.

${ }^{20}$ Os caudilhos eram grandes proprietários de terras que possuíam um carisma natural para lidar com seus peões, os gauchos, que constituíram suas milícias particulares. Muitos deles marcharam com estas milícias para as batalhas de independência.
} 
favor da manutenção da autonomia das demais províncias. Por conta destas questões o sistema político se viu devastado e caótico, além de envolto em um estado de guerra civil constante entre estas duas facções ideológicas, tendo a situação se estabilizado, de certa forma, apenas com a ascensão do ditador Juan Manuel Rosas, que governou Buenos Aires de 1829 a 1852.

Foram estas correntes políticas, movidas por interesses econômicos e ideologias diferentes, as responsáveis por longas e acaloradas discussões no cenário nacional. A primeira, a unitária, encarnava de forma consensual uma "postura liberal, elitista, centrada en Buenos Aires y en las clases altas cultas que promueven el éxito mediante la imitación de Europa y los Estados Unidos"21. Seu discurso denegria a herança cultural espanhola e a forma "bárbara" de vida rural que os habitantes das províncias do interior levavam. Assim, os defensores desta corrente logo passaram a ser conhecidos simplesmente por liberais, ainda que o termo liberal ${ }^{22}$ aqui constituído em muito difere de sua conceituação clássica.

Em contrapartida, do lado exatamente oposto do discurso liberal, se encontrava, em um primeiro momento, seus opositores federales, que se baseavam em uma visão de privilégio ao passado colonial. Exaltava-se a figura do colonizador espanhol e de seus descendentes diretos, os caudilhos, bem como o habitante autóctone dos pampas, isto é, o gaucho, em detrimento do elemento estrangeiro. Mais tarde, com a defesa da descentralização política e com o protecionismo em torno da mão de obra local, este mesmo pensamento seria devidamente apropriado pelo discurso nativista, inclusive a partir de uma redefinição do gaucho.

\subsection{A unificação argentina (1852-1880)}

O Estado argentino é o produto de uma combinação de fatores internos e externos que fugiram ao controle dos primeiros pais fundadores. Do ponto de vista da situação política interna, o território argentino já a muito vinha sendo marcado por numerosos embates envolvendo as elites provinciais, sobretudo entre as elites portenhas, fadadas a

\footnotetext{
${ }^{21}$ SHUMWAY, Nicolás. La Invención de la Argentina: Historia de una Idea. 2 ed. Buenos Aires: Emecé, 2002, p. 233.

${ }^{22}$ Conforme diz Shumway: "A esta altura debería ser obvio que el uso de las palabras 'liberal' y 'liberalismo' en la Argentina es muy distinto al que se le da en Estados Unidos y Europa Ocidental.” Idem, p. 233.
} 
um cosmopolitismo intrínseco, e as elites interioranas, com raízes culturais coloniais mais latentes do que a de seus próceres. Outrossim, a ação diplomática de outros Estados nacionais, sobretudo do Império do Brasil e do Império Britânico, em relação ao Rio da Prata, marcou o aprofundamento da crise política interna neste período de préconsolidação nacional.

Os anos de 1851 e 1852 foram decisivos para os rumos futuros do Estado argentino, pois foi neste período que o governo de Juan Manuel Rosas, o temível caudilho de Buenos Aires, sofreu sua maior resistência armada em praticamente duas décadas de governo. Foi Justo J. de Urquiza, um histórico e influente caudilho da província de Entre Ríos, o responsável pelo levante de armas ante o despotismo praticado pelo governo rosista.

Urquiza representava não só a liderança de uma gigantesca parcela de caudilhos e populares descontentes com os rumos tomados pelas Províncias Unidas do Rio da Prata nos últimos 20 anos, como também se fazia ponta de lança de uma intricada rede de interesses estrangeiros referentes à troca do governo vigente. Em especial, destaca-se a intensa atuação da diplomacia brasileira e britânica, juntamente a políticos uruguaios, no favorecimento dos interesses das elites descontentes com o governo de Rosas. Como diz Beatriz Bosch:

\begin{abstract}
Resuelto ya en 1850 a lanzar la transcendental empresa, Urquiza se vale de insospechados emisarios cerca de los dirigentes de la Defensa de Montevidéu y de la diplomacia brasileña. Eran sus necesarios aliados. Pese a contar con un poderoso e disciplinado ejército, carecía de una escuadra para custodia de los ríos. ${ }^{23}$
\end{abstract}

Urquiza também encontrou eco para suas reivindicações dentro da própria Buenos Aires. Ali, a anos, diversas parcelas das elites locais, sobretudo as elites ilustradas portenhas, vinham sendo duramente atacadas pelo governo de Rosas. Muitos de seus representantes, sobretudo aqueles mais jovens, recém integrados à vida política portenha, foram exilados em outros países, dada a dura perseguição empreendida pela polícia política de Rosas.

Citam-se, dentre os principais expoentes desta geração de descontentes, as figuras de Domingo Faustino Sarmiento, Juan Maria Gutiérrez, Esteban Echeverría, Vicente F.

\footnotetext{
${ }^{23}$ BOSCH, Beatriz. La organización constitucional. La Confederación Argentina y El Estado de Buenos Aires IN Nueva Historia de la Nación Argentina: La Configuración de la República Independiente (1810c. 1914). Editora Planeta: Buenos Aires. P. 427.
} 
López, Marcos Paz e Juan Bautista Alberdi, dentre outros. Foram eles os protagonistas da conhecida Generación del ' $37^{24}$, que se notabilizou por sua intensa luta em nome de um Estado constitucional que unisse as províncias em torno de um ideal comum: garantir a paz social e a prosperidade econômica e cultural do novo Estado e de seu povo. Esta geração de intelectuais, pertencentes, todos eles, às elites caudilhas de Buenos Aires e do interior, se perpetuou nos embates com o governo rosista por longos anos, o que permitiu que novos protagonistas surgissem em seus anos finais, destacando-se a figura de Bartolomé Mitre, que será trabalhada mais à frente.

Estes intelectuais encontraram na figura de Urquiza a persona ideal para levar adiante a luta contra Rosas e pela instauração de uma Constituição nacional. Muitos deles, como Sarmiento, entraram em contato com diplomatas estrangeiros em busca de apoio para a implementação de seus ideais políticos. O próprio Sarmiento, conhecido por suas críticas à herança caudilhesca tão disseminada na cultura política de seus conterrâneos, estabeleceu contato com representantes diplomáticos brasileiros, britânicos e norteamericanos, durante seu exílio no Chile, para buscar assentar o apoio político necessário para levar a cabo o plano de fortalecimento político de Urquiza. ${ }^{25}$

O principal ponto de diálogo entre Urquiza e esta geração de intelectuais fortemente afeita aos ideais liberais tão em voga no cenário europeu foi a defesa imprescindível do caudilho de Entre Ríos ao projeto constitucional intentado pela intelligentsia portenha. Desta forma, Urquiza logo tratou, nos anos que antecederam os embates militares de 1851-52, de elevar a sua província, da qual era governador, a um status de prosperidade econômica e cultural, isto sem mencionar a tolerância e complacência do mesmo para com os arquirrivais de Rosas, os quais retornaram de seu exílio forçado para morar, sob a proteção de Urquiza, em Entre Ríos.

O destino futuro da história argentina se definiu em 3 de fevereiro de 1852, durante a Batalha de Caseros, onde as tropas lideradas por Urquiza, com respaldo das forças militares brasileiras, derrotaram as tropas de Juan Manuel Rosas, levando à derrocada de seu poderio político. Derrotado em Caseros, Rosas buscou refúgio na casa do Ministro Plenipotenciário britânico, que lhe concedeu abrigo. Pouco depois, Rosas embarcou para a Inglaterra, vivendo ali até o fim de sua vida ${ }^{26}$.

\footnotetext{
${ }^{24}$ SHUMWAY, Idem.

${ }^{25}$ Idem, p. 427.

${ }^{26}$ LUNA, Félix. Breve Historia de los Argentinos. 11 a ed., Buenos Aires: Planeta, 2003, pág. 104.
} 
Derrotado Rosas e destituído o seu governo, era chegada a hora de se reorganizar o governo argentino. Os primeiros meses de reorganização nacional constataram aquilo a que aspiravam os apoiadores de Urquiza: desde o primeiro momento, novas alianças políticas foram firmadas, buscando-se criar um clima político benéfico para a condução dos assuntos internos. Em 31 de maio, os governadores das 14 províncias que constituíam a Confederação Argentina firmaram o "Acordo de San Nicolás", que firmou as prerrogativas para a convocação de um congresso constituinte, bem como tratou de eliminar a aduana única do porto de Buenos Aires e criou para Urquiza o título de Diretor Provisório da Confederação Argentina ${ }^{27}$.

O Acordo de San Nicolás apontava para um rumo a muito latente na verborragia do novo Direto Provisório: destituir das mãos da província de Buenos Aires os rumos da Confederação. Consequência dos atritos políticos originados já na Revolução de Maio, entre unitários e federales, as pretensões de Urquiza e de seus aliados não foram bem recepcionadas pelos deputados portenhos. De pronto, diversos políticos e intelectuais influentes daquela província debateram o que consideravam como um excesso de poder do Diretor Provisório. No entanto, foi em relação à matéria econômica listada naquele acordo que estes representantes portenhos mais se injuriaram, pois consideravam ridícula a simples ideia de se retirar a aduana única do porto de Buenos Aires, antigo imposto consolidado durante o período rosista, e distribuí-la por outras províncias, medida que, de fato, foi implementada pelo Diretor Urquiza.

Com isto, estava definido o quadro de instabilidade política que se alastraria pela próxima década no Estado argentino. Indignado com a resignação portenha, o coronel Hilário Lagos, antigo general dos exércitos de Rosas, atacou a cidade de Buenos Aires, porém foi rechaçado pelas tropas lideradas por Bartolomé Mitre. Sem angariar a vitória sobre a cidade, Lagos decidiu iniciar um sítio em torno desta, o qual perdurou pelos próximos meses. Em 20 de novembro de $1852^{28}$, conforme fora firmado no Acordo, se instalou o congresso constituinte na cidade de Santa Fé, sem a presença de representantes de Buenos Aires. Este congresso foi marcado por ricas e acaloradas discussões em torno do projeto de nação que se queria constituir. Diversos setores ideológicos se viram representados nestas discussões. Muito se debateu, e de início pouco se implementou. Não poucas vezes, foram necessárias intervenções pessoais de Urquiza e de seus aliados mais próximos para se dar encaminhamento ao congresso e à redação da Constituição.

${ }^{27}$ Idem, pág. 110.

${ }^{28}$ BOSCH, Idem, p. 430. 
Finalmente, em 25 de maio de 1853, data da comemoração da Independência das Províncias Unidas, Urquiza promulgou a Constituição nacional, que em seguida foi aclamada pelos representantes das 13 províncias presentes.

Logo após ter sido promulgada, a Constituição foi levada ao conhecimento dos representantes portenhos, que imediatamente a rechaçaram. Apesar da oposição portenha, foi dada continuidade aos trâmites legais firmados e assegurados pela Constituição federal. Urquiza renunciou ao cargo de Diretor Provisório e convocou novas eleições para Presidente e Vice-presidente da República. O próprio Urquiza foi eleito como primeiro Presidente da Confederação Argentina, então instalada na cidade de Paraná, capital da Província de Entre Ríos.

Assim, uma situação pitoresca se desenhou nas paragens argentinas. Virtualmente, dois governos passaram a existir concomitantemente na Argentina: a Confederação Argentina, com sede em Paraná, e o governo de Buenos Aires. Em 11 de abril de 1854, a Sala de Representantes de Buenos Aires sancionou, após um rápido e irregular processo constituinte, uma Constituição da Província, a qual defendia o livre exercício da mesma como um Estado autônomo ${ }^{29}$.

Ao longo dos anos seguintes, em meio à coexistência entre a Confederação Argentina e o Estado de Buenos Aires, diversas vitórias e derrotas se logram de ambos os lados. Em pouco tempo se atenuou a urgência da matéria econômica e diplomática para ambos governos, os quais buscaram solucioná-las prontamente. Do ponto de vista diplomático, ambos Estados divisaram o reconhecimento das grandes nações estrangeiras. Ambos batalharam concomitantemente pelo estabelecimento de relações diplomáticas com a Inglaterra e França, os quais trataram de agir de modo neutro, ainda que com interesses claros em relação aos dois governos.

No entanto, foi na parte econômica que a diferença entre os dois se tornou latente. Graças ao porto de Buenos Aires, com sua vazão para o Rio da Prata e o intenso fluxo de embarcações e mercadorias, o Governo de Buenos Aires, definitivamente, estava na frente na corrida por capital externo. Sua aduana garantia um intenso desenvolvimento da cidade e de sua economia, entretanto, a Confederação argentina possuía grande dificuldade em atrair investimentos estrangeiros, sobretudo pela escassez de contatos do mundo financeiro. Apenas o Barão de Mauá, famoso banqueiro brasileiro, decidiu investir capitais dentro da Confederação, a partir da criação de um banco em Rosário ${ }^{30}$.

\footnotetext{
${ }^{29}$ Idem, p. 432.
}

${ }^{30}$ Idem, p. 443. 
Essa situação se desenlaçou até o ano de 1860, quando, após um período de armistício entre os dois governos, os embates bélicos voltam a atingir grandes proporções. Neste ano, após ter chegado ao fim o seu mandato presidencial, Urquiza foi eleito governador da província de Entre Ríos, enquanto Bartolomé Mitre tornou-se o novo governador da província de Buenos Aires. Ambos governadores possuíam renomada reputação política e militar em suas províncias locais, o que facilita entender o motivo de ambos se tornarem não só representantes políticos máximos de suas províncias, como também os generais principais de seus exércitos provinciais.

Por um curto tempo, na ocasião de uma breve derrota militar sofrida por Mitre na Batalha de Cepeda, ambos generais estabeleceram contato em prol de uma conciliação militar. No entanto, após uma repressão infeliz feita pelas tropas federais a partir de um motim liderado pelo caudilho Antonino Aberastain na província de San Juan, que levou a sua execução quando já se encontrava preso, os dois governadores acabaram por quebrar a trégua e voltar às armas.

Desta vez, o general Mitre assumiu a posição de comando e venceu a maior parte das batalhas travadas contra as tropas federais chefiadas por Urquiza. A maior e mais decisiva de suas vitórias foi durante a Batalha de Pavón, onde mais de trinta mil homens se enfrentaram. As forças de Mitre mostraram-se mais eficientes, o que forçou a retirada de Urquiza do campo de batalha. Em janeiro de 1862, passados quatro meses, em meio ao caos político que se alastrava pelas províncias, e que tendia a piorar caso não se chegasse a uma solução, Justo J. de Urquiza decidiu abaixar as armas e aceitar uma trégua negociada com Buenos Aires.

Mitre, retornando ao papel de governador de Buenos Aires, pressionou os representantes das treze províncias a reorganizarem a nação sob a égide portenha. Consumidos pela derrota, os representantes eleitos decidiram permitir que Mitre convocasse um novo Congresso, além de delegarem a ele os poderes de chefe nacional provisório. Após uma década de ostracismo, Buenos Aires voltaria a ser protagonista do poder nacional.

\subsection{O Roquismo e a égide do Estado argentino moderno (1880-1890)}

Entre 1862 e 1880, os rumos políticos adotados pelos grupos governantes da Argentina foram uma consequência do desenrolar dos acontecimentos ligados à Batalha 
de Pavón, onde o general Bartolomé Mitre angariou a vitória política de Buenos Aires como protagonista do futuro político argentino. Nestas duas décadas, a província portenha assumiu o posto de liderança do Estado argentino, e três de seus mais ilustres habitantes foram eleitos Presidentes da República, respectivamente: Bartolomé Mitre, Domingo Faustino Sarmiento e Nicolás Avellaneda. No entanto, estes governos precisaram lidar com diversas insurreições caudilhescas nas províncias interioranas, no que recorreram à ação enérgica em busca da tão ansiada paz social prometida em Pavón. Nesse momento de contenção das rebeliões, algumas novas figuras ascenderam na política nacional, dentre elas aquela que viria a abrir um novo e definitivo horizonte de prosperidade econômica para a Argentina: Julio Argentino Roca.

A Batalha de Pavón em 1862, e o subsequente período de trégua em nome da unificação nacional, não puseram fim à velha disputa entre unitaristas e federalistas. $\mathrm{Na}$ prática, a proposta unitária, centrada em Buenos Aires como a protagonista natural da política nacional, atingira seu apogeu neste período. Não obstante, a tradição federalista permaneceu insepulta, sobretudo nas províncias interioranas, por ainda muitos anos, os quais foram palco de diversas rebeliões lideradas por caudilhos contrários à hegemonia portenha. Outrossim, às rebeliões federalistas se somaram um conjunto de enfrentamentos políticos entre os principais nomes da política nacional, como em 1874, quando o próprio Mitre, então ex-presidente da República, liderou uma rebelião armada contra a posse de Avellaneda na Presidência da República, a qual foi sufocada pela rápida e incisiva ação do exército nacional ${ }^{31}$.

Nos bastidores destes enfrentamentos militares, resultantes da falta de alianças políticas capazes de coadunar as lideranças políticas em torno de um projeto nacional em comum, se desenrolou o surgimento de um novo partido político que empreenderia as maiores e mais significativas reformas estruturais que o Estado argentino havia conhecido até então. Em 1874, durante as campanhas eleitorais presidenciais que elegeram Nicolás Avellaneda, surgiu, oriundo de uma união entre os então conhecidos Partido Autonomista e Partido Nacional, o Partido Autonomista Nacional. Foi o PAN o principal protagonista da política nacional entre os anos de 1874 a 1910, configurando o que parte da

${ }^{31}$ GALLO, La consolidación del Estado y La reforma política (1880-1914) IN Nueva Historia de la Nación Argentina: La Configuración de la República Independiente (1810-c. 1914). Editora Planeta: Buenos Aires, p. 512. 
historiografia argentina costuma chamar de "República autonomista", ou ainda, "República oligárquica"32.

A origem da ascensão e hegemonia do PAN está intimamente ligada ao ambiente de caos e instabilidade política que se assistiu ao longo da década de 1870. Julio Argentino Roca, natural da província de Tucumán, foi um proeminente oficial do exército nacional argentino que começou sua carreira lutando em Pavón e na Guerra do Paraguai, na qual demonstrou grande habilidade militar e começou a ascender nos auspícios de determinados caudilhos políticos. A grande façanha militar, no entanto, que lhe rendeu um lugar entre os "ilustres", foi a vitória sobre as milícias rebeladas encabeçadas pelo caudilho López Jordán de Entre Ríos. A rebelião de Jordán tinha como alvo a presidência de Domingo Faustino Sarmiento, o qual mobilizou as tropas federais para conter as milícias jordanistas ${ }^{33}$. Foi Roca o responsável pelo ataque às tropas de Jordán, e sua vitória foi tamanha que Sarmiento o elevou ao posto de coronel, em gratidão pelo seu desempenho em nome da segurança nacional. ${ }^{34}$

Em 1877, após a morte de seu rival político Adolfo Alsina, fundador do Partido Autonomista de Buenos Aires, então ministro de Guerra, Roca assumiu o cargo deixado vago pela morte de seu antecessor. O governo era então ocupado por Nicolás Avellaneda, pertencente ao recém-criado Partido Autonomista Nacional, o qual surgiu da aliança Avellaneda-Alsina em 1874. Roca caíra nas graças de Avellaneda graças ao seu gênio político e tenaz capacidade de criar alianças políticas e militares eficazes, e por essa razão foi conduzido ao cargo de Ministro da Guerra e da Marinha em 1877.

A chegada ao renomado Ministério da Guerra propiciou à Roca os recursos necessários para pôr em andamento alguns de seus antigos projetos pessoais. Em 1878, Roca, com a autorização do presidente Avellaneda, levou ao Congresso argentino um projeto de lei que buscava a autorização, bem como os recursos necessários, para levar a

\footnotetext{
${ }^{32} \mathrm{~A}$ historiografia sobre este período é bastante rica e diversificada, resultando em poucas variações teóricas sobre a substância principal deste momento político, isto é, independentemente de se chamar este momento de "República Oligárquica", "República Autonomista" ou ainda de "República liberal-conservadora", os historiadores argentinos são quase que unânimes em afirmar que este foi o período de definição das bases políticas, econômicas e culturais da Argentina, em que uma série de complexas alianças envolvendo as principais elites nacionais tomou forma e garantiu, por meio do controle eleitoral e social por parte destas, um período de grande prosperidade econômica e social para a nação argentina. Não obstante, o efeito colateral resultante do controle social feito à "mão de ferro" por parte dos políticos autonomistas foi o surgimento de grupos revolucionários oriundos, sobretudo, das classes médias urbanas e dos grupos de imigrantes recém-chegados ao país, que trouxeram novos e enérgicos debates ao seio político nacional, que se desenrolaram pelas décadas de 1910 e 20, alvo de análise desse trabalho.

${ }^{33}$ LUNA, Félix. Historia integral de la Argentina - los años de prosperidade. Buenos Aires: Editorial Planeta Argentina, 1997, pag. 12.

${ }^{34}$ Idem.
} 
cabo a expansão territorial argentina rumo à Patagônia, o que resultaria, necessariamente, em pesados confrontos militares contra as populações indígenas que habitavam toda aquela imensa região de pampa. Roca defendia que o domínio desta ampla região era uma questão de segurança nacional, pois acreditava que, caso os Argentinos não viessem a tomar uma atitude rápida, em pouco tempo o Chile invadiria e anexaria a Patagônia ao seu território ${ }^{35}$.

O projeto foi aprovado e posto imediatamente em prática por Roca, que pessoalmente liderou suas tropas na marcha para o Sul. As tropas nacionais, fortemente armadas e treinadas, entraram em numerosos conflitos com as tribos da Patagônia, sobretudo da etnia Mapuche, e em pouco tempo, já em 1879, a vitória de Roca já estava assegurada. Estima-se que a guerra de anexação da Patagônia tenha custado a vida de milhares de indígenas.

Terminada a Presidência de Avellaneda, foi convocado um novo pleito eleitoral, do qual saíra vitorioso o general Julio A. Roca, que assumiu o posto no ano de 1880 . Roca provavelmente foi o mais influente político argentino a ocupar o posto de presidente da República desde Mitre até Yrigoyen, em 1916, graças aos êxitos logrados em suas duas presidências à frente da Argentina. Durante seus anos de governo, Roca estimulou a produção agroexportadora, que logo se tornou a coluna vertebral da economia nacional, estimulou as grandes reformas urbanas, sobretudo em Buenos Aires, financiou, junto a bancos estrangeiros, a expansão da malha ferroviária argentina, bem como de toda a sua estrutura de transportes, além de ter dado um imenso impulso na atração de imigrantes para as indústrias locais ${ }^{36}$.

Outra importante medida tomada pelo presidente Roca no início de seu primeiro governo veio de encontro a um histórico problema nacional, cerne de tantas revoltas e guerras ao longo de décadas: a situação da província de Buenos Aires como capital federal. A principal causa que levou Roca a pensar na criação de uma capital definitiva para o governo nacional, desatrelada do governo da província de Buenos Aires e dos interesses de seus políticos históricos, foi a questão da aduana federal, então centralizada na província portenha e em seu porto no rio da prata. A rica aduana ficava quase que

\footnotetext{
${ }^{35}$ Idem, p. 14.

${ }^{36}$ OSZLAK, Oscar. Reflexiones sobre la formación del Estado y la construcción de la sociedad argentina. Desarrollo Económico, Vol. 21, $\mathrm{N}^{\circ}$ 84, 1982, pp. 531-548. Disponível em: http://www.jstor.org/stable/3466613?seq=1\#page_scan tab_contents. Acesso em: 08 setembro 2014, pág. 16.
} 
completamente sob o controle de Buenos Aires, o que repercutia, já por muitos anos, em acaloradas críticas contra o poder portenho.

A saída encontrada pelo presidente Roca foi a federalização da cidade de Buenos Aires e a construção da nova capital do governo nas imediações da cidade. Roca dava um claro sinal aos seus opositores de que não iria pestanejar em sua missão de subordinar os interesses provinciais ao interesse comum da nação, sobretudo porque as medidas que tinha em mente, voltadas para a expansão do território e para o desenvolvimento econômico dependiam de um ambiente político e social estável. A federalização de Buenos Aires vinha de encontro com este objetivo, pois buscava pôr fim à histórica disputa perpetrada por esta cidade para com o governo central em torno da hegemonia política nacional.

Outra medida tomada por Roca em seu início de governo foi a extinção das milícias provincianas e a consequente monopolização da força pública por parte do governo central ${ }^{37}$. Assim, o governo roquista retirava das mãos dos caudilhos interioranos o poder de rebelião de que tanto usufruíram ao longo de todo o período que se estendeu desde a Revolução de Maio até aquele momento. Somada à federalização de Buenos Aires, essa última medida mirava centralizar em um ritmo contínuo o poder de facto nas mãos do governo central, apontando para um federalismo centralista imanente, o que se pode retirar da fala de um dos principais expoentes da Generación del 37’a apoiar o novo regime, Juan Bautista Alberdi: "Dar al gobierno nacional por capital y residência la ciudad de Buenos Aires, es completar el poder que necesita para dejar de ser un poder de nuevo nombre" 38 .

Outro apontamento dessa tendência centralista verificada nos atos do primeiro governo roquista foram as leis de unificação monetária e de territórios nacionais ${ }^{39}$. A primeira lei visava criar um sistema monetário federal, o que na prática proibia as províncias de emitirem dinheiro por própria conta, garantindo assim que apenas o governo federal cuidasse da questão monetária em todo o país. A segunda lei citada tratava dos novos territórios integrados à nação, oriundos das guerras de expansão empreendidas por Roca nos primeiros anos de seu governo, e que conquistaram ao governo federal milhões de novos hectares de terras a serem colonizadas ao sul, na

\footnotetext{
${ }^{37}$ GALLO, Idem, p. 513.

38 ALBERDI Apud Idem.

${ }^{39}$ Respectivamente, Lei $n^{\circ} 1.130$, de 5 de novembro de 1881 (unificação monetária) e a Lei no 1.532 , de 16 de outubro de 1884 (Territórios nacionais).
} 
Patagônia, e a oeste, no Chaco ${ }^{40}$. As duas leis, somadas à lei de federalização de Buenos Aires e de extinção das milícias provincianas, puseram um fim às rebeliões dos caudilhos interioranos e concentraram o poder de ação e administração em torno do poder federal.

Como dito, a partir de 1884 o território original argentino se viu acrescido de uma extensa região de novas terras a serem exploradas e colonizadas. Essas terras, conquistadas por meio das guerras empreendidas entre 1879 e 1884 por Roca, eram então habitadas por populações indígenas que foram, em sua maioria, dizimadas pelo exército federal durante esse período, o que permitiu ao governo roquista chamar as suas guerras de "Conquista do Deserto", criando um artifício retórico puramente ficcional que visava defender que esse território estava inabitado e aberto ao restante da nação. Não obstante isso, a lei de territórios federais foi criada para organizar as novas áreas ocupadas, colocando sua administração a encargo do governo federal, uma vez que essas terras não pertenciam a nenhuma das províncias estabelecidas.

A inserção de territórios tão vastos, aliados a um senso econômico voltado para uma agenda predominantemente agroexportadora, possibilitou ao Estado argentino dar início a um longo período de pujança econômica e social. O governo roquista logo financiou obras e a inserção de técnicas que visavam modernizar a criação e o abate de gado e ovinos, bem como a expansão da produção agrícola, sobretudo de grãos e cereais, rumo à Patagônia. O gado selvagem, até então ainda criado solto pelos pampas, rapidamente foi substituído por novas raças de gado, mais suscetíveis à criação em zonas cercadas e mais ricos em carne. Assim, a Argentina logo se tornaria uma das grandes nações exportadoras de carne e grãos do mundo, o que atraiu fortes investimentos por parte de outras nações em áreas de infraestrutura ainda precárias no país, e fortemente necessárias para o escoamento da produção ${ }^{41}$.

A expansão territorial e o incremento da produção argentina com a entrada de produtos voltados para o mercado externo foram os responsáveis pela imensa onda de investimentos na expansão das linhas férreas em todo o país ${ }^{42}$. A maior parte desses investimentos tinham origem inglesa, o que apenas reforçou a forte presença desse país na economia argentina. Em pouco tempo, a Argentina passaria a ser proprietária de uma das maiores redes ferroviárias das Américas, e sua inserção no mercado estrangeiro estaria assegurada.

\footnotetext{
${ }^{40}$ LUNA, Idem, p. 23.

${ }^{41}$ LUNA, Idem, p. $28-29$.

${ }^{42}$ Idem.
} 
As medidas centralizadoras de Roca também se alastraram para outros campos, como a da educação. Em 8 de julho de 1884, o governo roquista aprovava a lei ${ }^{\circ} 1420$, sobre as obrigações do Estado em relação à educação. Baseada nas ideias defendidas pelo ex-presidente Sarmiento, a lei versava que a educação primária deveria se tornar obrigatória, pública e gradual, dividida em estágios de desenvolvimento e baseada nos princípios laicos. O choque dessa medida, que atentava diretamente contra uma histórica relação de preponderância da Igreja dentro do ensino primário argentino, foi tamanho que, agravado posteriormente com a introdução do matrimônio civil no país, levou ao rompimento das relações diplomáticas com o Vaticano ${ }^{43}$.

Todas essas medidas marcaram profundamente a era roquista e o início da hegemonia do PAN na condução do governo nacional. Em conjunto, visavam atrelar diferentes instâncias de governabilidade em torno da égide de um governo federalista centralizador e condutor da vida pública. Com isso, buscava dirimir as históricas disputas entre as províncias e concentrar o poder de facto nas mãos do governo central. Essas ações estavam em sintonia com uma tendência mundial em fins do século XIX. Como aponta Gallo, esse conjunto de leis e medidas estatais "eran consistentes con un cuerpo de ideas que ganaba adeptos en Europa como consecuencia de los avances de los procesos de unificación nacional en Alemania e Italia (...)el llamado "nacionalismo unificador", ,44.

Em 1886 chegou ao fim o primeiro governo de Julio A. Roca ${ }^{45}$, que logo foi substituído por seu cunhado, o ex-governador da província de Córdoba, Juárez Celman. As eleições que levaram Celman ao poder estiveram envoltas em uma série de escândalos e críticas por parte das facções opositoras, sobretudo em torno da acusação de fraudes eleitorais e acordos espúrios entre as elites governantes, coadunadas em torno da figura de Roca, principal cabo eleitoral de seu cunhado. O governo de Celman foi também marcado pela continuação da centralização de poder em torno do governo federal, o que lhe dava ares pouco democráticos, e por uma grave crise econômica no fim da década de 1880, gerada pela combinação de uma alta especulação em torno da construção de ferrovias e pela irresponsabilidade fiscal do governo federal. Dentre os resultados dessa crise se encontram os levantes populares do início da década de 1890 que ajudaram a ascender uma nova classe política ao poder.

\footnotetext{
${ }^{43}$ LUNA, Idem, p. 68.

${ }^{44}$ GALLO, Idem, p. 514.

${ }^{45}$ Os mandatos presidenciais duravam 6 anos consecutivos não reelegíveis.
} 


\subsection{Da Revolução do Parque à ascensão da União Cívica Radical (1890-1912)}

O ano de 1890 foi marcado por um clima de forte tensão política no meio social argentino. $\mathrm{O}$ fracasso econômico enfrentado pelo governo do presidente Juárez Celman ocasionou múltiplos levantes de cunho popular na capital federal e mesmo em cidades de outras províncias. A principal parcela de manifestantes era composta por estudantes universitários identificados com as classes de trabalhadores urbanos e fortemente opositores do que se alcunhou por "oficialismo", isto é, a ampla rede de alianças políticas firmadas por Roca que mantinham o PAN e seus principais dirigentes políticos no poder à base de fraudes eleitorais e do enclausuramento de grupos políticos discordantes.

Ao longo da década de 1880 os governos autonomistas estabeleceram uma nova fórmula de governabilidade, baseada em um intricado pacto de alianças entre as elites caudilhescas das diversas províncias, que marcou era na história política argentina. Em oposição a este modo de governar, ou ainda em reação à exclusão de uma ou outra liderança política do pacto, uma série de grupos heterogêneos se agruparam, ainda no início do governo Roca, contrariamente às disposições do Presidente da República.

Essa oposição aos governos autonomistas se deu de forma diferente ao longo do período 1880-1914. Na década de 80, a oposição ao governo roquista se baseava, de forma bastante frágil e desconexa, em torno de alguns indivíduos de grande relevância política, porém incapazes de se reunir em grandes grupos opositores, sobretudo por conta da eficácia das ações aliancistas do PAN. Porém, durante a crise econômica que se assistiu em fins dessa década, a oposição principal à hegemonia autonomista passou a se concentrar não mais em indivíduos isolados, como Mitre e um punhado de políticos descontentes, mas sim em grupos bem organizados e atrelados à massa de trabalhadores e imigrantes que compunham as camadas médias argentinas.

Em 1890 o governo de Celman não apresentava bons frutos e a cada dia parecia angariar um número crescente de descontentes que ampliavam continuamente o rol de inimigos políticos de seu governo. Como bem representa o historiador Félix Luna:

Los mitristas lo aborrecían por considerarlo el continuador del régimen que em 1880 los había desplazado definitivamente del poder, y lo acusaban de pervertir el sistema republicano con las intervenciones em Tucumán y Córdoba y con el sistema de "unicato" que prevalecía. Curiosamente, Roca y sus amigos se sentían traicionados por Juárez Celman y denunciaban las ventas de ferrocarriles y la concesión de las obras de salubridad de 
Buenos Aires como actos indignos de un Estado consciente de sus responsabilidades. ${ }^{46}$

A oposição ao governo de Celman, portanto, configurava uma multiplicidade política e ideológica como poucas vezes visto até então. Foi neste contexto que um numeroso grupo de jovens universitários argentinos, atrelados à uma grande parcela de trabalhadores urbanos, muitos dos quais imigrantes, e encabeçados por uma das grandes figuras da política portenha, ascendeu ao palanque político nacional como o germe do primeiro grande partido de base popular da América do Sul.

Em 13 de abril de 1890, velhos e novos representantes da política nacional uniramse em torno da derrubada do governo de Celman e da criação de instituições mais democráticas e transparentes. Foi nesse dia que personalidades como Bartolomé Mitre, o antigo líder autonomista portenho Leandro Alem, o futuro fundador do Partido Socialista argentino Juan B. Justo, bem como outros grandes personagens políticos, tais como Bernardo de Irigoyen e José Manuel de Estrada, organizaram a União Cívica, que foi um grande ajuntamento de civis e militares opositores do regime autonomista de Celman ${ }^{47}$.

A criação da União Cívica foi seguida de uma marcha na Praça de Maio e pela criação de um grupo revolucionário formado por membros civis e, sobretudo, militares, ligados principalmente ao mitrismo. O desenrolar dos dias foi seguido de motins e levantes populares encabeçados pela União, liderada por Leandro Alem ${ }^{48}$ e seus seguidores. A pressão popular sobre o governo fez com que o Presidente buscasse renovar suas velhas alianças, sobretudo com Roca, e apaziguar os ânimos gerais, porém, logo percebeu que sua atitude de renovação era tardia.

Seus aliados políticos o abandonaram e seus ministros, mesmo aqueles que afirmaram fidelidade, se encontravam reticentes com o futuro do governo. O ponto fulminante para o governo foi o anúncio de que o o mesmo deveria quitar, com alguns dias de espaço, uma dívida de meio milhão de libras esterlinas com o governo da Inglaterra, referentes aos contratos das ferrovias ainda não pagos ${ }^{49}$. Tendo em vista a impossibilidade do pagamento, Celman anunciava a 4 de agosto de 1890 sua renúncia ao governo, sendo sucedido por Carlos Pellegrini na Presidência da República.

\footnotetext{
${ }^{46}$ LUNA, Idem, p. 96.

${ }^{47}$ FLORIA, Carlos Alberto; GARCÍA BELSUNCE, César A. Historia de los argentinos. Tomo 2. Ediciones Larousse Argentina, 1992, p. 199.

${ }^{48}$ Idem.

${ }^{49}$ LUNA, Idem, p. 112.
} 
O novo governo teve como principal meta, e dificuldade, a estabilização da economia e do cenário político, ainda conturbado pelas agitações populares e pelo cenário de crise. No entanto, a grande consequência das revoltas de 1890 foi o surgimento do novo grupo de oposição, centrado em torno da União Cívica. A heterogeneidade desse movimento, que unificou personagens pertencentes a esferas ideológicas tão díspares em torno da queda do governo eleito, foi tamanha que, assim é possível colocar, todos os principais protagonistas políticos das décadas seguintes estavam ali reunidos, e em sua absoluta maioria do mesmo lado do front.

Dois dos personagens envolvidos nas revoltas contrárias ao governo de Juárez Celman são figuras centrais a essa pesquisa: Hipólito Yrigoyen e José Félix Uriburu ${ }^{50}$. Foi na casa de Uriburu, então subtenente do exército, que 33 oficiais militares juraram defender o movimento cívico contrário ao governo e à Constituição federal, dando origem às revoltas posteriores. Em um estranho acaso do destino, os ex-aliados viriam a se tornar, décadas após a queda de Celman, em figuras chaves de um dos momentos marcantes da história argentina.

O governo Pellegrini trouxe novas perspectivas de crescimento econômico e progresso material à nação. Ainda que tenha lidado com um tumultuado contexto político, Pellegrini conseguiu estabilizar as relações interpartidárias, buscando assentar o seu governo sobre uma base aliada heterogênea, formada por membros de diferentes castas ideológicas:

Pellegrini tradujo su diagnóstico íntimo de la situación en la formación del gabinete: Roca en el ministério del Interior; Eduardo Costa y José María Gutiérrez-dos mitristas - en los de Relaciones Exteriores y Justicia, Culto e Instrucción Pública, repectivamente; Vicente Fidel López-viejo urquicista vinculado con la Unión Cívica a través de su hijo Lucio, componente de la Junta Revolucionaria del Parque - que significaba el ejército subordinado al poder estabelecido, en el ministerio de Guerra y Marina. Un gobierno de coalición, con predomínio porteño (...) y la presencia del tucumano Roca (...) la incorporación del mitrismo en la estructura de poder del autonomismo nacional, fue uma maniobra habil y la gratificación lógica para una actitud negociadora y reticente respecto de la revolución por parte del líder del mitrismo, que eliminaba una posible oposición y sería premonitora de acuerdos políticos posteriores. ${ }^{51}$

\footnotetext{
${ }^{50}$ FLORIA; GARCÍA BELSUNCE, Idem, p. 208.

${ }^{51}$ Idem, p. 215.
} 
O Presidente Pellegrini, dessa forma, intentou criar um sistema de alianças políticas interpartidárias que lhe garantissem a capacidade de governabilidade e liderança. Outrossim, essas alianças seriam de grande valia no tocante à aprovação, no âmbito do Congresso, de medidas duras que visassem a austeridade econômica, de modo que o Estado argentino conseguisse controlar a alta inflação que assolava o país. No entanto, a economia deteriorou ainda mais nos anos seguintes.

A péssima situação econômica vivida pelo país naquele momento se somou a perda de apoio político por parte das principais facções políticas. Convocadas as eleições, Pellegrini precisou ponderar qual seria seu sucessor, tendo como base a perspectiva de aprofundamento da crise econômica e institucional. Durante as eleições ocorreu uma divisão dentro da União Cívica, o grande partido surgido na Revolução de 1890, entre os apoiadores de Mitre e Roca, favoráveis ao sistema de alianças e acordos políticos, lado do qual se encontrava Pellegrini, e aqueles que apoiavam Leandro N. Alem e Bernardo de Irigoyen para a eleição.

O embate entre as duas facções políticas internas da União Cívica levou à convocação de comícios por ambos os lados, gerando a cisão do grupo em dois diferentes partidos: a União Cívica Nacional, presidida por Bonifacio Lastra, e a histórica União Cívica Radical, liderada por Alem e Irigoyen. As eleições foram acirradas e, após muitas reviravoltas, tal como a desistência de Bartolomé Mitre pela disputa à Presidência do país, a disputa ocorreu entre a fórmula Bernardo de Irigoyen-Juan M. Garro pela União Cívica Radical (UCR) contra Luis Sáenz Peña-José Evaristo Uriburu pela União Cívica Nacional $(\mathrm{UCN}){ }^{52}$ As eleições foram marcadas por comícios agitados e tentativas de boicote, sobretudo por parte da $\mathrm{UCR}^{53}$.

No fim, Pellegrini foi sucedido por Luis Sáenz Peña ${ }^{54}$, presidente da República argentina entre os anos de 1892 e 1895, cujo vice-presidente eleito era José Evaristo Uriburu. Sáenz Peña teve um conturbado início de governo, marcado pela continuidade da crise iniciada em 1890, iniciada pelo pânico gerado entre os investidores norteamericanos, especialmente aqueles diretamente relacionados com o investimento ferroviário, uma das principais áreas em crescimento no território argentino.

\footnotetext{
${ }^{52}$ FLORIA; GARCÍA BELSUNCE, Idem, pág. 220.

${ }^{53} \mathrm{O}$ Presidente Pellegrini chegou ao ponto de mandar deter praticamente todos os líderes radicais durante as eleições, à exceção de Hipólito Yrigoyen.

${ }^{54}$ Luiz Sáenz Peña era pai de Roque Sáenz Peña, futuro presidente da República entre 1910 e 1914.
} 
A crise de 93 foi responsável pela alta do endividamento do Estado argentino e pela crise geral dentre os empresários locais. É necessário recordar que a crise financeira que assolava o país havia se iniciado nos anos imediatamente anteriores, cuja origem se remontava tanto a fatores internos quanto a fatores externos à economia argentina. $\mathrm{O}$ historiador Mario Rapoport assim explicou as origens da crise:

(...) Entre 1886 y 1890, la Argentina tomó prestado, de ese modo, casi 700 millones de pesos oro y el total de su passivo alcanzaba en 1892 a 900 millones de pesos oro. Como la balanza comercial no lograba equilibrarse para hacer frente al servicio de la deuda externa, que llegó a representar cerca del $50 \%$ del valor de las exportaciones, la desconfianza cundió entre los inversionistas extranjeros (...) Los más importantes bancos locales se declararon en bancarrota, en tanto que se acentuo la desvalorización del peso y la cotización de los títulos y acciones de las principales empresas declinaron $(. . .)^{55}$

Tendo de enfrentar uma série de obstáculos políticos decorrentes da situação de crise econômica, Sáenz Peña precisou desenvolver um constante diálogo com as forças de oposição concentradas no Congresso, assim como fizera seu antecessor. No entanto, Saénz Peña se viu diante de um cenário ainda mais caótico do que o de um ano antes, o que dificultou sua aproximação com as bases aliadas, agora divididas em partidos antagônicos. Buscando conciliar radicais, mitristas e autonomistas, Peña primeiramente convidou Irigoyen e Alem a participarem do governo, porém, os mesmos decidiram não aceitar em nome da intransigência partidária. Tendo em vista a negativa dos dois "notáveis" radicias, o presidente convocou para assumir seu gabinete Aristóbulo del Valle, membro da ala moderada da oposição radical, o que exaltou os ânimos da ala mitrista da UCN.

Como se não bastasse a dificuldade em se conseguir criar as alianças necessárias à governabilidade do país, Sáenz Peña precisou lidar com constantes tentativas de sublevação revolucionária nas províncias, todas encabeçadas e arregimentadas pela União Cívica Radical. Somente no ano de 1893, ocorreram três grandes levantes militares radicais, respectivamente, em San Luis, Santa Fe e na própria província de Buenos Aires, esta última em acordo com mitristas descontentes com o ganho de prestígio de del Valle no governo de Sáenz Peña.

\footnotetext{
${ }^{55}$ RAPOPORT, Mario. De Pellegrini a Martínez de Hoz: el modelo liberal.. Buenos Aires: CEAL, 1984,
} p. 15. 
Aristóbulo del Valle chegou a ser convocado pelos radicais intransigentes Alem e Irigoyen a realizar um golpe de Estado por dentro do governo, ao que teria respondido, em um tom nobre e leal "...No doy el golpe de Estado porque soy un hombre de Estado..."56. Del Valle foi pessoalmente a La Plata, centro de onde irradiavam as forças revolucionárias portenhas, para sufocar o movimento a partir de sua origem. Porém, essa tentativa fracassou sobretudo devido à falta de coesão interna do governo em relação ao embate com os radicais e mitristas, principalmente graças à ação de Pellegrini junto à Sáenz Peña, que agiu duplamente com o objetivo de conter a influência crescente de del Valle sobre este. Com a impossibilidade de adotar o seu programa de mudanças, del Valle renunciou, dando lugar a Manuel Quintana, que já havia ocupado o cargo antes dele.

Quintana logo fez uso de uma política de força, baseada no estado de sítio e nas intervenções federais sobre as províncias que estivessem tomadas por revolucionários. Com extremo uso deste método, logo conseguiu prender os principais líderes radicais da ala intransigente, dentre eles Leandro N. Alem. Enquanto isso, foram convocadas novas eleições nas províncias que haviam sofrido a intervenção federal, nas quais ganharam mitristas e autonomistas.

No entanto, essas aparentes vitórias traziam consigo o amargo gosto do desgaste político, da perda de credibilidade do gabinete por parte da população e do enfraquecimento das tênues alianças políticas até então firmadas sobre um telhado de vidro. O estopim da queda do governo se deu quando o Congresso, passando por cima das prerrogativas de Quintana, decidiu aceitar uma intervenção federal em Mendoza, a qual ele era contrário. Quintana então decidiu renunciar ao cargo. O presidente Sáenz Peña, por sua vez, também debilitado pelo cenário de tensão política, chegou ao seu limite logo após a renúncia de Quintana, quando foi fortemente atacado por ter se oposto a inserir, em 1894, um projeto de lei de anistia dos revolucionários presos no fim de 93. Peña, diante das críticas, também renunciou, passando o governo para o seu vicepresidente José Evaristo Uriburu. ${ }^{57}$

O governo de Uriburu durou pouco tempo, e foi marcado pelo acirramento das tensões diplomáticas entre a Argentina e o Chile, que a anos reivindicava parte do território da Patagônia argentina. Os ânimos acirrados entre os governos tendiam a levar ambos países à guerra. Com a debilidade da saúde de Uriburu, Roca, então senador, passou a ditar, com o apoio de Pellegrini, os rumos a serem tomados pelo governo.

\footnotetext{
${ }^{56}$ ALDO DE DÍAZ, Elvira Apud FLORIA, idem, p. 225.

${ }^{57}$ FLORIA, idem, p. 227.
} 
Chegado o fim do governo, Julio Argentino Roca lançou-se novamente como candidato ao governo, com apoio do PAN e da UCN. Logrado êxito, foi eleito para a Presidência em 1898.

O segundo governo de Roca foi marcado por duas características aparentemente antagônicas: por um lado, foi o principal responsável por encontrar saídas possíveis aos impasses políticos e econômicos dos últimos anos, diminuindo o déficit econômico do governo, reestruturando a máquina burocrática e aumentando os investimentos em áreas chaves ao desenvolvimento nacional. No entanto, por outro lado, marcou o início do fim da hegemonia autonomista no governo argentino, com a perda de alianças políticas históricas e o aumento do prestigio da UCR.

O novo governo autonomista também precisou lidar com duas questões de elevada relevância no dia-a-dia dos argentinos, e de grande repercussão nos círculos de poder daquele período: o problema social cada vez mais evidente e a questão internacional, envolvendo a disputa por parcelas da Patagônia argentina com o Chile. Inicialmente, antes que tomasse decisões claras quanto a esses dois problemas, Roca buscou reequilibrar as bases de poder que sustentariam as medidas tomadas pelo seu governo. Sua fórmula de reequilíbrio focava a retomada de prestígio dos "notáveis" na cena política, em uma aliança sólida com mitristas e membros descontentes da UCN.

O segundo governo Roca buscou, arduamente, utilizando-se de uma máquina diplomática invejável, a cargo do renomado diplomata Estanislao Zeballos, pressionar o governo chileno a encontrar um ponto pacífico para as negociações em torno da região disputada. No entanto, com o acirrar dos ânimos por ambas as partes a partir de 1898, a questão entre os dois países foi levada à arbitragem internacional, ainda que tenha demorado alguns anos para se chegar a uma decisão ${ }^{58}$.

Em 1901 as tensões diplomáticas atingiram o seu ápice, levando ambos os países à preparação real para uma possível guerra. Os exércitos argentino e chileno foram mobilizados em massa ao longo deste ano, enquanto a opinião pública e a população civil de ambas nações fomentavam a guerra por meio da retórica nacionalista. Nesse mesmo ano, o governo argentino aprovou a Lei Orgânica do Exército, a qual estabeleceu o serviço militar obrigatório.

Tudo indicava a projeção de uma guerra iminente entre Argentina e Chile, sobretudo graças ao efervescer dos ânimos populares em ambos os países. Porém, graças

\footnotetext{
${ }^{58}$ Idem, p. 234.
} 
à mediação inglesa no conflito, intermediada por forças conciliadoras internas, um acordo de paz começou a se desvelar entre 1891 e 1892, chegando-se assim aos "Pactos de Maio", assinados pelos dois países no outono de 92. Os pactos firmavam o compromisso de ambos governos em aceitar as decisões tomadas pela arbitragem internacional, a qual também seria a responsável por nomear a comissão mista que fixaria os limites entre os dois países na área em litígio.

Findada a querela com os chilenos, foi a vez de Roca mirar suas forças em outras duas questões importantes para as relações internacionais da Argentina autonomista: a definição das fronteiras entre Argentina e Brasil, na região fronteiriça ao estado brasileiro do Rio Grande do Sul, e o reatamento das boas relações diplomáticas com o Vaticano. Ambos objetivos foram conquistados entre 1903 e $1904^{59}$.

A questão social enfrentada por Roca em seu segundo governo era evidenciada por duas características principais: o ganho de poder da União Cívica Radical frente aos grupos populares, encabeçada por Hipólito Yrigoyen, e o aumento de tensão entre as elites econômicas e a população operária, crescentemente aquartelada em torno de grandes organizações sindicais, como a U.G.T, organizada pelos grupos socialistas, e a F.O.R.A, liderada pelos anarquistas ${ }^{60}$.

Porém, a tarefa de lidar com as pautas sociais levantadas pelos grupos acima não coube à Roca. Em 1904, após completado o seu segundo mandato presidencial, foram convocadas novas eleições presidenciais, da quais se fizeram eleitos, com o apoio de Roca, Manuel Quintana para a presidência da República e Figueroa Alcorta para a vicepresidência. O governo de Quintana foi marcado pelo crescimento das tensões entre membros da elite política roquista e mitrista e as lideranças radicais. Em 1905, Hipólito Yrigoyen e os demais membros da liderança radical intentaram, novamente, dar um golpe de Estado e derrubar o governo vigente, por desconhecer a legitimidade da eleição presidencial do ano anterior.

Quintana, no entanto, era um profundo conhecedor das tramas políticas que condicionavam as reiteradas tentativas revolucionárias orquestradas pela U.C.R, as quais

\footnotetext{
${ }^{59}$ Idem, p. 236.

${ }^{60}$ As siglas significam: F.O.R.A (Federação Operária Regional Argentina) e U.G.T (União Geral dos Trabalhadores). Ambas organizações foram fundamentais para a liderança operária na Argentina deste momento, sendo o foco de lideranças socialistas e anarquistas que viriam a dar suporte ao ganho de poder dos radicais no cenário político nos próximos anos. Não por um acaso, grande parte das tentativas de revolução orquestradas pela UCR dentre esses anos tiveram como base de operação os comícios operários de ambas organizações. DE SANTILLÁN, Diego Abad. La F.O.R.A.: Ideologia y Trayectoria del movimiento obrero revolucionario em la Argentina. Buenos Aires: Ediciones HL, 2006, pág. 161.
} 
envolviam a ação interna de membros radicais infiltrados no governo e em suas instituições repressivas, em especial nas polícias de cada província. Por meio de contatos internos, o presidente soube de antemão dos preparativos que levariam a uma revolução instantânea em outras quatro províncias do interior, além da própria capital ${ }^{61}$. Assim, logo se movimentou para antecipar as suas ações as dos revolucionários. Iniciada a tentativa de revolução, o presidente convocou os líderes militares fiéis, dentre eles o próprio José Félix Uriburu, para sufocar os grupos revolucionários encabeçados por Yrigoyen. No fim, a tentativa de golpe por parte dos radicais foi derrotada, com baixas para ambos os lados, e Yrigoyen preso, após se entregar à Justiça.

O governo Quintana prometia a manutenção e ampliação do progresso econômico argentino, no entanto, demonstrava pouca habilidade na resolução dos impasses sociais que prometiam tornar ainda mais instável a segurança nacional. A U.C.R permanecia intransigente em sua ação política, negando-se veementemente a buscar conciliação com outros partidos. Seus membros constantemente buscavam derrubar o regime vigente por meio da força, e sempre que derrotados forçavam, por meio de pressão popular, o governo à concessão de indulto aos envolvidos na irrupção revolucionária. $\mathrm{O}$ ciclo vicioso de revoluções radicais seguidas de indultos e perdão aos revolucionários presos começava a ser verificada pelos membros mais jovens das elites políticas, os quais percebiam que, enquanto os impasses centrais não fossem definitivamente resolvidos, a instabilidade política continuaria a ser imperante.

Em 12 de março de 1906, durante seu segundo ano de governo, Manuel Quintana veio a falecer. Foi sucedido por seu vice-presidente Figueroa Alcorta, um membro próximo aos grupos mais jovens, sobretudo aqueles fiéis às ideias de Roque Sáenz Peña. Durante o seu mandato, que durou até 1910, Alcorta vivenciou o lento e gradual esfacelamento das bases do regime autonomista. Em 1906, faleceram alguns dos mais importantes personagens políticos da Argentina moderna, tanto da base governista quanto da oposição radical: além do próprio Manuel Quintana, faleceram Bartolomé Mitre, Carlos Pellegrini, Francisco Uriburu e Bernardo de Irigoyen $^{62}$.

Durante o período Quintana-Alcorta, houve um grande salto na produção agropecuária de exportação e no desenvolvimento industrial, sobretudo na cidade de Buenos Aires. O principal motivo para o sucesso da primeira foi a abertura, iniciada duas

\footnotetext{
${ }^{61}$ A conspiração radical ocorreu nas províncias de Córdoba, Mendoza, Rosario e Bahía Blanca, além de Buenos Aires capital.

${ }^{62}$ Idem, p. 248.
} 
décadas antes pelo primeiro mandato de Roca, e consolidação de milhões de novos hectares de terras cultiváveis na região da Patagônia, enquanto a produção industrial cresceu enormemente em face ao acúmulo de capitais verificados graças ao controle inflacionário da economia nacional, à renegociação da dívida externa, o que assegurou investimentos estrangeiros em áreas do setor produtivo, e à valorização da moeda argentina no exterior, sobretudo por conta da boa política externa então em curso.

Todas essas características foram fruto do segundo governo Roca, responsável pela estabilização econômica e pelo fortalecimento da diplomacia argentina. Não obstante, um outro fator instigou e alimentou o crescimento econômico argentino, bem como a crescente tensão social verificada: a imigração em massa de estrangeiros. Fomentada por Quintana e elevada ao status de prioridade nacional por Alcorta, a política imigratória conheceu um imenso impulso durante a primeira década do novo século:

Entre 1904 y 1913 la población argentina viose aumentada por un millión y médio de europeos. El censo de 1914 mostró una Argentina de 8.000.000 de habitantes, de los cuales la tercera parte había nacido en el extranjero. La Argentina moderna estaba, pues, en plena evolución política, económica y social. ${ }^{63}$

A elevada taxa de estrangeiros, sobretudo em meio à população operária e engajada ideologicamente, era necessária para o abastecimento da mão de obra da grande indústria então em desenvolvimento, no entanto, tornou-se o foco, e, por conseguinte, o grande alvo da crítica das elites políticas, de grandes greves e paralisações sindicais, sempre envoltas de excessos por parte dos manifestantes e grevistas e da truculência e violência por parte das forças do Estado.

Desde o segundo governo roquista, o Estado argentino buscou tutelar a condução dos problemas sociais vivenciados na Argentina, segundo a visão dessas elites políticas. Ainda com o presidente Roca, duas medidas foram tomadas nesse sentido. Primeiramente com o envio ao Congresso do projeto de criação de um Código de trabalho inédito para o continente naquele período, que visava reestabelecer as relações entre empregadores e empregados, criar direitos para o trabalhador e estabelecer regras para as reivindicações sindicais. Em segundo, com a aprovação da chamada Lei de Residência em 1902, que permitia ao Poder Executivo expulsar, sem necessidade de ação judicial prévia ou mesmo

\footnotetext{
${ }^{63}$ Idem, p. 243.
} 
de ações judiciais existentes, qualquer estrangeiro considerado perigoso para a segurança nacional ${ }^{64}$. Enquanto a Lei de Residência foi aprovada com certa facilidade no Congresso, o projeto de criação do Código de Trabalho foi barrado por conta de disputas internas entre as facções políticas e os grupos representativos dos interesses sindicais.

Durante o mandato de Figueroa Alcorta, as negociações entre Estado, forças sindicais, grupos de imigrantes e líderes radicais foram entravadas pela ação intransigente de grupos políticos contrários à mudança do status quo do regime vigente desde 1880 . No entanto, o desaparecimento do cenário político de velhos membros das elites políticas e o aparecimento de novas lideranças possibilitou a abertura de um canal de diálogo, nem sempre pacífico, entre esses grupos a partir dos últimos anos do governo de Alcorta.

O ano de 1910 foi enérgico nesse sentido. O ano das comemorações do Centenário da Revolução de Maio foi pintado de fortes emoções cívicas. Dois eventos principais eram aguardados neste ano: as eleições presidenciais e os grandes festejos pelo Centenário da Independência argentina. A eleição presidencial foi marcada, novamente, pelos embates ferozes dos grupos opositores.

Três partidos dividiram a cena: a União Cívica Radical, a União Nacional e a União Cívica. Os radicais logo se abstiveram de participar das eleições, devido à recusa do presidente Alcorta de levar a cabo uma reforma eleitoral proposta pelo partido devido ao curto prazo para deliberações. A disputa se deu então em torno de nacionais e cívicos, na qual venceu o candidato nacional, em meio às denúncias de fraudes por parte dos cívicos.

O novo presidente era Roque Sáenz Peña, o mesmo que anos antes fora impossibilitado por Roca de concorrer à Presidência da República, devido às suas visões tidas como "modernistas". Sáenz Peña foi eleito presidente da República em 1910, e sua chegada ao poder marcou o fim da era de hegemonia autonomista e o sepultamento da política de notáveis até então praticada.

O principal problema que despontava ao novo governo era a questão eleitoral, tão debatida nos anos anteriores pelos novos partidos políticos. A União Cívica Radical, sob a liderança de Yrigoyen, a todo instante soava a sirene revolucionária, exigindo rápidas transformações na política nacional. As velhas lideranças nacionais não haviam conseguido conter com eficácia o avanço radical entre os grupos populares majoritários, e nem sequer criado canais de comunicação e negociação com o radicalismo.

\footnotetext{
${ }^{64}$ GALLO, Idem, p. 534.
} 
Sáenz Peña se qualificava ao cargo de pacificador, devido a sua aguçada inteligência e elevada capacidade estratégica. Ele constatava que a nação não suportaria por mais tempo a falta de transparência e participação eleitoral, sobretudo por conta da chegada maciça de imigrantes ao país, os quais eram cooptados, quase em sua maioria, pelos radicais ou pelos socialistas ${ }^{65}$. Era necessária uma reforma eleitoral.

A Reforma Eleitoral se deu por meio de três projetos de lei apresentados pelo Poder Executivo ao Congresso nacional ${ }^{66}$. O Primeiro projeto tratava da lista geral de votantes, isto é, dos cidadãos que poderiam concorrer a cargos políticos. Até aquele momento, a produção da lista cabia, constitucionalmente, ao Poder Executivo Federal, o que acarretava em lutas políticas engendradas à escolha dos votantes. O projeto enviado ao Congresso previa que a produção da lista seria transmitida ao Poder Judiciário, retirando do Executivo a prerrogativa constitucional.

O segundo projeto também dizia respeito ao trâmite eleitoral. Ele definia que o dever de preparo e fiscalização do processo eleitoral em todo o país, até então também a cargo do Executivo, seria igualmente trasmitido ao Judiciário. Por fim, um terceiro projeto de lei findava o esforço reformador. Este foi o mais importante dos três, pois previa o sufrágio universal masculino e a mudança para eleições por lista indireta, o que dava maior capacidade de representação eleitoral aos grupos politicamente minoritários.

Os três projetos, após meses de acaloradas discussões, acabaram por serem aprovados tanto na Câmara dos deputados quanto no Senado Nacional, em grande parte devido à influência do presidente e de seus ministros durante todo o processo de votação nas casas parlamentares. O projeto também foi muito bem recebido pelos grupos populares, o que elevou a popularidade do presidente. A implementação da lei eleitoral de 1912 foi gradual e difícil. As primeiras eleições a adotarem o novo sistema eleitoral ocorreram em 1914, e determinaram nas urnas a ampla majoritaridade da base radical. Contudo, foi em 1916 que a União Cívica Radical atingiu a sua apoteose, com a sonhada vitória presidencial de Hipólito Yrigoyen.

A Lei Eleitoral criada pelo presidente Sáenz Peña foi amplamente debatida por seus contemporâneos. Opiniões favoráveis e contrárias à reforma rapidamente tomaram conta dos meios políticos e intelecutais. Em meio às elites políticas estabelecidas, a voraz

\footnotetext{
${ }^{65}$ ANGel CÁRCANO, Miguel. Saenz Peña: la revolucion por los comicios. Biblioteca Argentina de Historia y Politica. Buenos Aires: Hyspamérica Ediciones Argentina, 1986, pág. 157.

${ }^{66}$ Idem, págs. 160-161.
} 
crítica ao presidente contrastou o apoio popular ${ }^{67}$. No entanto, verifica-se que foi graças a atitude de Peña que a Argentina conseguiu se ver livre de uma revolução popular, elevando as camadas populares ao palanque político por meios democráticos. Contudo, é graças também à lei de 1912 que a cultura política nacional sofreu bruscas transformações, gerando feridas políticas que levariam anos para serem remediadas.

\footnotetext{
${ }^{67}$ Idem, pág. 173.
} 
2. Imprensa argentina e período radical (1916-1928)

\subsection{Entre palácios e barricadas: uma breve história de Bartolomé Mitre e do jornal La Nación}

Em 4 de janeiro de 1870, nas primeiras horas do raiar do dia, chegava às ruas de Buenos Aires as primeiras cópias do jornal La Nación. Fundado por D. Bartolomé Mitre, ex-presidente da República recém-unificada da Argentina, sobre as bases do antigo, e combatente, jornal La Nación Argentina, o La Nación, com suas primeiras mil tiragens diárias, dominaria pelas próximas décadas os bastidores políticos da nova nação. ${ }^{68}$

Bartolomé Mitre buscou fazer de seu jornal o reflexo do futuro que ele próprio anseava à Argentina: um jornal elegante e ao mesmo tempo com posições políticas claras, ideologicamente baseado segundo as premissas liberais-democráticas de seu tempo, balizadoras do estado de direito e da defesa inquestionável das liberdades individuais e de um Estado garantidor do bem-estar do cidadão argentino. Não obstante, o jornal também seria o reflexo das próprias ideologias pessoais de Mitre, bem como o seu portavoz para a sociedade argentina.

O passado político de Mitre, já delineado ao longo do primeiro capítulo deste trabalho, denunciava as posições por ele assumidas no La Nación. Ele próprio fora um homem de posições políticas e ideológicas bastante claras e audazes, chegando mesmo a defendê-las com o punho de sua espada, não obstante a sua preferência pela pena da caneta. Fora um jovem intelectual engajado em torno da causa unitarista, que buscou centralizar o poder de facto nas mãos da cidade de Buenos Aires. Também foi um audaz militar, tendo liderado as tropas portenhas ante as forças federalistas de Urquiza nos anos de entrechoque com a Confederação Argentin. Por fim, reunira todos esses talentos e virtudes pessoais à frente da presidência da república, logo após a unificação em 1862 e a vitória dos interesses portenhos, por ele tão alentados e defendidos. ${ }^{69}$

\footnotetext{
${ }^{68}$ BELTRAN, Oscar R. Historia del Periodismo Argentino. Buenos Aires: Sopena Argentina, 1943, p. 261.

${ }^{69}$ DE MARCO, Miguel Ángel. Bartolomé Mitre: Biografía. Buenos Aires: Editorial Planeta Argentina, 1998, pág. 209.
} 
Como presidente, assentou as bases da nova república, agora unificada sob a égide de Buenos aires. Promoveu as primeiras políticas de centralização administrativa e burocrática do Estado argentino, conteve militarmente as últimas facções federalistas atuantes no interior do país, reformulou e investiu no desenvolvimento do exército nacional, que deveria ser a face de uma nação unificada em torno dos mesmos interesses, e se empenhou em garantir o progresso econômico e cultural argentino, o qual seria plenamente alavancado sob a era autonomista e a liderança de Roca, seu arquirrival.

Coube a Mitre declarar guerra contra o Paraguai do ditador Solano López, juntamente com o Império do Brasil e o Uruguai, formando assim a Tríplice Aliança, a qual sairia vencedora desse que foi o maior conflito armado das américas no século XIX depois da guerra de secessão estadunidense. No entanto, a guerra do Paraguai, e ainda mais os conflitos internos contra os federalistas restantes, consumiram as suas ações à frente da presidência, sendo posteriormente substituído por Sarmiento.

Não bastasse as qualidades acima descritas, representativas daquilo que se poderia esperar da virtú de um líder político sul-americano do século XIX, Mitre ainda reunia mais uma qualidade exemplar ao seu rol de virtudes: a grande eloquência intelectual que o habilitava como um “homme de lettres", um virtuoso intelectual de sua época, autor de um fabuloso conjunto de obras que ainda ajudam a traçar parte significante da história argentina.

Fora, ainda, um habilidoso tradutor de clássicos da literatura universal, tais como a Eneida de Virgílio e a Divina Comédia de Dante Alighieri, dentre tantas outras ${ }^{70}$. Político voraz, general audaz e intelectual virtuoso, pode-se, seguramente, dizer que poucos homens ou mulheres na história recente reuniram, ao mesmo tempo e de modo tão exemplar, tantas demonstrações de preparo e dedicação à vida pública e ao conhecimento humano.

Outrossim, foi à frente do La Nación, a partir de 1870, ano do término da Guerra do Paraguai, que Mitre desempenhou algumas de suas principais façanhas públicas. Sua dedicação ao diário se dava em tempo quase integral, dividindo-o apenas com suas novas funções como senador da república ${ }^{71}$. No entanto, essas ocupações não eram suficientes a ponto de apaziguar o seu intrépido e engajado espírito político. Engajou-se, tanto na função de senador, quanto como editor do La Nación, na oposição política.

\footnotetext{
${ }^{70}$ Idem, pág. 200.

${ }^{71}$ Bartolomé Mitre assumiu o cargo de senador no ano de 1869. Idem, pág. 377.
} 
O surgimento do jornal se deu em meio a um cenário convidativo à cultura letrada portenha. Estima-se que em 1870, segundo o Censo Nacional daquele ano, a população argentina fosse de aproximadamente 1.877.000 habitantes, e destes, somente em Buenos Aires, cerca de 60 mil pessoas, quase um terço da população portenha deste período, sabia ler e escrever ${ }^{72}$. Apenas um ano antes, em 1869, havia surgido o jornal La Prensa, pertencente a José Clemente Paz, cujo objetivo principal era diferir da forte polarização política que marcou os periódicos argentinos até aquele momento, por meio de posicionamentos claros ${ }^{73}$. O La Nación surgiu com a mesma premissa, e não por um acaso tinha como axioma fundacional os seguintes dizeres: "La Nación será una tribuna de doctrina",74.

Mitre fundou o seu jornal a 4 de janeiro de 1870, a partir de um capital equivalente a 800.000 pesos da época, levantado com a ajuda de outros nove amigos ${ }^{75}$. O jornal surgiu sobre as bases do antigo La Nación Argentina, no qual publicara artigos políticos por anos, e do La Tribuna. Ambos jornais serviram, em seu tempo, às rivalidades políticas que dominaram o país antes da unificação de 1862. Na nova Argentina, pensava Mitre, não cabia mais este tipo de imprensa, que, no entanto, havia empreendido "honráveis" esforços na consolidação nacional. Para ele, a nova imprensa deveria se pautar, tal como no exemplo do seu rival La Prensa, no discernimento ideológico e na propagação de um ideal cívico e nacional. Mitre resumiu o seu pensamento na seguinte sentença: " $L a$ Nación Argentina fue una lucha. La Nación será una propaganda"76.

De fato, ao longo de suas décadas de existência, que se prolonga com grande sucesso até a atualidade, o jornal buscou participar de modo ativo dos rumos políticos adotados pelos diferentes governos argentinos. Seu lema deixava claro a todos os leitores que aquele jornal não iria se eximir de seu dever público de informar, opinar e se posicionar sempre que a necessidade assim o exigisse.

A essência fundamental seguida pelo jornal em sua longa jornada primou-se pela defesa do liberalismo econômico, pauta concebida por Mitre desde os seus primórdios

\footnotetext{
${ }^{72}$ Os dados foram coletados pelo historiador da imprensa argentina Carlos Ulanowski In Ulanovsky, Carlos. Paren las rotativas: una historia de grandes diarios, revistas y periodistas argentinos. Buenos Aires: Espasa Calpe, 1997, pág. 04.

${ }^{73}$ Idem.

${ }^{74}$ Idem, pág. 05

75 Os outros nove companheiros de Mitre na criação do La Nación foram: José María Gutiérrez, Rufino, Francisco de Elizalde, Juan Agustín García, Delfín B. Huergo, Cándido Galván, Anacarsis Lanús, Adriano Rossi e Ambrosio Lezica.

${ }^{76}$ O termo "propaganda" aqui colocado denota o esforço "civilizador" do novo periódico, com seu objetivo magno de consolidar a nascente nação argentina sonhada pelos atores políticos reinantes a partir de 1862.
} 
políticos, e pelo pluralismo político como forma de manutenção dos interesses públicos e da transparência no trato com as instituições republicanas, pontos tão arduamente defendidos pelo mesmo em vida.

O jornal fundou uma nova forma de se fazer imprensa no país, com enviados especiais a outros países, contato constante com agências internacionais, sobretudo no velho mundo, e o uso de propagandas empresariais nas páginas do periódico, tanto como propaganda, quanto como fonte de recursos ${ }^{77}$. Sua atitude inovadora logo se espalhou pelo país e formou "discípulos" em diversas províncias. É possível afirmar que o impulso final para a popularização dos meios de comunicação de massas na Argentina tenha sido obra, em grande parte, do La Nación. ${ }^{78}$

Em 1874, quando do término do mandato presidencial de Sarmiento, Mitre decidiu voltar a concorrer à presidência da república pelo Partido Nacionalista, porém, foi derrotado pelo candidato opositor Nicolás Avellaneda. Acusando-o de fraude eleitoral, Mitre reuniu forças militares aliadas e marchou contra as tropas nacionais, a fim de derrubar o governo recém-empossado. No fim, foi derrotado em setembro do mesmo ano na Batalha de Santa Rosa pelas forças lideradas pelo então general, e futuro presidente, Julio A. Roca.

Passou cerca de um ano preso pela tentativa de sublevação, porém, recebeu a anistia política e, mais tarde, em 1878, voltou a ser eleito, dessa vez para o cargo de senador nacional ${ }^{79}$. Voltaria a se envolver em levantes revolucionários na década de 1880 , contra o governo Roca, com o qual se reconciliou em termos amigáveis, e em 1890, conforme já descrito, na Revolução do Parque, contra o governo Celman. No entanto, não voltou a ser presidente da república e nem a ocupar cargos públicos de grande relevância, o que não afetou, no entanto, a sua imensa popularidade política e o seu papel de influência junto à nova geração de políticos pós-1880, sobretudo no que tange à formação de alianças e apaziguamento de conflitos existentes.

Nos últimos anos de sua vida, quando observou o surgimento da União Cívica Radical na década de 1890 e o apelo revolucionário do modus operandi dos líderes radicais, compreendeu que se fazia necessário passar por cima de velhas rixas políticas por meio de uma sólida aliança entre as lideranças políticas tradicionais, de modo a conter o avanço radical e as constantes tentativas de sublevação revolucionárias intentadas por

\footnotetext{
${ }^{77}$ ULANOWSKI, Idem.

${ }^{78}$ Idem.

${ }^{79}$ DE MARCO, Idem, pág. 363.
} 
seus líderes. Deste modo, Mitre foi um dos operadores principais da chamada "política de notáveis" que configurou os últimos anos do regime autonomista. Mitre faleceu a 19 de janeiro de 1906 com 84 anos de idade, e seus restos mortais descansam no Cemitério de la Recoleta.

Mitre não viveu o suficiente para ver o fim do autonomismo e a chegada ao poder dos radicais, no entanto, ao longo de sua vida, viu e participou ativamente de inúmeras e suficientes modificações no seio político argentino. Sua atitude beligerante, muitas vezes explosiva, tampouco os espasmos de cortesia diplomática que o rodeavam, denotaram a intensidade opositora do La Nación durante a sua vida, bem como na posteridade. Ainda na atualidade, conforme afirmado em 1996 pelo então secretário geral de redação do jornal, José Escribano, a tradição mitrista compõem parte essencial da ideologia do jornal

"La presencia de Mitre perdura en lo que concierne al uso de la libertad, la defensa de las garantías individuales, la independencia de los poderes públicos y el ejercicio de un criterio pluralista en todos los órdenes (...) El espíritu de Mitre persiste, en especial en los editoriales, en donde siempre trató de mantener principios del liberalismo bien" $" 80$ (Grifo Meu)

A oposição inerente aos governos radicais, sobretudo ao primeiro governo de Hipólito Yrigoyen, denotou-se por essas mesmas características. Forte personalismo político, execução de intervenções federais tomadas de forma unilateral e sem o conhecimento do parlamento, uso da coisa pública para interesses partidários, fatiamento de cargos públicos em face de alianças políticas: essas acusações compuseram o escopo da retórica opositora do jornal La Nación ao primeiro mandato de Yrigoyen, delineando o futuro do jornal frente ao retorno deste último à Casa Rosada em $1928^{81}$.

\subsection{Os outros veículos de imprensa opositores: o movimento nacionalista}

$\mathrm{Na}$ aurora do período democrático representativo argentino, na década de 1910, surgiu o movimento nacionalista argentino, expressão da influência de renomados intelectuais, tais como Ricardo Rojas, Manuel Gálvez, Leopoldo Lugones e os irmãos Rodolfo e Julio Irazusta, dentre tantos outros, no escopo de publicações editoriais contrárias aos governos da União Cívica Radical ${ }^{82}$. Ao longo de 14 anos de era radical,

\footnotetext{
${ }^{80}$ Apud ULANOWSKI, Idem.

${ }^{81}$ ULANOWSKI, Carlos. Paren las rotativas I: 1920 - 1969. Buenos Aires: Emecé, 2005, pág. 58.

${ }^{82} \mathrm{O}$ movimento nacionalista foi analisado anteriormente em monografia de conclusão de curso:
} 
esses intelectuais representaram um novo setor político que não se compunha com nenhum dos outros grupos políticos já existentes. Poucas foram as ocasiões em que esse setor, amplamente reconhecido na historiografia argentinista como "nacionalista" 83 , se congregou com os liberais-conservadores que até então dominavam os partidos à direita do quadro político argentino, e em nenhuma ocasião se aliaram à esquerda existente, tanto a moderada, quanto a radical.

O movimento nacionalista argentino buscava desenvolver, a partir de bases culturais hispano-argentinas, um nacionalismo próprio para a nação. No entanto, baseavase na tradição cultural hispânica e nos modelos corporativistas em voga na Europa pósPrimeira grande guerra, sobretudo em relação ao regime fascista liderado por Benito Mussolini na Itália, para criar o seu ideário político e cultural. Defendia uma "Argentina para os argentinos", ou, como afirmava o romancista Ricardo Rojas, lutava em defesa da “argentinidad" $"$. Por conseguinte, desafiava tanto a velha ordem liberal que governara o país desde a unificação, a qual era acusada de toda espécie de denúncias quanto ao "enfraquecimento" da legítima cultura argentina, quanto atacava a nova democracia de massas, que permitiu o alçamento ao poder dos radicais e, sobretudo, de seu líder Hipólito Yrigoyen.

Esse movimento fez amplo uso dos meios de comunicação para expandir a sua ideologia entre a população. Porém, foi por meio da imprensa escrita que melhor expressou a heterogeneidade do pensamento de seus expoentes. Como foi dito, o

RORIZ, Diogo D'Angelo de Araujo. La Hora de la Espada: as origens do movimento nacionalista argentino (1920-1930). 2013. 42 f. Monografia (Bacharelado e Licenciatura em História) — Universidade de Brasília, Brasília, 2013.

83 A historiografia sobre o tema costuma utilizar diversos conceitos diferente para caracterizar o nacionalismo argentino surgido nos anos 1920, dentre eles "contrarrevolución" e "extrema derecha", termos utilizados por Sandra Mcgee Deutsch sem grande aprofundamento conceitual, e "movimiento nacinalista", usado por David Rock a partir de uma análise melhor aprofundada acerca da heterogeneidade e especificidade deste nacionalismo, e com o qual esta dissertação concorda.

MCGEE DEUTSCH, Sandra. Contrarrevolución en la Argentina: La Liga Patriótica Argentina (19001932). Buenos Aires, 2003

Aires, 2005.

Sandra. Las derechas: La extrema derecha en la Argentina, el Brasil y Chile, Buenos

ROCK, David. La Argentina Autoritaria: Los Nacionalistas, su historia y su influencia en la vida pública. 2. ed. Buenos Aires: Editora Ariel, 1993.

${ }^{84}$ FLORIA, Carlos. Pasiones nacionalistas. Buenos Aires: Fondo de Cultura Económica, 1998, p. 71. Segue uma passagem, extraída de um livro por ele publicado nos primeiros anos do século XX, que torna salutar o seu pensamento acerca da influência "permissiva" do imigrante: "Bástenos recordar que una cantidad exorbitante de brazos italianos trabaja nuestros campos, y que una cantidad extraordinaria de capitales británicos mueve nuestras empresas. En medio de este cosmopolitismo de hombres y capitales, que nos somete a una verdadera sujeción económica, el elemento nativo abdica en la indiferencia o el descatamiento de las ideas" ROJAS, Ricardo. La restauración nacionalista IN DONGHI, Tulio Halperin. Vida y muerte de la República verdadera (1910-1930). Biblioteca del Pensamiento Argentino IV. Buenos Aires: Emecé, 2007, p. 24. 
pensamento nacionalista argentino, apesar de também estar presente na visão liberal e radical, apresenta-se de modo muito heterogêneo e com grande pluralidade de ideias e acepções. Identifica-se, como característica geral dos escritos nacionalistas, uma recusa às influências sociais, políticas e culturais vindas do estrangeiro. Opusera-se à influência anglo-francófona sobre a política argentina, sobretudo a partir da produção historiográfica de seus próceres, que alimentaria o revisionismo nacionalista das décadas de 1930 e $1940^{85}$. Esse nacionalismo também se colocou contra a política imigratória adotada a partir de 1890 pelos governos autonomistas, que serviu de base para formulação do eleitorado radical.

No entanto, sua crítica ao "estrangeirismo" das políticas adotadas pelos grupos políticos tradicionais se baseava em ideias vindas, em sua maioria, do próprio continente europeu, como apontaram, entre outros, os trabalhos de Federico Finchelstein ${ }^{86}$, Fernando Devoto e Maria Inés Barbero ${ }^{87}$, Diana Quattrocchi-Woisson ${ }^{88}$ e Tulio Halperín Donghi ${ }^{89}$, David Rock ${ }^{90}$, e outros. Esses mesmos autores, apesar de apresentarem diferentes matizes no tratamento da questão nacionalista argentina, concordam que a heterogeneidade de pensamento verificado entre seus expoentes principais dificulta identifica-los como um grupo coeso ou mesmo uma espécie de "escola de pensamento nacionalista". No entanto, também concordam em um aspecto essencial da índole nacionalista, qual seja, a de que esses pensadores surgidos no bojo da Grande guerra buscavam refletir o povo argentino como um organismo social harmônico, dividido em diferentes classes sociais com funções e privilégios distintos, e fundados sobre a tradição cultural hispânica-católica.

Os estudiosos do tema também afirmam que a retórica nacionalista, apesar de essencialmente antiliberal e contrária ao regime anterior à lei Sáenz Peña, se coadunou, por puro pragmatismo estratégico, com os liberais de outrora no tocante à pauta de oposição aos regimes radicais. Por meio de inúmeros jornais e revistas publicados nos anos 1920, dos quais se destacavam a revista Criterio e os jornais La Nueva Republica

\footnotetext{
${ }^{85}$ HALPERIN DONGHI, Tulio. El revisionismo histórico argentino como visión decadentista de la historia nacional. $1^{\mathrm{a}}$ ed. Buenos Aires: Siglo XXI Editores Argentina, 2005.

${ }^{86}$ FINCHELSTEIN, Federico. La Argentina fascista: los orígenes ideológicos de la dictadura. Nudos de la Historia Argentina. Buenos Aires: Sudamerica, 2008

FINCHELSTEIN, Federico. Fascismo, liturgia e imaginário. El mito del general Uruburu y la Argentina nacionalista. Buenos Aires: Fondo de Cultura Económica, 2002.

${ }^{87}$ BARBERO, María Inés; DEVOTO, Fernando. Los Nacionalistas (1910-1932). Biblioteca Politica Argentina. Buenos Aires: Centro Editor de América Latina, 1983.

${ }^{88}$ QUATTROCCHI-WOISSON, Diana. Los Males de la Memoria: Historia y Politica en la Argentina. Buenos Aires: Emecé, 1995.

${ }^{89}$ HALPERIN DONGHI, Tulio. Idem.

${ }^{90}$ ROCK, Idem.
} 
dos irmãos Irazusta e o La Fronda, os autores nacionalistas fizeram um longo e ininterrupto expediente de oposição aos regimes da UCR, em especial ao primeiro governo de Yrigoyen. Eis uma das principais linhas presentes no pensamento nacionalista: o antiyrigoyenismo e o antiradicalismo.

Não obstante a existência de meios de imprensa próprios, os nacionalistas também escreveram nos jornais La Nación e La Prensa, quer nas suas páginas de opinião, quer nos respectivos cadernos de cultura. É o caso de Leopoldo Lugones, Ricardo Rojas e Manuel Gálvez, que em inúmeras vezes publicaram artigos em ambos jornais, algumas vezes tecendo leves e quase insondáveis críticas a esses próprios diários. O jornal La Nación, principalmente, conforme percebido na análise de suas edições diárias entre 1928 e 1930, abria espaço para diversas publicações destes e de outros autores identificados com a ideologia nacionalista, e quase sempre apresentando virulentas críticas, nesse momento, ao retorno de Yrigoyen ao poder, o que não significa um atrelamento do jornal ao nacionalismo, porém, um atrelamento de objetivos em comuns com esses grupos.

Estes jornais identificavam na figura de Hipólito Yrigoyen a ascensão de uma espécie de caudilhismo social profundamente avesso à harmonia de classes até então vigente na sociedade argentina. Yrigoyen encarnava a imagem do típico líder forte e carismático capaz de engendrar as massas em torno de um argumento em comum, e neste caso, um argumento visivelmente contrário às elites políticas tradicionais, o que é claramente observado em seus anos de ativismo anti-autonomismo.

Dentre os intelectuais nacionalistas que melhor encarnaram o espírito antiyrigoyenista durante a década de 1920, encontra-se a figura do escritor Leopoldo Lugones. Um convicto ex-socialista convertido ao pensamento anticomunista e antiliberal no pós-Grande Guerra, Lugones foi um intelectual de muitas e heterogêneas facetas ao longo de sua vida. Durante a década de 20, publicou romances, contos e poemas dedicados à insuflação de um espírito argentinista em sua nação. Nestes mesmos anos, Lugones conquistou diversos grupos sociais, sobretudo ligados ao nacionalismo em voga, por meio de discursos inflamados de ojeriza à democracia de massas e virulentos ataques aos governos de Yrigoyen.

Ainda em 1916, quando da primeira eleição de Hipólito Yrigoyen, Leopoldo Lugones foi direto em sua crítica ao sistema eleitoral que teria permitido a ascensão política do histórico radical: "Solemnes, tremebundos, inmunes con la representación parlamentaria, así se vinieron. La ralea mayoritaria paladeó [...] a quien nunca habían 
tentado las lujurias del sufragio universal. "91. A crítica ao sistema de voto majoritário e universal se tornou uma constante entre os opositores nacionalistas, mas em especial nos escritos de Leopoldo Lugones.

Os eixos de ataque ao regime radical perpassavam a crítica à democracia, ao menos segundo a visão adotada a partir de 1912, à corrupção radical, vista como algo inerente a um sistema clientelista e caudilhesco como o adotado durante os anos Yrigoyen, e ao autoritarismo percebido por entre determinadas medidas centralistas adotadas pelo governo, sobretudo a partir do uso constante das intervenções federais nas províncias governadas pela oposição política. A maior parte dos nacionalistas decidiram se dedicar, em sua oposição ao governo, à formulação de ideias no campo da filosofia política, por meio da contestação dos ideais de República e democracia adotados ao longo das décadas anteriores na Argentina, cuja última cartada fora a própria ascensão da UCR.

Julio e Rodolfo Irazusta, fundadores do jornal La Nueva Republica, advogaram firmemente contra o regime democrático pós-1912. Eles acreditavam que a inserção de massas de cidadãos pertencentes às classes mais baixas e mais voláteis às ações carismáticas de um líder político como Yrigoyen, acabaria por corromper as bases republicanas, destituindo as lideranças políticas representativas de seu lugar de fala em face de uma liderança volúvel e autoritária, cujo poder haveria de emanar exclusivamente da vontade das massas, em detrimento das instituições republicanas. Julio Irazusta, ademais, conclui que a própria ideia de democracia "es la utopía, la abstracción" "92, pois:

en su opinión, la democracia es factible sólo en una sociedad compuesta de un puñado de ciudadanos y gran cantidad de esclavos como las sociedades greco-romanas, y esa adopción en la sociedad moderna produciría 'la nivelación por abajo' 93

Apesar de apresentarem a mesma sensibilidade em relação ao "problema radical" e suas causas aparentes, os irmãos Irazusta se afastavam de Lugones quanto às propostas de solução ao impasse gerado pela fórmula democrática argentina. Para os primeiros, a solução seria a reformulação do sistema eleitoral, de modo a privilegiar as capacidades pessoais em detrimento da mera universalização irrestrita do voto masculino. Aplica-se

\footnotetext{
${ }^{91}$ LUGONES, Leopoldo. Payador y antologia de poesia y prosa. Caracas: Biblioteca Ayacucho, 1979, p. 48.

${ }^{92}$ IRAZUSTA, Julio. Republica y democracia. La Nueva Republica, 15-3-1928 IN BARBERO; DEVOTO, Idem, p. 101.

${ }^{93}$ MUTSUKI, Noriko. Julio Irazusta: Treinta años de nacionalismo argentino. Buenos Aires: Biblos, 2004, p. 59.
} 
aí a ideia de que a representação política, por sua aspiração máxima ao bem comum, deve antes ser um privilégio de poucos, aqueles bem preparados para exercer tamanha responsabilidade pública, do que um direito abstrato de muitos, os quais, muitas vezes, ignorariam a responsabilidade social ocasionada pelo seu voto em nome do sentimento e da vontade pessoal.

No entanto, para Lugones, a solução para o problema avaliado passaria, inevitavelmente, pela via armada. Sua aproximação dos ideais fascistas italianos ao longo dos anos 1920 fomentou a aspiração por uma sociedade militarizada que pusesse fim aos males nacionais de modo definitivo, a começar pela democracia. Para ele, o sistema democrático era essencialmente fraco e covarde, por sua crença excessiva nas instituições políticas representativas da vontade popular. Seu ideal de sociedade, por outro lado, representaria o que há de mais forte, viril e organizado na sociedade moderna: a formação militar. Uma sociedade militarizada seria a única forma possível de garantir a verdadeira paz, ou seja, a paz armada, abalada pela "utopia" liberal no pré-Grande Guerra.

Em 1924, Lugones proferiu as célebres conferências ${ }^{94}$ na cidade de Ayacucho, Perú, em comemoração pelo centenário da Batalha de Ayacucho, considerada a última grande batalha das guerras de independência na América do Sul. A importância dessas conferências repousa no teor dos discursos ali proferidos pelo escritor, baseados em uma retórica antidemocrática e pró-militarista. Por meio delas, Lugones resumiu a sua visão de sociedade ideal:

Ha sonado otra vez, para bien del mundo, la hora de la espada [...] El pacifismo no es más que el culto del miedo, o una añagaza de la conquista roja, que a sua vez lo define como un prejuicio burgués. La gloria y la dignidad son hijas gemelas del riesgo; y en el proprio descanso del verdadero varón yergue su oreja el león dormido. La vida completa se define por cuatro verbos de acción: amar, combatir, mandar, enseñar [...] La vida misma es un estado de fuerza..$^{95}$

Sua solução seria, portanto, a destituição das massas eleitorais do meio político, bem como de seus representantes, a homogeneização das mesmas em torno de um único e grandioso ideal nacional e a elevação das Forças armadas à liderança política. Assim ele próprio resumia: "Nuestro sistema constitucional no tiene ya remedio dentro de sí mismo,

\footnotetext{
${ }^{94}$ LUGONES, Leopoldo. Acción: Las cuatro conferencias patrióticas del Coliseo: 6, 11, 14 y 17 de julio de 1923. Buenos Aires: Est. Gráfico A. de Martino, 1923, p. 8 IN Disponível em: http://www.bnm.me.gov.ar/cgi-

bin/wxis.exe/opac/?IsisScript=opac/bibdig.xis\&dbn=LUGONES\&src=link\&tb=tem\&query=CONFERE NCIAS\&cantidad $=\&$ formato=breve\&sala. Acesso em: 20/11/2012.

${ }^{95}$ LUGONES, Idem, p. 306.
} 
porque está muerto [...]Creo en la democracia latina, que siendo una selección, no excluye al pueblo ni a la dictadura o Ejecutivo fuerte ${ }^{96}$. Apesar de abraçar a crítica nacionalista em relação ao suposto autoritarismo encabeçado por Hipólito Yrigoyen à frente do governo, Lugones acabava por defender uma sociedade cujo Poder executivo, liderado pelas Forças Armadas, submeteria os demais poderes republicanos ao seu jugo.

Percebe-se, portanto, uma constante na forma de encarar o presente político pós1916 dentre os expoentes do movimento nacionalista argentino, qual seja, a defesa do expurgo da União Cívica Radical do poder, quiçá do próprio cenário político nacional, e a implementação de mudanças radicais nos rumos a serem seguidos pela nação. Os embates políticos protagonizados pela oposição nacionalista aos governos radicais tornou-se algo constante na vida política argentina durante os anos 1920, e foi um dos principais fatores que levaram ao levante militar de 1930.

\subsection{Do primeiro governo de Hipólito Yrigoyen (1916-1922)}

O período 1912 a 1916 foi marcado pela concretização dos rumos ditados pela Lei Sáenz Peña na política nacional argentina. Em consequência aos ditames da lei, o sufrágio universal masculino, agora secreto, passaria a contar com o apoio dos organismos estatais competentes no combate às fraudes eleitorais que tão bem caracterizaram o momento político anterior à promulgação da lei. Porém, a busca pela transparência nas corridas eleitorais não foi a única consequência resultante desta lei. $\mathrm{Na}$ mesma medida, a pacificação do meio político pôde ser observada nos anos seguintes a sua vigência, à revelia de eventuais embates ainda existentes em determinadas províncias do interior.

Como deixa claro o trabalho até aqui desenvolvido, o resultado imediato angariado da nova realidade eleitoral foi a chegada ao poder da União Cívica Radical, primeiramente com a vitória em algumas províncias, e em seguida, no ano de 1916, com a vitória de Hipólito Yrigoyen no pleito eleitoral à presidência da república. Pela primeira vez um representante radical assumiria o mais alto posto da política nacional. Seu primeiro mandato presidencial, desenrolado até o ano de 1922, lidou com questões bastante delicadas quanto à condução de uma nação em amplo estágio de crescimento

\footnotetext{
${ }^{96}$ AYARRAGARAY, Lucas. IN HALPERIN DONGHI, Vida y muerte de la República verdadeira, Idem, pág. 415.
} 
econômico e internacional, que, à revelia de seu portentoso desenvolvimento, encontravase ainda dividida entre diferentes visões de futuro por parte de suas elites políticas. ${ }^{97}$

Juan Hipólito del Sagrado Corazón de Jesús Yrigoyen, mais conhecido somente por Hipólito Yrigoyen, ou ainda Dr. Yrigoyen, nasceu no dia 13 de julho de 1852, filho de Martín Yrigoyen, um francês de origem basca, e Marcelina Alem, irmã de Leandro Alem, o futuro fundador da União Cívica Radical, e mestre político de Yrigoyen. Cresceu em uma pequena e simples propriedade de terra nos arredores de Buenos Aires, ajudando o seu pai em sua criação de cavalos. Estudou em colégios internos católicos, e graças ao estudo ali recebido, conseguiu estudar direito, graduando-se aos 25 anos de idade ${ }^{98}$.

Apesar de ter recebido a educação formal no colégio e faculdade, Yrigoyen recebeu sua educação prática a partir da forte influência recebida de seu tio Leandro Alem. Com ele, aprendeu o dom da oratória, pelo qual um bom político seria capaz de angariar o apoio, e até mesmo o amor e devoção, das massas populares. Em 1877, Yrigoyen assumiu como deputado da Província de Buenos Aires.

Mais tarde, na década de 1880, foi eleito deputado nacional pelo partido autonomista, porém, terminado o seu mandato, Yrigoyen decidiu não mais se candidatar por nenhum dos partidos pertencentes ao establishment, e passou a militar nas ruas ladoa-lado com Alem. Seu longo aprendizado foi posto em prática durante os eventos da Revolução do Parque de 1890, em que participou ativamente ao lado de Alem. Um ano depois, em 2 de julho de 1891, ele participou da fundação da União Cívica Radical, partido do qual assumiria a liderança poucos anos depois ${ }^{99}$.

Como líder da União Cívica Radical, UCR, posto assumido definitivamente após o falecimento de Leandro Alem e uma vez derrotado Bernardo de Irigoyen, Hipólito Yrigoyen forçou o partido a seguir uma linha cada vez mais dura e voltada à intransigência, isto é, à recusa de acordos com outros partidos que pudessem fazer com que a UCR desviasse de suas doutrinas básicas.

Seguindo essa linha intransigente, Yrigoyen buscou, cada vez mais, valer a sua vontade pessoal sobre o conjunto do partido, e buscou também chegar ao poder por meio

\footnotetext{
${ }^{97}$ TATO, Maria Inés. Crónica de un desencanto: una mirada conservadora de la democratización de la política, 1911-1930. Estudios sociales 20. Revista Universitaria Semestral, No 20, 2001, pp. 147.

98 ÁLVAREZ GUERREIRO, Osvaldo. Hipólito Yrigoyen ante la condición humana. Revista Polis: Revista Latinoamericana. Disponível em: http://polis.revues.org/5437. Acesso em: 15 agosto 2015, pág. 2. ${ }^{99}$ QUIJADA, Mónica. Hipolito Yrigoyen. Buenos Aires: Ediciones Quorum, 1987, pág. 34; LUNA, Félix. Yrigoyen. Buenos Aires: Desarrollo, p. 196, capítulo 8; GALVEZ, Manuel. Vida de hipolito yrigoyen, el hombre del misterio. Buenos Aires: G Kraft, 1939, p. 207.
} 
da via revolucionária ${ }^{100}$. Das várias tentativas de revolução radical, destaca-se a de 1905 , em que Yrigoyen buscou derrubar o governo à força, no entanto, a tentativa se mostrou fracassada, e os envolvidos nela foram enviados para uma duríssima prisão de segurança máxima na Patagônia, onde permaneceram por dois anos, até o governo argentino decretar a anistia dos mesmos. Yrigoyen não chegou a ir para essa prisão, porém se rendeu frente a um juiz federal, que o concedeu a liberdade mediante pagamento de fiança ${ }^{101}$. Da tentativa fracassada de revolução, a imagem de Yrigoyen saiu ainda mais fortalecida frente ao povo. A revolução de 1905 foi crucial para trilhar o caminho rumo à lei Sáenz Peña de 1912, que permitiria a chegada da UCR ao poder.

A eleição de Hipólito Yrigoyen, então com 64 anos de idade, para a presidência da República trouxe como marca a ascensão das camadas médias urbanas ao cenário político nacional. O grosso dos grupos apoiadores da União Cívica Radical concentravase em torno do operariado de Buenos Aires e das demais províncias, com presença marcante em Santa Fé, Mendoza, San Juan, Corrientes e Patagônia, onde se despontava um caudilhismo de fortes bases populares, tal qual aquele afiançado pelo próprio Yrigoyen $^{102}$.

O novo governo teve como meta formular grandes mudanças na estrutura estatal. Entre as suas principais bandeiras se encontravam a criação de novas leis trabalhistas, uma maior participação estatal na condução econômica e reformas sociais amplas, como a da educação. Outrossim, a principal meta de Yrigoyen foi o fortalecimento da UCR como partido hegemônico a nível nacional, com a liderança centralizada de modo cada vez mais contundente em torno de si próprio. Como se verá mais à frente, as tentativas de personificação do partido à imagem de seu líder máximo, o que se chamou de "personalismo"103, apesar de razoavelmente bem-sucedido em meio a parcelas significativas do eleitorado radical, não logrou máximo êxito nos anos seguintes, sobretudo por conta da crescente oposição interna sofrida por Yrigoyen por dissidentes políticos e/ou por parte de outras figuras que buscavam, elas próprias, alcançarem o posto da liderança radical.

\footnotetext{
${ }^{100}$ ROCK, David. El Radicalismo argentino. Buenos Aires: Amorrortu, 1977, pág. 62.

${ }^{101}$ QUIJADA, Idem, pág. 58.

${ }^{102}$ HOROWITZ, Joel. Argentina's Radical Party and Popular Mobilization, 1916-1930. Pennsylvania: Penn State Press, 2008, cap. 5; BERTONI, Lilia Ana; DE PRIVITELLIO, Luciano (Org.). Conflictos en la democracia: la vida política argentina entre dois siglos 1852-1943. Buenos Aires: Siglo Veintiuno Editores, 2009.

${ }^{103}$ GIACOBONE, Carlos; GALLO, Edit Rosalía. Radicalismo bonaerense 1891-1931: la ingeniería política de Hipólito Yrigoyen, Buenos Aires: Corregidor, 1999, pág. 24.
} 
Ao assumir o cargo, na virada para o ano de 1917, Yrigoyen precisou lidar com uma questão deveras pujante no seio internacional: a Primeira Guerra Mundial, já bastante avançada e, apesar de não se saber à época, perto de seu fim, e o papel argentino entre as lideranças mundiais ${ }^{104}$. Em seus primeiros meses de governo, a opinião pública se viu incendiada pelo ataque de um submarino alemão a três navios mercantes argentinos, os quais rumavam, em situação de neutralidade, para a Europa. O objetivo claro da marinha alemã era impedir a entrada de suprimentos básicos nos territórios controlados pela Tríplice Entente, os quais procediam, em sua maior parte, da América do Sul, sobretudo da Argentina e Brasil ${ }^{105}$.

Apesar da comoção pública gerada pelo ataque alemão, a diplomacia yrigoyenista, seguindo, na realidade, uma conduta anterior ao próprio governo radical, recusou-se a romper relações com a Alemanha e a participar dos esforços de guerra empreendidos pelos Estados Unidos, mantendo a neutralidade até o fim da guerra ${ }^{106}$. Sua atitude buscava demarcar a esfera de autonomia daquele país frente às pressões oriundas de outras nações, especialmente de seu vizinho Estados Unidos, com o qual buscava disputar a liderança sul-americana ${ }^{107}$. Essa mesma visão, fortemente encabeçada por Yrigoyen, voltou a predominar após o término da guerra, com a recusa argentina de participar das negociações em torno da criação da Liga das Nações, por não entender um equilíbrio de poder entre as nações mais e menos poderosas na condução da mesma.

${ }^{104}$ DI TELLA, Torcuato S. História social da Argentina contemporânea. Brasília: FUNAG, 2010, pág. 155 .

${ }^{105} \mathrm{O}$ Brasil também teve, à mesma época, um de seus navios mercantes, o vapor Paraná, destruído por torpedos alemães, levando o país a romper relações diplomáticas com a Alemanha e a declarar guerra à Tríplice Aliança.

${ }^{106}$ SOLVEIRA, Beatriz. In ANGEL CÁRCANO Miguel(Org.). Nueva Historia de la Nación Argentina. Tomo VIII. Buenos Aires: Planeta, 2001, pág. 100.

${ }^{107}$ A diplomacia argentina, desde meados da década de 1890, buscou configurar uma imagem de liderança internacional para o seu país. Primeiramente com Estanislao Zeballos, ministro das Relações Exteriores durante os governos de Juárez Celman, Carlos Pellegrini e José Figueroa Alcorta, o qual definiu as bases para a diplomacia de força, que impunha a égide da liderança sul-americana à Argentina, em oposição, principalmente, aos interesses recíprocos do Brasil. Outro grande inspirador da diplomacia argentina foi Luis Maria Drago, ministro das Relações Exteriores durante o último governo de Julio Argentino Roca e criador da chamada "Doutrina Drago", de 1902, que afirmou, em resposta ao bloqueio naval à Venezuela encabeçado pela Inglaterra, Alemanha e Itália, em nome do pagamento de dívidas daquele país para com os seus credores nacionais destes, que nenhuma potência estrangeira pode fazer uso da força contra nações americanas com o intuito de cobrar dívidas, sem antes haver negociações diplomáticas. A Doutrina Drago foi na realidade uma resposta não só às atitudes encaradas como imperialistas por parte de nações europeias, mas também foi voltada a atacar a neutralidade norte-americana em relação a esse assunto, visto que, no caso venezuelano, o governo norte-americano se negou a agir quando invocado a Doutrina Monroe. Assim, tanto sob Zeballos quanto sob Drago, ainda que com matizes e interpretações diferentes e, por vezes, dissonantes, a diplomacia argentina buscou assumir a liderança de seu país sobre o continente sulamericano, de modo a isolar os EUA e o Brasil, defendendo para tanto a autonomia e independência da região em relação a outras nações estrangeiras. Para maior aprofundamento no tema, ler RAÚL SATAS, Hugo. Una Política Exterior Argentina. Buenos Aires: Hyspamerica, 1987, pág. 144. 
Os anos de 1917 e 1918 também foram marcados por disputas recorrentes entre caudilhos tradicionais e forças radicais em províncias do interior. Situações de embates políticos, permeados por fraudes eleitorais e rupturas institucionais, nas diferentes províncias do território nacional eram de tal modo recorrentes que, considerado o perigo representado por tais embates para a manutenção da ordem republicana, podia o Poder executivo federal dispor do uso das intervenções federais para a restituição da ordem pública. A intervenção federal estava prevista na Constituição Federal de 1853, em seu artigo $6^{\circ}$, e tinha por objetivo, como dito, a restauração e manutenção da ordem pública e federativa. A declaração de intervenção federal é uma prerrogativa do governo central, devendo, no entanto, o Congresso federal confirma-la. Durante o período autonomista, as intervenções foram raramente utilizadas, no entanto, somente nos dois primeiros anos de governo radical, foram declaradas 6 intervenções federais, seguidas de muitas outras nos anos seguintes ${ }^{108}$.

O mecanismo constitucional das intervenções federais logo se tornou uma potente arma nas mãos do governo de Yrigoyen. As acusações em torno do autoritarismo dessas intervenções, feitas sem justificativas plausíveis, normalmente atribuídas a alguma suposta transgressão à Lei Sáenz Peña, e sempre em províncias controladas pela oposição conservadora, abundaram na imprensa argentina e ganharam grande repercussão em meio aos parlamentares pertencentes à oposição. Os interventores enviados pelo governo central pertenciam à burocracia federal e, não poucas vezes, ao próprio corpo político do radicalismo.

Dois casos emblemáticos, e cruciais para o futuro da UCR, foram os de Mendoza e San Juan. Na primeira província, controlada pelos conservadores, a intervenção, feita ainda em 1917, levou ao poder um histórico aliado de Yrigoyen, o "gaúcho" José Néstor Lencinas. À frente do governo de Mendoza, Lencinas emplacou uma série de reformas sociais e trabalhistas, tal como a garantia do salário mínimo e da jornada de trabalho de oito horas ${ }^{109}$. No entanto, o caudilho também era conhecido pelo seu forte temperamento e pelo tratamento que dispensava aos seus opositores, sempre marcado pelo uso de força e violência.

\footnotetext{
${ }^{108}$ Províncias que sofreram intervenções nesse período: Buenos Aires (04/1917), Corrientes (11/1917), Mendoza (11/1917), Córdoba, La Rioja e Santa Fe (12/1917). Nenhuma dessas intervenções foram submetidas à apreciação do Senado, Casa designada para tal no Congresso argentino.

${ }^{109}$ DI TELLA, Idem, pág. 161.
} 
A perseguição aos opositores levou Yrigoyen a novamente decretar uma segunda intervenção à província em 1919. Nas eleições que se seguiram, Lencinas voltou a se sair vencedor no pleito eleitoral, vindo a morrer em 1920. A condução da família passou ao seu filho, Carlos Washington Lencinas, que logo sucedeu ao seu pai no governo de Mendoza. A família Lencinas e o peso de suas ações políticas angariaram grande apoio em meio à base eleitoral radical, formando-se assim a chamada "UCR Lencinista", uma facção interna ao partido que se manteve, ainda por algum tempo, leal a Yrigoyen. Algo semelhante ocorreria em 1920 na província de San Juan, onde um discípulo de Lencinas, Federico Cantoni, liderou a sua própria facção radical em meio a medidas que claramente buscavam se interpor às prerrogativas da facção nacional.

Em meio ao seu apogeu, Yrigoyen declarou a intervenção à San Juan em 1920, então governada por um conservador, e ajudou a eleger o aliado Amable Jones, opositor de Lencinas. No entanto, Jones foi assassinado em 1921. A acusação pela morte de Amable Jones recaiu sobre Cantoni, que já acumulava outras diversas acusações de perseguição a opositores, o que gerou grande tumulto armado na província, necessitandose da intervenção armada por parte do Exército nacional. Não obstante, Cantoni, e sua fama entre a base eleitoral radical local, permaneceram ilesos, e constituiu, à semelhança de Lencinas, sua própria facção interna denominada de "UCR Bloquista" ${ }^{110}$. Tanto o bloquismo, quanto o lencinismo, se tornariam, em poucos anos, dois grandes obstáculos ao yrigoyenismo, como se verá mais adiante.

Outra importante questão enfrentada por Yrigoyen em seu primeiro mandato foi a intricada, e por vezes tensa, relação existente entre o radicalismo e as organizações operárias ${ }^{111}$. Marcante foi o ano de 1919, em que diversas greves operárias se espalharam país afora, de forma coordenada a obrigar o governo a tomar medidas favoráveis aos operários. A principal greve ocorrida nesse período, depois da greve ferroviária de 1917, foi a dos operários metalúrgicos de 1919, da qual se desvencilhou diversos rumos que impactariam a Argentina na década seguinte. Esta greve levou ao enfrentamento público entre grevistas, apoiados pelas principais organizações sindicais à época, e a polícia local.

\footnotetext{
${ }^{110}$ DI TELLA, Idem.

111 "Havia nesse momento duas federações operárias. A numericamente maior, a FORA "do Nono Congresso", dirigida por sindicalistas e socialistas (...) e a FORA “do Quinto Congresso", anarquista" IN Idem, pág. 157. Enquanto a primeira estava sempre voltada ao diálogo com o governo, por conta de suas históricas relações amistosas com o radicalismo, a segunda, de linha intransigente, buscava, por sua vez, infinitas oportunidades para dar início a ocasiões revolucionárias. Ler: DE SANTILLÁN, Diego Abad. La F.O.R.A.: Ideologia y Trayectoria del movimiento obrero revolucionario em la Argentina. Buenos Aires: Ediciones HL, 2006.
} 
Em sua origem, o enfrentamento levou à morte de 4 pessoas, o que viria a aumentar nos dias seguintes, por conta do próprio aumento das tensões entre grevistas e governo. A impassibilidade do governo central em buscar soluções plausíveis ainda na origem das manifestações colaborou com a intensificação dos conflitos e com a entrada em cena de grupos paramilitares civis, ligados ao nascente movimento nacionalista, que viriam dar origem à Liga Patriótica Argentina, sob o comando de Manuel Carlés, um importante personagem político que oscilou deveras vezes entre o radicalismo e o nacionalismo $^{112}$

Entre 9 e 14 de janeiro de 1919 transcorreu uma enorme greve geral, convocada pelos FORA, que se espalhou, a partir da capital portenha, pelas províncias de Buenos Aires, Córdoba, Santa Fe e Mendoza. Os dias que se seguiram ao estopim da greve geral foram marcados por um abrupto choque de armas envolvendo grevistas, tanto os sindicalizados quanto os anarquistas, forças militares oriundas do Exército e da Marinha, e grupo de civis armados que foram organizados por militares da Marinha em conjunto com intelectuais e políticos nacionalistas e radicais ${ }^{113}$. Esses dias de conflitos ficaram conhecidos como a Semana Trágica de 1919.

Os conflitos armados da Semana Trágica foram motivados pelo medo gerado entre militares e civis de que entre os grevistas houvessem "bolcheviques" infiltrados:

"Las noticias de la revuelta espartaquista en Alemania, de huelgas y,
manifestaciones en Chile y una supuesta conspiración "maximalista"
(comunista) en Montevideo alimentaron sus temores. Los problemas
económicos y la amenaza obrera también avivaron los sentimientos
antisemitas. Muchos porteños sospechaban que los judios, debido a su
origen principalmente ruso, eran de tendência bolchevique o
anarquista."

Seguiu-se um clima de radicalização e confrontos que não se via desde as greves do Centenário em 1910. Ocorreram saques, assaltos e tiroteios, com mortes sendo registrados a todo momento, bem como ataques paramilitares, compostos principalmente de radicais, à grevistas e bairros judeus de Buenos Aires. Era esperada uma ação decidida por parte de Yrigoyen, para pôr fim à essa situação, mas o presidente não o fez enquanto transcorreu a Semana Trágica ${ }^{115}$. Na ausência da liderança nacional, ganhou força entre

${ }^{112}$ MCGEE DEUTSCH, Sandra. Contrarrevolución en la Argentina: La Liga Patriótica Argentina (19001932). Buenos Aires: Universidad Nacional de Quilmes Editorial, 2003, pág. 93.

${ }^{113}$ Idem, p. 82-83.

${ }^{114}$ Idem.

${ }^{115}$ Idem, pág. 85. 
as multidões o nome dos generais responsáveis pelo controle da situação, ainda que alguns destes tenham colaborado com o acirramento dos ânimos, ao distribuírem armas às patrulhas civis, sobretudo nos encontros organizados no Centro Naval.

Terminada a Semana Trágica, muitos grupos de operários e judeus admoestaram o presidente Yrigoyen a criar investigações acerca dos abusos cometidos durante os dias de revolta e a adotar medidas preventivas quanto à segurança daqueles envolvidos na greve geral, sobretudo em torno dos bairros e comércios judeus, uma vez que os grupos paramilitares ainda se encontravam em alerta. Esses mesmos grupos foram reunidos pelo contra-almirante Manuel Domecq no dia 15 de janeiro no Clube Naval, e dessa reunião surgiu a Liga Patriótica Argentina, uma conjunção de militares descontentes com o governo, de radicais descontentes com os grevistas opositores do governo e de civis e intelectuais identificados com o nacionalismo e descontentes com toda a estrutura política e social argentina ${ }^{116}$.

A criação da Liga Patriótica teve poucas repercussões imediatas sobre o governo de Yrigoyen, no entanto, foi em torno dela que se reuniram o grosso dos intelectuais nacionalistas que despontariam a partir de 1922 na cena cultural argentina, bem como suas inúmeras organizações, grupos de estudo, jornais, revistas culturais, etc. Foi também graças à Semana Trágica e à inércia do governo radical no combate ao caos civil, interpretado por esse nascente movimento nacionalista como uma adesão do yrigoyenismo aos ideias revolucionários de esquerda, que elevou de vez o presidente Hipólito Yrigoyen ao trono de maior inimigo do nacionalismo argentino.

Ocorre que não somente os nacionalistas se mostravam insatisfeitos com as políticas laureadas pelo yrigoyenismo e pela sua proximidade com as camadas médias e baixas da população, responsáveis únicos, na visão daqueles, das cenas lamentáveis vistas em janeiro de 1919 e em outros momentos. Também parcelas significativas dos militares se mostravam inquietos em relação aos rumos adotados pelo governo radical. De certo que muitos generais tinham grande proximidade com o radicalismo, uma outra parte deles, historicamente identificados com o antigo regime político pré-1912, estavam consternados com os usos e desusos praticados por parte do governo em relação às Forças armadas. $^{117}$

Muitos oficiais do Exército se mostraram preocupados, e até mesmo irritados, com os usos autoritários que o governo fazia de suas forças, utilizando-as, principalmente, para

\footnotetext{
${ }^{116}$ Idem, pág. 88.

${ }^{117}$ OYARZÁBAL, Guillermo A. In Nueva Historia de la Nación Argentina, Idem, pág. 181.
} 
afogar rebeliões opositoras nas províncias e levantes contrários ao governo central. Além disso, Yrigoyen costumava passar por cima de regras internas ao exército para nomear os seus aliados para altos cargos do oficialato. Como fala o historiador Luis Alberto Romero:

O Exército, que tinha sido organizado desde o início do século sobre bases estritamente profissionais, começou a se interessar pelo desenrolar dos assuntos políticos, talvez incomodado pela forma com que Yrigoyen o empregava para abrir e fechar a válvula do controle social, e talvez também preocupado pelo uso que o presidente fazia de critérios políticos na condução da instituição. O certo é que a desconfiança de Yrigoyen foi criando as condições para deixa-lo mais propenso às críticas mais gerais ao sistema democrático $(. . .)^{118}$

O critério político para a nomeação de cargos, aliás, não ocorreu somente nos quadros da caserna, como também abundou ao longo do governo de Yrigoyen em meio à burocracia estatal. A nomeação de aliados para cargos comuns e estratégicos do Estado foi uma prática recorrente nas gestões radicais, no entanto, foi Yrigoyen quem mais fez uso dessa política de nomeações. O objetivo principal era distribuir cargos públicos em troca de apoio político, sobretudo em barganha com deputados nacionais e provincianos em busca de apoio da aprovação de projetos de lei chaves para o governo. Yrigoyen buscou se aproveitar da maioria que possuía na Câmara, ainda que a relação entre Executivo e Legislativo nacional fosse deveras conturbada. No entanto, seu maior foco de ação foi, de fato, o controle das províncias, de modo a garantir o controle eleitoral, o que veio a acontecer em 1922.

Todo o primeiro mandato de Yrigoyen, já inflamado por grandes greves operárias, conflitos provinciais, disputas de poder internas ao radicalismo, descontentamento por parte dos militares e ascensão de uma nova oposição nacionalista, precisou lidar ainda com a crise econômica advinda do término da Primeira Guerra Mundial. Durante a guerra, o governo argentino conseguiu, em meio às dificuldades geradas pelo conflito, tais como a queda no preço das exportações e o aumento do custo do transporte dos produtos argentinos para a Europa, manter de algum modo o escoamento dos principais itens de exportação, sobretudo a carne e os cereais ${ }^{119}$. De todo modo, ainda que tenha conseguido manter o escoamento de boa parte destes produtos, devido à queda nos valores e o aumento dos custos, a rentabilidade com as exportações sofreu uma grande baixa entre 1913 e $1917^{120}$.

\footnotetext{
${ }^{118}$ ROMERO, Luis Alberto. História Contemporânea da Argentina. Rio de Janeiro: Jorge Zahar Ed., 2006, pág, 42.

${ }^{119}$ ORTIZ, Javier. In Nueva Historia de la Nación Argentina, Idem, pág. 530.

${ }^{120}$ Idem, pág. 48.
} 
Ao assumir a presidência em 1916, Yrigoyen precisou lidar com uma crise econômica ainda em ascensão na Argentina. O principal problema enfrentado nesse quesito foi a forte presença dos EUA na economia argentina a partir do estopim da guerra. Tradicionalmente, o Império Britânico fora, desde a unificação argentina, o seu principal parceiro econômico. A parceria se mostrou, ao longo das décadas, bastante frutífera para ambas nações, e funcionava basicamente da seguinte forma: os ingleses compravam carne e cereais da Argentina, e os pagava com os lucros gerados a partir da venda de "equipamento ferroviário, carvão, têxteis e com os lucros obtidos das ferrovias e de outras empresas de serviço" ${ }^{121}$. Essa economia de trocas garantiu a prosperidade econômica e social argentina entre 1880 e 1914. Porém, com a guerra surgiram grandes problemas.

Devido aos esforços de guerra ingleses, que demandavam grande parte de sua economia, os investimentos desse país no solo argentino arrefeceram durante os anos de guerra, abrindo margem para a entrada dos banqueiros norte-americanos. Contudo, a carne e os cereais argentinos não interessavam aos norte-americanos, pois eram produtos nos quais os EUA competiam em exportações com a própria Argentina. O que lhes interessava era a exportação de produtos industrializados e o empréstimo de dinheiro a este país. Percebe-se que, pela falta de interesse norte-americano na compra de produtos argentinos, logo a situação se tornou desfavorável para a economia argentina, com uma balança de pagamentos desequilibrada e queda nas exportações de carne. ${ }^{122}$

Esst foi a situação exposta ao governo de Yrigoyen: por um lado, havia a tradicional parceira econômica, a Grã-Bretanha, impossibilitada de manter os níveis de comércio anteriores à guerra, porém ainda interessada em manter a sua posição hegemônica, e por outro lado havia o cobiçado capital norte-americano, capaz de manter por algum tempo a economia em queda, porém, tal como uma faca de dois gumes, esse mesmo capital seria capaz de solapar as bases da economia argentina no longo prazo. Soma-se a isso um agravante: devido à presença cada vez mais maior de empresas e bancos norte-americanos na Argentina, os britânicos ameaçavam o governo argentino de transferir as suas compras para outros países da Commonwealt ${ }^{123}$, caso não houvesse uma

\footnotetext{
${ }^{121}$ Idem, pág. 49.

${ }^{122}$ CATTARUZZA, Alejandro. Historia de la Argentina 1916-1955. $2^{\mathrm{a}}$ ed. Buenos Aires: Siglo Veintiuno Editores, 2012, pág. 52.

${ }^{123}$ Comunidade britânica, formada pela Grã-Bretanha e suas então colônias.
} 
solução para o impasse ${ }^{124}$. A Argentina de Yrigoyen se encontrava, como destacado por Arturo O’Connell, em um triângulo econômico mundial ${ }^{125}$.

Tal situação econômica prolongou-se por anos, e se aprofundou após terminada a guerra, sobretudo a partir de 1921, com a brusca queda nas exportações de carne, o que levou muitos criadores de gado, parte tradicional da economia argentina, à crise. Yrigoyen acabou se mostrando ineficiente no trato da questão, deixando-a se prolongar até o término de seu mandato. Em 1922, após seis anos de governo, chegou ao fim o seu governo. Nesta ocasião, sendo o detentor da maior parte das províncias, o radicalismo voltou a triunfar no pleito nacional, e o sucessor de Yrigoyen foi escolhido: Marcelo T. de Alvear. Coube a ele buscar soluções ao impasse econômico e político, e suas ações, fortemente contrárias as de seu antecessor, gerariam uma profunda cisão no seio radical.

\subsection{Do governo do presidente Alvear (1922-1928)}

Máximo Marcelo Torcuato de Alvear, nascido em 4 de outubro de 1868, filho de Torcuato de Alvear, primeiro intendente de Buenos Aires, e neto de Carlos María de Alvear, herói das guerras de independência, descendia de uma das poucas famílias aristocratas argentinas de origem espanhola restantes do período colonial ${ }^{126}$. Seu sangue gotejava fama, riqueza e brilhantismo, e desde o berço aprendeu os finos modos aos quais um homem de sua estirpe deveria primar.

No entanto, anos mais tarde, quis o destino que seus passos se guiassem rumo a um mundo que, por herança progenitora, não orbitara a sua rede de sociabilidade desde o berço: o mundo dos populares. Foi em 1890, durante os acontecimentos que mais tarde viriam a ser conhecidos como Revolução do Parque, que ele calorosamente abraçou esse estranho mundo de pessoas comuns ${ }^{127}$. Durante as grandes manifestações organizadas pela União Cívica, órgão aglutinador dos opositores do governo de Celman, o jovem Marcelo de Alvear encontrou na figura de Leandro N. Alem, o histórico caudilho autonomista, a justaposição do mundo no qual fora criado, o que muito acalentou o seu entusiasmo juvenil, fortemente questionador da ordem da qual descendia.

\footnotetext{
${ }^{124}$ Idem.

125 RAPOPORT, Mario. Historia económica, política y social de la Argentina (1880-2000). Buenos Aires: Ed. Macchi, 2000, pág. 155.

126 LUNA, Félix. Alvear. Biblioteca Argentina de Historia y Politica. Buenos Aires: Hyspamérica Ediciones Argentina, 1986, pág. 17.

${ }^{127}$ Idem, pág. 24.
} 
Desde o estopim das revoltas de 1890, Alvear não mais largou os passos de seu novo mestre inspirador, Alem, e ao seu lado participou da fundação da União Cívica Radical. Bandeirou em inúmeros comícios e campanhas país afora e participou de diversos levantes revolucionários frustrados. Graças a Alem, Alvear, ainda um jovem aristocrata afoito pela causa popular, aproximou-se do grande líder radical depois de Alem, Hipólito Yrigoyen. Com a morte de Alem, e resolvidas as querelas internas ao partido quanto à sucessão da liderança radical, favoráveis a Yrigoyen, Alvear passou a seguir fielmente os caminhos traçados pelo novo líder, e com ele elevou a União Cívica Radical da condição de partido de rua rumo ao papel de grande protagonista político nacional $^{128}$.

Entre 1900 e 1922, Alvear foi deputado nacional e, mais tarde, durante o mandato de Yrigoyen, embaixador argentino na França. Retornando ao seu país a tempo de disputar as eleições presidenciais, Alvear acabou se tornando a escolha certa para a sucessão de Yrigoyen. Como observa Félix Luna, o radicalismo nacional se encontrava nesse momento dividido internamente entre dois grupos: os "azules", ou "galeritas"129, de tendência opositora ao personalismo yrigoyenista, e os "grises", base de apoio do yrigoyenismo $^{130}$.

A postura de Alvear ao longo dos anos, sobretudo durante a sua estada em Paris, sofreu bruscas mudanças quanto à proximidade do anseios mais radicais do partido. $\mathrm{O}$ antigo jovem que marchara inúmeras vezes de peito aberto nas ruas de Buenos Aires sob a liderança de Yrigoyen, cedera lugar a um homem de meia idade afeito à ordem e à preservação das instituições republicanas, por meio do uso do diálogo e da prudência à frente de cargos representativos do país. Essa mudança representou o início do rompimento político de Alvear para com o seu velho líder ${ }^{131}$.

Não obstante, por ora, as aparências se mantiveram e, na inexistência de um candidato à sucessão com temperamento e postura similar a sua, coube a Yrigoyen apostar as suas fichas em seu velho amigo de militância. Em março de 1922, a Convenção

\footnotetext{
128 Idem, pág. 31.

${ }^{129}$ GIACOBONE; GALLO, Idem, pág. 187.

${ }^{130}$ LUNA, Idem, pág. 58.

${ }^{131}$ Félix Luna observa que esse rompimento entre os velhos amigos como a se formar a partir da breve discussão entre os dois à época da decisão de Yrigoyen de manter a neutralidade argentina durante a guerra, posicionamento que discernia da de Alvear, de forte inclinação pró-entente. A discussão, em vez de configurar uma mera oposição em relação a um tema específico, denotava, na realidade, duas visões antagônicas de Argentina: aquela de Yrigoyen, grandiosa, devota da ideia de uma Argentina grande e poderosa internacionalmente, e a de Alvear, pragmática e resoluta quanto a grandes voos diplomáticos que pudessem colocar em apuros a estabilidade econômica e política do país. In Idem, pág. 57.
} 
nacional da UCR reconhecia a candidatura de Alvear, o qual ganharia com grande margem de votos as eleições presidenciais, vindo a assumir o cargo em outubro do mesmo ano $^{132}$.

Novo governo, nova postura. A composição dos ministérios do novo governo serviu para solidificar a mudança de ares planejada por Alvear na condução política do país. De todos os escolhidos para compor o gabinete presidencial, apenas um pertencia ao yrigoyenismo, o ministro de Obras Públicas. Os demais ministérios foram ocupados por políticos proeminentes do radicalismo, ligados aos "azules" antipersonalistas, e também da oposição, em um movimento voltado para a conciliação com os opositores, após anos de duros embates liderados por Yrigoyen. O escolhido para ocupar o Ministério do Interior, poderoso na condução do governo, foi Vicente Gallo, que, ao lado de Leopoldo Melo, encabeçava o antipersonalismo. Dentro da linha conciliadora, Alvear convocou o general Agustín P. Justo para comandar o Ministério da Guerra ${ }^{133}$.

Iniciativas de controle dos gastos públicos e dinamização da economia argentina logo foram levadas a cabo por Alvear. Assim, restringiu ao longo de seu governo a criação de novos cargos públicos, além de extinguir aqueles considerados ociosos e/ou desnecessários para a máquina pública, resquícios do período yrigoyenista, em que a distribuição de cargos públicos atendia às demandas políticas do governo federal. Seu método de governabilidade se baseava, portanto, em premissas essencialmente contrárias ao de seu antecessor: ao Presidente da República caberia o encaminhamento das atividades lideradas por seus ministros, dentro de uma linha claramente britânica de governo, e não a liderança unilateral do governo, como tão predicada por Yrigoyen ${ }^{134}$.

Em 1924, ocorreu um grave cisma no seio da UCR: o antipersonalismo, até então engajado em solapar a liderança interna dos yrigoyenistas, decidiu se desvencilhar e constituir partido político próprio para as eleições deste ano, surgindo assim a União Cívica Radical Antipersonalista. O ministro do Interior, Vicente Gallo, foi o principal motivador da cisma, e buscou animar o presidente Alvear para seguir os seus passos, pois

\footnotetext{
132 Idem, pág. 59.

${ }^{133}$ Idem, pág. 61. A primeira escolha de Alvear foi o nome do general José Félix Uriburu, general com quem mantinha, já a muitos anos, relações amistosas. No entanto, foi aconselhado a mudar de opção, devido à postura germanófila de Uriburu, o que não poderia agradar nações como Inglaterra e França, recém vencedoras de uma sangrenta guerra contra justamente a Alemanha. Justo, por outro lado, representava a tradição anglófona da marinha argentina, além de conter todos os demais pré-requisitos necessários para o cargo. De todo modo, a escolha de um nome forte do Alto comando das Forças Armadas para o comando do Ministério da Guerra transmitiu uma boa e receptiva imagem para os militares, até então descontentes com os rumos predicados por Yrigoyen.

${ }^{134}$ SABSAY, Fernando L; ETCHEPAREBORDA, Roberto. El Estado Liberal Democrático. Buenos Aires: Ed. Eudeba-Macchi, 1987, pág. 210.
} 
o seu rompimento com o personalismo yrigoyenista já era evidente. No entanto, a fidelidade partidária, suscitada talvez por velhas lembranças dos tempos de marchas e revoltas ao lado de Leandro Alem e de Yrigoyen, em seus tempos de profunda amizade, em nome da UCR, calou o ímpeto por autonomia que tremulava no íntimo de Alvear.

Apesar da negativa, o presidente não demitiu Gallo do cargo, como convinha a prudência, e essa atitude, mais uma vez, foi considerada um ato de rebeldia declarada à Yrigoyen $^{135}$. A situação apenas de apaziguou levemente em julho de 1925, quando Gallo renunciou ao ministério, após a negativa de Alvear em permitir uma intervenção na província de Buenos Aires, algo que era suscitado por Gallo em sua estratégia, à moda yrigoyenista, de intervir politicamente em províncias controladas por opositores ${ }^{136}$.

Com a demissão de Gallo em meados de 1925, e a relação conturbada com o personalismo, que saíra amplamente vitorioso das eleições de 1924, garantindo maioria na Câmara dos deputados, o presidente Alvear se viu em meio a um fogo cruzado que poderia minar as bases de seu governo, que ainda tinha muitas políticas importantes a serem colocadas em pauta, o que demandaria apoio do Congresso. Os antipersonalistas, propensos ao alinhamento com os demais políticos conservadores e com os radicais dissidentes de origem bloquista e lencinista, começavam a olhá-lo com certa distância, enquanto o personalismo já não mais acreditava em seus intentos havia muito tempo ${ }^{137}$.

Dentre as medidas necessárias a serem adotados por Alvear, destacava-se, ainda na transição de governo em 1922, a solução para a crise econômica em marcha desde 1917, e agravada um ano antes, com os impasses entre Argentina, Inglaterra e Estados Unidos. Porém, com a retomada do crescimento de parte da Europa e o aumento da demanda pelas exportações de carne e cereais argentinos, além da dinamização da produção industrial nacional, logo o país voltou a conhecer um novo, e ligeiro, período de prosperidade econômica e social, que se desenrolaria de 1923 até 1929, ano da grande crise $^{138}$. Esses anos, conhecidos como "breve era de ouro", coincidiram com o governo de Alvear, o que, a parte as disputas políticas acirradas entre os partidos, colaborava por manter a opinião pública em calmaria.

Todavia o crescimento econômico, que postergou por mais alguns anos a importante discussão acerca das parcerias econômicas do país, o governo de Alvear

\footnotetext{
135 ROMERO, Idem, pág. 57.

${ }^{136}$ Idem.

${ }^{137}$ SABSAY; ETCHEPAREBORDA, Idem, pág. 212.

${ }^{138}$ Idem, pág. 209.
} 
seguiu, em seus anos finais, empacado pela falta de maioria no Congresso, o qual se encontrava visivelmente dividido. Os partidos tradicionais, o Conservador e o Liberal, mantinham suas bases de apoio em algumas províncias do interior, últimos baluartes da velha ordem liberal-conservadora. No campo nacional, no entanto, digladiavam-se os personalistas da União Cívica Radical, que formavam a maioria, os deputados da União Cívica Radical Antipersonalista, os mais próximos de causar incômodo aos primeiros, e os membros do Partido Socialista, que, para realçar o tabuleiro, sofreu uma cisão em 1927, que veio a dar origem ao Partido Socialista Independente, de tendência antiyrigoyenista $^{139}$.

Somado ao intricado jogo de interesses que moviam o tabuleiro político, encontrava-se, como já demonstrado anteriormente neste capítulo, a atividade dos nacionalistas. Sua visão, apesar de amplamente heterogênea, coadunava-se em torno de uma perspectiva em comum: seus anseios e projetos não encontravam medida em nenhum dos partidos políticos existentes no país, pois o que pretendiam inaugurar na Argentina era de tal modo inovador e radical, em sua visão, que nenhuma bandeira política conseguiria resistir aos ventos por eles vislumbrados. Como sinaliza o historiador brasileiro José Luis Beired, em um estudo comparativo do nacionalismo praticado no Brasil e na Argentina nas primeiras décadas do século XX, a autoimagem que os intelectuais nacionalistas faziam de si próprio estava carregada de uma forte visão de salvacionismo nacional ${ }^{140}$.

No fim de seu governo, por volta de 1927, uma questão herdada dos tempos de seu antecessor voltou a suscitar os ânimos populares. Tratou-se da exploração do petróleo do território argentino, discussão que abarcava duas visões díspares: a primeira, criada e liderada por Yrigoyen, em consonância com sua visão estatizante, defendia que todas as reservas nacionais de petróleo deveriam ficar a cargo da YPF (Yacimientos Petrolíferos Fiscales), uma empresa estatal criada em meados de 1922 por ele próprio, e que estava a cargo do militar Enrique Mosconi, de forte tendência radical. Já a segunda visão, de ampla aceitação entre os aliados de Alvear e a oposição, primava pela livre-iniciativa e a exploração das reservas por petrolíferas estrangeiras ${ }^{141}$.

\footnotetext{
${ }^{139}$ DI TELLA, Idem, pág. 170.

${ }^{140}$ BEIRED, José Luis Bendicho. Sob o signo da nova ordem: Intelectuais autoritários no Brasil e na Argentina. São Paulo: Ed. Loyola, 1999, p. 61.

${ }^{141}$ ROCK, David. Argentina 1516-1982: from spanhish colonizacion on the falklands war. Berkeley: Univ. California, 1985, pág. 209.
} 
O debate em torno do petróleo ganhou as páginas de jornais, revistas ilustradas, memorandos diplomáticos e logo se tornaria a pedra angular da UCR durante a campanha eleitoral de 1928. Essa discussão também envolveu os interesses de petrolíferas estrangeiras, como a britânica Shell e a norte-americana Standard Oil, que já atuavam em pleno vapor a alguns anos em solo argentino dentro das reservas que não estavam sob controle da YPF, e agora temiam perder os seus investimentos caso todo o petróleo argentino passasse a ser controlado exclusivamente pela estatal ${ }^{142}$.

O espectro de Yrigoyen esteve presente em todos os 6 anos de governo do presidente Alvear. Desde a composição controversa de seu gabinete, ainda nos primeiros dias de governo, até a inércia, encarada pelos yrigoyenistas com uma verdadeira indiferença em relação aos interesses do partido, representada por Alvear frente ao cisma antipersonalista, demonstraram aos personalistas que a eleição de Marcelo Alvear fora um verdadeiro desastre para a continuação das políticas iniciadas na gestão de Yrigoyen.

No entanto, o governo de Alvear não deve ser encarado como um mero período tampão da era radical, sem características próprias e importância para o desenrolar da história política argentina nesse período. Pelo contrário, o período 1922-1928 foi marcado por importantíssimas discussões para a política nacional. Do ponto de vista político, colocou-se em xeque a unidade da UCR por meio da cisma de 1924 e da dinamização da oposição política ao yrigoyenismo. Já do ponto de vista econômico, a Argentina conheceu durante esses anos uma certa pujança de inversões e a entrada de grandes montas de capital, o que assegurou a prosperidade econômica necessária para a manutenção da paz social.

Em meio a tudo, deve-se considerar as fortes atitudes por parte de Alvear, que manteve sua postura de governo frente às investidas do personalismo e da oposição da melhor forma possível, garantindo que as tensões outrora existentes entre diferentes instituições da República (governo, partidos, Forças Armadas) fossem apaziguadas pelas medidas conciliadoras tomadas em sua gestão ${ }^{143}$. O término dela tornou pública a sua separação do personalismo yrigoyenista, ao não indicar candidatos para a sucessão e se quer oferecer ajuda para a escolha do próximo candidato do partido. Aliás, dada a sua larga experiência, ele já sabia que o destino político da UCR era inevitável e a próxima indicação não passaria por outro nome que não fosse o de Hipólito Yrigoyen.

\footnotetext{
142 ROMERO, Idem, pág. 59.

${ }^{143}$ SABSAY; ETCHEPAREBORDA, Idem, pág. 213.
} 
3. O Jornal La Nación e a Intervenção militar de 1930 
Entre 1928 e 1930, deu-se ação um dos momentos mais turbulentos da história política moderna argentina. Conforme exposto nos capítulos anteriores, desde os seus primórdios o Estado argentino foi alvo de inúmeros instantes de caos e embates políticomilitares. No entanto, ao menos desde 1890, ano da Revolução do Parque, todas as tentativas de sublevação popular contra o governo amparadas pelas forças armadas ou por grupos armados individuais foram rechaçadas com certo sucesso ainda em seu início.

A causa principal por detrás das tentativas de derrocada de governos eleitos no período de hegemonia autonomista foi a legitimidade dos governantes em voga e do sistema eleitoral vigente. O principal protagonista e cabeça-chave nos ocasos revolucionários deste período foi a União Cívica Radical, liderada pelo carismático Hipólito Yrigoyen. Suas reivindicações políticas miravam, quase sempre, a inexistência de transparência nos pleitos eleitorais realizados país afora e, sobretudo, a perpetuação no poder de grupos minoritários das elites políticas e econômicas ocasionada pelas fraudes eleitorais institucionalizadas, em detrimento da maior parcela da sociedade.

No ano de 1912, chegou-se a uma possível solução para o velho impasse que tornava dissonantes os passos tomados pela UCR e demais grupos representativos do autonomismo. Com a assinatura da Lei Sáenz Peña, um novo horizonte de perspectiva se abria para o jogo político nacional, uma vez que o sufrágio eleitoral masculino dava esperança de representação política aos grupos médios urbanos, até então alejados do poder central. Em 1916, a UCR, amparada pela maior parte do eleitorado, conseguiu eleger Hipólito Yrigoyen à Presidência da República, dando início à era radical.

Conforme já apresentado, o período 1916-1928 foi amplamente dominado pelos líderes políticos radicais, divididos em dois grandes grupos, os personalistas e os antipersonalistas. Os primeiros formavam a base de apoio de Yrigoyen e seus aliados, e assim eram chamados por identificarem a existência da UCR à personalidade e carisma pessoal de Yrigoyen. Já o segundo grupo discordava da primeira visão e encaravam a UCR como um grupo político amplo e heterogêneo que encontrava legitimidade na ação de inúmeras facções internas e de seus representantes, e não somente na persona de uma única personagem.

O principal representante do grupo antipersonalista foi Marcelo T. de Alvear, que jamais aceitou sair da UCR, da qual era um expoente e que mantinha fortes laços laços de parentesco e pertencimento para com os grupos aristocráticos portenhos. Forte opositor 
de Yrigoyen, Alvear chegou à presidência em 1922, após o término do primeiro mandato de seu oponente. Seu tímido governo se denotou pela busca de abertura de diálogo da UCR para com grupos dissidentes e opositores, os quais foram fortemente repelidos pela atitude centralizadora de Yrigoyen.

No entanto, a sombra de seu oponente político ofuscou todas as suas tentativas de desmantelamento do personalismo radical e da criação de redes de alianças para com os demais partidos de oposição. Em 1924, alguns líderes antipersonalistas, dentre eles Leopoldo Mello e Vicente Gallo, se desvencilharam da UCR e fundaram a União Cívica Radical Antipersonalista. Mais tarde, ambos pleitearam a presidência contra Yrigoyen, não angariando sucesso em sua empreitada. O resultado foi a reeleição de Hipólito Yrigoyen à Presidência da República nas eleições de $1928^{144}$.

O retorno de Hipólito Yrigoyen foi observado com séria desconfiança por parte dos principais grupos políticos hegemônicos. O medo do retorno das políticas centralizadoras de seu primeiro mandato, cristalizadas nas intervenções federais feitas pelo governo central sob a retórica do apaziguamento regional, não obstante as muitas denúncias de favorecimento de grupos pró-Yrigoyen nas províncias em questão, e dos novos direcionamentos econômicos e diplomáticos a serem formulados produziram uma elevada verborragia antiyrigoyenista, a qual se alastrou pela imprensa nacional.

Dentre os múltiplos veículos de imprensa opositores, alguns destes brevemente citados no capítulo anterior, destacou-se a ação do jornal diário La Nación. Desde a ascensão do radicalismo na política nacional, o jornal mostrou-se rigidamente cético em relação aos novos horizontes políticos mirados, em especial no que consta à figura de Yrigoyen. Se durante o governo Alvear o jornal buscou amenizar seu espírito opositor, a partir de 1927, com o início da corrida eleitoral à presidência e o retorno de Yrigoyen ao escopo da esfera política, o La Nación voltou a cerrar fileiras ante o despontar do personalismo radical.

Neste capítulo, analisar-se-á os posicionamentos adotados pelo jornal La Nación em relação ao segundo mandato de Hipólito Yrigoyen e às principais questões que agitaram seus dois anos de governo. O estudo aqui oferecido se baseou nas informações coletadas a partir da análise das capas e editoriais publicados pelo jornal entre 1928 e

\footnotetext{
${ }^{144}$ A eleição presidencial de 1928 foi antecedida pelas eleições provinciais.
} 
1930, os quais oferecem perspectivas globais acerca do pensamento segundo o qual se rege o jornal. ${ }^{145}$

\subsection{As eleições de 1928 e o ressurgimento de Hipólito Yrigoyen}

O ano de 1928 teve início de modo nada peculiar nas páginas do jornal La Nación: entre fotografias de personalidades públicas e propagandas das últimas grandes inovações do mundo industrial, o jornal estampava em suas páginas as últimas informações adquiridas da situação política na província de Tucumán. Ali ocorrera uma série de embates no dia anterior entre simpatizantes do personalismo e do antipersonalismo radical, pois as movimentações em torno das novas eleições nacionais e provinciais começavam a tomar forma país afora ${ }^{146}$.

As eleições de 1928, devido às suas especificidades, exigiram uma intensificação das análises políticas por parte dos editoriais do jornal La Nación, então dirigido por Jorge e Luis Mitre, netos do fundador Bartolomé Mitre e grandes personalidades públicas nacionais, seguidores do posicionamento liberal que marcou a trajetória de seu avô. A Argentina experimentava, no período 1927 e 1928, o início da retração econômica, oriunda da perda de mercados para a carne argentina na Europa e do aumento do endividamento público, em alta desde $1916^{147}$, o que de fato explodiria em fins de 1929 , com a crise econômica norte-americana começando a se globalizar.

As eleições presidenciais ${ }^{148}$ ocorreram ao longo do primeiro semestre de 1928, e foram acompanhadas com grande ansiedade e expectativa por parte do La Nación e de outros grandes veículos de imprensa nacionais. Os principais partidos concorrentes ao mais alto cargo da nação eram a União Cívica Radical, a União Cívica Radical Antipersonalista, apoiado pela Confederação das Direitas, e o Partido Socialista Independente.

\footnotetext{
${ }^{145}$ As edições impressas do jornal La Nación, publicadas entre 1928 e 1930, foram inquiridas e selecionadas a partir de análise in loco dos arquivos microfilmados sob a guarda da Sala de Microfilmes da Biblioteca do Congresso argentino, presente na cidade de Buenos Aires - Argentina.

${ }^{146}$ La Nación, Buenos Aires, 01 jan 1928, p. 7.

147 RAPOPORT, Mario. Historia económica, política y social de la Argentina (1880-2000). Buenos Aires: Ed. Macchi, 2000, pág. 149.

${ }^{148}$ As eleições presidenciais na Argentina eram indiretas, ou seja, primeiramente era formado, a partir do voto direto, um colégio eleitoral, para então se eleger a presidência da república. Também ocorriam, concomitantemente à eleição presidencial, as eleições para o cargo de governador das províncias do interior. Havia ainda, a cada dois anos, eleições para a Câmara dos Deputados, com recomposição de metade da Casa a cada pleito bianual, para mandatos de 4 anos, e eleições para o Senado, para mandatos de 6 anos. No período aqui analisado (1928-30), houve eleições para a Câmara dos Deputados (1928 e 1930) e para o Senado (1928), além da própria Presidência da República e Províncias (1928).
} 
Durante as campanhas eleitorais, o La Nación manteve diariamente uma coluna específica para tratar das atividades políticas na capital Buenos Aires e no interior. Nessa coluna, no dia 5 de janeiro, o jornal anunciava que a União Cívica Radical Antipersonalista lançaria a candidatura de seus dois fundadores, Leopoldo Melo e Vicente Gallo, para a presidente e vice-presidente da República, respectivamente ${ }^{149}$. No entanto, o lançamento da candidatura, como se apresentava, necessitaria do apoio dos partidários espalhados pelas demais províncias, o que ainda não estava concretizado, como dá a entender o jornal ao proferir que "Algunos políticos se manifestan pesimistas, creyendo inminente una ruptura definitiva" ${ }^{\prime 50}$.

Ao passo que a UCR Antipersonalista fora a primeira sigla a lançar os seus presidenciáveis, os demais partidos, em especial a UCR personalista, ainda faziam mistério quanto ao seu futuro político. Afinal, a UCR ainda estava no poder, e dada a clara tensão entre yrigoyenistas e alvearistas, seguidores do presidente Alvear, especulava-se que o novo candidato, caso pertencesse ao primeiro grupo, não receberia adesão pública por parte deste. O La Nación, frente ao iminente fim do governo de Alvear, buscou refletir, em seus editoriais diários, as principais questões que ainda se faziam pendentes relativas ao atual governo e que, por conseguinte, que se manteriam irresolutas até que um novo presidente fosse empossado.

Em um dos mais enfáticos editoriais do período de campanhas de 1928, é apresentada uma análise sucinta e pormenorizada do período radical segundo a visão do jornal, onde se argumentava a mudança significativa ocasionada pela gestão Alvear em relação a de Yrigoyen. Pode-se perceber, a partir da leitura do texto, que, pelas entrelinhas da análise, suscita uma tendência crítica latente em relação ao yrigoyenismo e a sua herança para a democracia argentina. Na realidade, como o leitor poderá observar, as críticas ao yrigoyenismo são evidentes e claras. Pela sua importância analítica, destacamos grande parte do texto do editorial logo abaixo:

"La conquista del poder por el Partido Radical significó hace doce años la promesa de un cambio de métodos políticos. Los miembros de la populosa agrupación (...) ofrecian la perspectiva de una evolución democrática transcendental en la vida política argentina (...) Al terminar, empero, ese ensayo de radicalismo genuíno, muchos de sus partidários se habian llamado ya a engaño, así como la totalidad de los simpatizantes de la primera hora. Otros, en cambio, aumentaron el acervo del jefe del partido. De ese modo su fuerza no disminuyó en

${ }^{149}$ La Nación, Buenos Aires, 05 jan 1928, pág. ?
${ }^{150}$ Idem. 
realidad y su poder electoral se mantuvo enhiesto hasta el punto de hacer posible y visible una segunda presidencia radical. Pero ésta no siguió las aguas de la primera. Marcó, sin duda alguna, por el contrário, uma reacción eficaz contra ella, así en los métodos políticos como en el respeto a las instituciones y en la restauración del orden administrativo, tan efectivamente desmedrado por el primer gobierno del partido. Todo ello, unido a la falta de conformidad con el jefe de éste en la dirección del mismo, dió motivo a uma corriente de desintegración. Se formó así el antipersonalismo (...) Ese movimiento de opinión congregó en sus filas a todos los descontentos de la jefatura radical y a los miembros de los demás partidos (...) Desde luego, salta a la vista la exitencia en toda la República de agrupaciones políticas no radicales, ni por su origen, ni por su tradición, ni por la actuación de sus hombres directivos. So han mobilizado, empero, en su casi totalidad para plegarse a la actitud del núcleo radical gobernante frente al jefe de la rama de la agrupación y candidato tácito por segunda vez a la presidencia (...) Los candidatos antipersonalistas no son en realidad candidatos oficiales sino muy relativamente. Apoyan, ellos y su partido, a la presidente actual. No están, en cambio, apoyados por ella (...) A esse respecto, evidentemente la presidencia no está embarcada en esa política ni em política alguna (...) Hemos fijado más de una vez nuestro juicio sobre el primer gobierno radical. Nunca hicimos reserva de nuestra censura ante muchos de sus actos. La segunda presidencia nos movió a veces al aplauso, sin dejar tampoco de provocar alguna vez nuestra honrada disidencia (...) ${ }^{151}$ (Meus grifos)

O longo trecho acima destacado alude a algumas das características da realidade política nacional. O editorial é direto em sua oposição ao primeiro governo radical encabeçado por Yrigoyen, e destaca, com aparente surpresa, que o governo de Alvear claramente se distanciou daqueles que teriam sido os principais vícios do seu antecessor. Ao atual governo, o jornal logra o êxito pelo respeito às instituições políticas e pela restauração da ordem política, tão desvalorizados, destaca, pelo seu antecessor. O claro distanciamento verificado entre Alvear e Yrigoyen entre 1922 e 1928 levou ao surgimento, como já explicado anteriormente, e aferido pela fonte aqui apresentada, do antipersonalismo, que surge como uma opção tanto para radicais descontentes com Yrigoyen, quanto para opositores alejados do poder já a um bom par de anos. E encerra o editorial afirmando que suas reservas a Yrigoyen jamais foram veladas, em consonância com seu apoio, cada vez mais evidente, a Alvear e ao candidato que confrontar a fórmula personalista.

A partir do trecho extraído, evidencia-se a forma como o editorial buscava lidar com seus posicionamentos políticos: sempre de forma direta e evidente ao seu leitor

\footnotetext{
${ }^{151}$ Editorial "La renovación presidencial”. Idem, 17 jan 1928, pág. 6.
} 
habitual. Esse editorial permite observar, ainda, um trajeto inexorável a todos os opositores de Yrigoyen, e que se evidenciaram nos dias seguintes: o apoio total ao candidato antipersonalista, único capaz de fazer frente ao avanço "tácito" do líder radical. No entanto, como destacado, a falta de apoio por parte do presidente Alvear, o que se verificará ao longo de toda a campanha, poderia causar danos à frente opositora na sua caça junto ao colégio eleitoral a ser constituído ${ }^{152}$. Sua adesão não oficial ao antipersonalismo se evidencia no fato de que a cobertura dos presidenciáveis deste partido teve maior repercussão nas páginas diárias do jornal do que a dos demais partidos, à exceção de uma cobertura ampla, porém tendente à visão crítica, dos rumos eleitorais tomados pela UCR.

Em meio às indefinições eleitorais, poucos dias após a oficialização da fórmula presidencial antipersonalista Melo-Gallo, como se popularizou chamá-la, o jornal destacava a adesão a ela de políticos liberais e conservadores, que ainda eram fortes em determinadas províncias do interior. Essa adesão em massa que começava a se formular fora denominada Confederação das Direitas. No entanto, devido à histórica divergência entre mitristas (liberais) e autonomistas (conservadores), a frente única acabou por ser renegada por muitos eleitores de ambas ideologias, os quais ameaçavam lançar os seus votos sobre o candidato personalista ${ }^{153}$. Apesar da aparente contradição, a ameaça amealhada pelos opositores da frente única das direitas traz a luz algo que já incomodava parte das elites políticas nacionais: para muitos simples eleitores provincianos, a política a nível nacional simplesmente não lhes incomodava diretamente. Muitos desses eleitores e políticos que fizeram frente à Confederação das Direitas foram expurgados de seus partidos.

Uma notícia que ganhou notoriedade foi a denúncia perpetrada pelo Ministro de governo da província de Santa Fé relativa a um suposto ataque armado planejado por forças personalistas, com o apoio de policiais, a partir da província de Buenos Aires em regiões onde a vitória da oposição era estimada em Santa Fé ${ }^{154}$. O estado de tensão política começava a ganhar força em níveis nacionais, colocando o país em alerta constante. Diversos confrontos entre militantes personalistas e antipersonalistas foram

\footnotetext{
${ }^{152}$ Editorial "El gobierno y la Formula Melo-Gallo". Idem, 19 jan 1928, Capa.

${ }^{153}$ Editorial “Algunos liberales de Corrientes se inclinaran hacia el Personalismo”. Idem, pág. 8.

${ }^{154}$ Editorial "Una grave denuncia contra los personalistas de Buenos Aires". Idem, 21 jan 1928, pág. 3; Editorial "Una denuncia gravíssima”, 23 jan 1928, pág. 4.
} 
verificados nas semanas seguintes, muitas vezes envolvendo forças policiais de diferentes províncias $^{155}$.

Além dos casos de choques entre grupos políticos rivais, também foram verificadas, nesse início de campanha, diversas queixas por parte dos dois grupos radicais envolvendo denúncias de fraudes eleitorais em encaminhamento. Em todos esses momentos, a figura do Poder Executivo nacional, envolto de neutralidade primaz, fora evocada por ambos os grupos, em clara tentativa de angariar legitimação as suas reivindicações.

Duas importantes adições à fórmula antipersonalista foram oficializadas em 22 de janeiro: o Lencinismo de Mendoza e o Bloquismo de San Juan. Ambas facções radicais já haviam se afastado de Yrigoyen desde meados de 1922, quando o mesmo decretou duas intervenções federais sobre essas províncias a fim de controlar o crescimento eleitoral da família Lencinas e da família Cantoni. A oficialização do apoio se deu durante uma assembleia antipersonalista na capital da província de Mendoza, território lencinista, a qual foi referendada pelo La Nación como "una de las más expressivas manifestaciones cívicas que se recuerden en la capital andina" ${ }^{\prime 56}$.

Nesta ocasião, estiveram presentes Carlos W. Lencinas, chefe político do lencinismo, e Federico Cantoni, chefe político do bloquismo, que em seu discurso relembrou os processos eleitorais fraudulentos do período autonomista, e defendeu que a chegada de Yrigoyen ao poder em 1916 fora um grande passo para a democracia argentina, ainda que “(...) nada le pudimos reprochar, ya que el hombre no tenia programa" e continuou "Hoy estamos frente a nuevos métodos, ante hombres que como los otros también recorren el pueblo del país, pero no para huir de nadie, sino para buscar en cada provincia sus necesidades. ${ }^{157}$. A assembleia foi finalizada com grande êxito e em meio às palmas e gritos do povo, sobretudo quando da contundente, e superestimada, afirmação do orador: “(...) tanto el lencinismo como el bloquismo son agrupaciones invencibles (...)" ${ }^{\prime 158}$.

\footnotetext{
${ }^{155}$ Em 23 de janeiro, o jornal apontava um radical personalista como o responsável por matar a tiros dois militantes antipersonalistas durante uma conferência organizada pela frente única de oposição na província de Santa Fé. Somente na província de Córdoba, fora registrado dois motins, um envolvendo um tiroteio entre personalistas e democratas, e o outro, dois dias depois, entre personalistas e membros da polícia local. Muitos personalistas de Córdoba, entretanto, acusaram o governo local de persegui-los, o que levou, dias mais tarde, à elaboração de um diálogo pacífico entre as duas partes. Muitos outros casos de violência foram registrados nos dias posteriores. Idem, pág. 6; Idem, 24 jan 1928, pág. 6; Idem, 25 jan 1928, pág. 8.

${ }^{156}$ Idem, 23-01-1928, pág. ?

157 Idem.

158 Idem.
} 
Em meio a uma onda de violência eleitoral crescente, com tiroteios e mortes envolvendo praticamente todas as edições diárias do jornal, em 6 de fevereiro era decretado o primeiro grande resultado das eleições provinciais para formação do Colégio eleitoral: os personalistas venceram com uma diferença de 2.500 votos a oposição ${ }^{159}$, fato que foi recebido com alguma, mas não total, surpresa pelo jornal ${ }^{160}$. Não obstante a derrota eleitoral, a oposição ainda permanecia confiante nos rumos futuros. Observada a derrota, um senso de urgência se abateu sobre os demais partidos da frente única, que decidiram ratificar imediatamente a adesão dos partidos provinciais à fórmula antipersonalista. Ratificaram a adesão os representantes de todas as províncias argentinas ligados ao Partido Liberal, Partido Conservador, Partido Autonomista e Partido Democrata $^{161}$. O objetivo, claramente, era unir a todos os inimigos de Yrigoyen sob uma mesma bandeira, pois, como esclareceu o manifesto antipersonalista "el supremo deber del momento es impedir el funesto retorno del sistema que practica el personalismo irigoyenista" ${ }^{162}$.

Somente em 25 de março veio a se conhecer, oficialmente, a fórmula presidencial da União Cívica Radical, que seria composta por Hipólito Yrigoyen e Francisco Beiró, seu provável candidato a vice-presidente, não obstante o seu estado de saúde, que gerava grande consternação em meio à liderança personalista ${ }^{163}$. Tomada a decisão do partido, poucos dias antes das eleições presidenciais, coube ao presidente Alvear exortar os partidos ao respeito mútuo e às instituições republicanas ${ }^{164}$.

O La Nación, com sua usual sinceridade editorial, ao analisar as eleições que se realizariam em poucos dias, reconheceu que a vitória do personalismo já era dada como certa, tendo em conta as sucessivas derrotas da oposição em províncias chaves:

Hemos de creer que sí el poder electoral se pronuncia el domingo en uma forma concordante con los indicios a que ya nos referimos, es porque confía en que el jefe personalista habrá de rectificar algunas de las práticas gubernativas reveladas en su administración anterior. Excusado es decir cuánto deseamos también que, si el caso llega, su gobierno así lo demuestre. Mas, entretanto, pecaríamos por falta de sinceridad si no agregásemos que el triunfo de la respectiva fórmula

\footnotetext{
${ }^{159}$ Capa “La U.C.R. Personalista triunfó en las elecciones de Santa Fé”. Idem, 06 fevereiro 1928, pág. 6.

${ }^{160}$ Editorial "El momento político". Idem, 09 fevereiro 1928, pág. 6.

${ }^{161}$ Capa "Los partidos de la derecha han ratificado su adhesion a la formula Melo-Gallo". Idem, 11 fevereiro 1928.

162 Capa. Idem, 14 fevereiro 1928.

${ }^{163}$ Capa. Idem, 25 março 1928.

${ }^{164}$ Carta aberta "El Dr. Alvear ante la eleccion de su sucesor: una exhortación al respecto mutuo", 30 março 1928, capa.
} 
robustecería, por de pronto, no pocos receios. El Partido Radical personalista va nuevamente, en efecto, a una elección presidencial sin otro programa que el de "evangelizar con la Constituición". 165

A clareza da crítica acima demonstra o principal receio do jornal em relação a um possível novo governo de Hipólito Yrigoyen: a inexistência de clareza quanto às principais questões que agitavam o país, sobretudo no campo da economia, e também no trato com a burocracia administrativa. Ao reconhecer a derrota iminente do antipersonalismo, o jornal reitera, não obstante, a defesa da democracia e da soberania das urnas, deixando nas mãos do povo a escolha do novo líder. Em $1^{\circ}$ de abril se realizaram as eleições presidenciais, que deram ampla vitória para o personalismo radical, assegurando um novo mandato a Yrigoyen. Muitos militantes radicais passaram a chamar essas eleições de "plebiscito", pois consideravam que a vitória yrigoyenista já havia sido referendada pelo povo muito antes, o que, de fato, foi demonstrado nas urnas.

No entanto, a vitória dos personalistas não foi tão devastadora no Congresso nacional. Há medida que os resultados foram sendo escrutinados pelas juntas eleitorais, percebeu-se que a oposição, isto é, antipersonalistas e confederação das direitas, somados a quantidade de cargos conquistados, se saíram melhores do que esperavam. A maioria personalista na Câmara dos deputados voltou a se repetir, como no primeiro governo de Yrigoyen, no entanto, a minoria oposicionista estaria representada em bom número, de modo a conseguir causar elevados danos à base governista.

Já no Senado, logo se vislumbrou o cenário já esperado, com maioria opositora, o que se mostraria nos dois anos seguintes um verdadeiro empecilho para os desígnios do novo presidente. Em coluna assinada por José Nicolas Matienzo, famoso constitucionalista e professor de direito da Universidade de Buenos Aires, antigo ocupante dos cargos de Procurador Geral da Nação, durante o primeiro governo radical e de Ministro do Interior, no governo de Alvear, e recém eleito Senador nacional pela província de Tucúman, cargo que ocuparia até a sua morte em 1936, resumia o atual estado político pós-eleições.

No trecho abaixo, Matienzo começa por definir o principal erro cometido pela oposição, em sua opinião:

(...) en la campaña electoral que acaba de terminar, han dedicado sus esfuerzos a conquistarse la buena voluntad del Presidente y de los gobernadores, en vez de empeñar sus esfuerzos en la

\footnotetext{
${ }^{165}$ Editorial “Las elecciones del domingo”. Idem, 30 março 1928, pág. 6.
} 
conquista del afecto popular. Fruto del mismo error es su enojo contra los funcionarios ejecutivos que no han contrarrestado por procedimientos regales los resultados del voto secreto, es decir, que no han adulterado el libro sufragio ${ }^{166}$

E complementa, com tom premonitório, que o retorno de Yrigoyen não encontrará a mesma receptividade de outrora, quando em 1916 assumiu o poder presidencial envolto em grandes expectativas, pois, após anos de controle personalista, a oposição voltara se congregar em uma única frente, capaz de dissuadir o governo de atitudes centralizadoras e autocráticas:

¿Están preparadas y dispuestos los vencedores y vencidos del $1^{o}$. de abril a desempeñar debidamente en el Parlamento argentino su respectivo papel en el gobierno de discusión que la República piede? (...) Es de esperar que todos cumplan sus deberes constitucionales: el partido dominante iniciando las medidas del interés general(...) la oposición fiscalizando con altura la conducta del nuevo gobierno. ${ }^{167}$

Passados poucas semanas da vitória eleitoral, logo o personalismo começou a sofrer os seus primeiros embates. A saúde do vice-presidente eleito, Francisco Beiró, havia se debilitado enormemente em poucos dias, e a oposição começara a questionar se o mesmo seria capaz de tomar posse ${ }^{168}$. Ocorre que a Constituição nacional, e mesmo a Lei eleitoral, não deixavam claro quais caminhos se deveriam percorrer em caso de falecimento de um vice-presidente eleito ainda não empossado. A situação em torno de Beiró ocorreu simultaneamente a um novo entrave entre personalistas e oposição no Congresso, pois os deputados personalistas passaram a defender que os diplomas dos parlamentares eleitos pela província de Mendoza, e mais tarde também de San Juan, não deveriam ser aceitos pelo parlamento, devido à supostas falhas eleitorais registradas ${ }^{169}$.

O problema dos diplomas atingiu o Senado, que logo se viu dividido em infindáveis discussões acerca da questão. Em meio a essas querelas, o La Nación, por meio de seus jornalistas investigativos, apurara que, desde os bastidores políticos do Senado, já se ouvia a crítica de que a impugnação dos diplomas perpetradas pelos personalistas buscava atingir a oposição interna da UCR, uma vez que os diplomas pertenciam, dentre outros, aos senadores eleitos Carlo W. Lencinas e Federico Cantoni ${ }^{170}$.

\footnotetext{
${ }^{166}$ Editorial “Gobierno, oposicion y critica”. Idem, 23 maio 1928, pág. 6.

${ }^{167}$ Idem.

${ }^{168}$ Capa "La salud del Dr. Beiró". Idem, 06 junho 1928.

${ }^{169}$ Capa, "Los otros diplomas". Idem, 06 junho 1928.

${ }^{170}$ Capa, "No ha variado la situación en el Senado Nacional". Idem, 01 junho 1928.
} 
A influência dos ramos yrigoyenistas sobre os rumos do Congresso já era evidente, ainda que o seu líder não estivesse oficialmente empossado. Para o La Nación, urgia à soberania e pacificação do legislativo nacional uma atitude refreadora por parte do ainda presidente Alvear e em relação aos avanços do personalismo:

Los sucesos parecen indicar que el periodo del Dr. Alvear no terminará bajo auspicios felices para la normalidad republicana. Porque un partido (...) se pretende poner en cuestión todo el orden institucional. (...) La mayoría ha elegido sus representantes: eso es todo. Sus conquistas corresponden exactamente a su fuerza, de acuerdo con las previsiones de la ley. Debería limitarse a gobernar dentro de sus medios. Pero quiera más: quiere el total alianamiento de los obstáculos legales que puedan oponérsele, para que no existan ni indicios de fiscalización (...) en el escenario nacional se desarrollan episodios subversivos cuya consecuencia seria la organización de un doble Senado. Nada parecen valer las objeciones de orden constitucional ante la doctrina demagógica de los derechos implicitos de las mayorias. ${ }^{171}$

Em 23 de julho, o jornal estampava em sua capa uma notícia que gerou grande comoção nacional, unindo brevemente situação e oposição: acabara de falecer Francisco Beiró, vice-presidente eleito de Yrigoyen ${ }^{172}$. Sua morte trouxe à tona o fato de que a Constituição do país não considerara a hipótese de morte de um vice-presidente eleito não empossado. O Congresso se dividiu entre os apoiadores de uma nova eleição e aqueles defensores da escolha do novo nome por parte do próprio partido, a ser oficializado somente pelo Colégio eleitoral que elegeu a fórmula presidencial.

Quanto a essa questão, o jornal não demonstrou em nenhuma de suas colunas e editoriais um posicionamento claro, apenas buscando deixar evidente a sua consternação quanto à necessidade de uma rápida resolução do fato ${ }^{173}$. No fim, foi decidido que o partido escolheria um novo nome em convenção, e o apresentaria para aprovação do parlamento, fato ocorrido em 12 de agosto, sob os protestos da oposição. O nome escolhido foi o de Enrique Martínez, aprovado por ampla maioria ${ }^{174}$.

Findadas os debates acerca da vice-presidência, novas divergências passariam a ganhar o âmbito nacional com força renovada. Trata-se de uma denúncia perpetrada pelo

\footnotetext{
${ }^{171}$ Editorial "Los deberes del Presidente". Idem, 09 junho 1928, pág. 6.

${ }^{172}$ Capa, "Ha muerto el vicepresidente electo, Dr. Francisco Beiró". Idem, 23 julho 1928.

${ }^{173}$ Editorial "El problema de la vicepresidencia". Idem, 23 julho 1928, pág. 4; Capa, "La muerte del vicepresidente electo plantea una cuestion politica que el texto de la constitucion no resuelve". Idem, 24 julho 1928; Editorial, "La muerte del Dr. Beiró plantea un caso de interpretación constitucional", 24 julho 1928, pág.?; Editorial "La vicepresidencia", 25 julho 1928, pág.?

${ }^{174}$ Capa. Idem, 13 agosto 1928.
} 
senador Diego Luis Molinari ${ }^{175}$, o qual acusava o senador eleito, embora ainda não diplomado, Carlos Lencinas de tramar um atentado contra a vida de Hipólito Yrigoyen. Lencinas recebeu essa denúncia com surpresa, e respondeu de forma enérgica por meio de uma carta endereçada ao Senado, onde acusava o seu acusador de se deixar levar pelas paixões políticas, e de buscar instaurar um caos político em Mendoza, sob o jugo do próprio presidente eleito ${ }^{176}$.

Tenha tido ou não bases fatuais a contra argumentação de Lencinas, ao acusar Molinari de preparar uma trama a mando de Yrigoyen, de modo a desmontar o lencinismo, o resultado das denúncias foi o envio de um novo pedido de intervenção federal na província de Mendoza, a fim de restaurar a ordem institucional e resguardar a ordem pública de quaisquer embates que pudessem se produzir entre personalistas e lencinistas.

Analisando a situação, o La Nación relembrou que a província se tornara um território propício a diversas intervenções federais ocorridas desde 1916 graças ao estado de violência e perseguição política instaurado pelos lencinistas, e fez questão de ressaltar que os mesmos se utilizaram das primeiras intervenções, decretadas pelo então aliado Yrigoyen, a seu favor.

Por isso, o jornal concordava que tanto o lencinismo, quanto o bloquismo de San Juan, não eram positivos para o sistema republicano e democrático, no entanto, o diário temia que uma nova intervenção federal, sob argumentos constitucionais frágeis, pudesse trazer ainda mais problemas à situação da província, ao gerar distúrbios da ordem e conflitos entre grupos políticos rivais. Além disso, o jornal se perguntou se tal intervenção não teria, como supunha ter havido nos primeiros anos de Yrigoyen no poder, uma clara intenção de enfraquecer a oposição e levar os seus aliados personalistas ao poder local, fortalecendo as bases do governo nacional ${ }^{177}$.

O posicionamento do jornal sempre fora bastante claro em relação às intervenções federais. Desde o início da era radical, em 1916, La Nación defendera que uma intervenção deveria ocorrer sobre bases constitucionais sólidas, e com objetivos traçados de forma precisa e direta, sem grandes alterações da ordem institucional da província, de

\footnotetext{
${ }^{175}$ Senador personalista eleito em 1928 por Buenos Aires. Destacou-se por ter sido um dos autores da lei de nacionalização do petróleo, de 1927, que ainda estava empacada no Congresso à época dessa denúncia, e também por ter sido, mais tarde, um dos idealizadores do projeto de criação de um Código Nacional de Trabalho. Na década de 1940, Molinari se tornou um forte aliado das políticas peronistas.

176 Capa. Idem, 31 julho 1928.

177 Editorial “La intervención en Mendoza”. Idem, 31 julho 1928, pág. 6.
} 
modo a não suscitar um poder supraconstitucional ao poder executivo federal. Porém, os anos de radicalismo demonstraram que as intervenções federais poderiam se tornar armas poderosas quando controladas por regimes que vissem nela uma fortuita possibilidade "legal" de coação das oposições políticas ao governo central. Por esse motivo, o jornal permaneceu firme em sua posição cética quanto aos numerosos decretos de intervenção expedidos pelo Executivo nacional, e observava preocupado os rumos conflitosos que poderiam ser traçados na nação caso o novo governo yrigoyenista voltasse a fazer uso dessa arma para calar a oposição.

Mergulhado em querelas políticas e institucionais, era dado início o segundo mandato presidencial de Hipólito Yrigoyen, empossado, junto com o seu gabinete, em 12 de outubro de 1928, sob os aplausos da maioria personalista do Congresso ${ }^{178}$.

\section{2 "Temas de la actualidad nacional": as grandes questões nacionais no despontar do novo governo}

O segundo governo de Hipólito Yrigoyen se iniciava mergulhado em denúncias por parte da oposição política, ainda reunida em torno da UCR Antipersonalista, relativas a ataques inconstitucionais oriundos da base de governo contra os expoentes políticos opositores. Era necessário que o novo governo reafirmasse as suas principais bandeiras políticas, de modo a reconectar o eleitor contemporâneo ao primeiro governo, iniciado 12 anos antes, em um momento político bastante diverso ao atual.

Os principais debates que rodearam os meses de campanhas eleitorais, e veementemente debatidos pelos editoriais do jornal, giraram em torno da economia nacional e dos rumos a serem seguidos nesse campo. À época, instaurava-se no cenário político argentino uma intensa querela intelectual entre os defensores do liberalismo econômico, aqui entendido como livre concorrência e baixa interferência estatal nos rumos econômicos, e aqueles propensos ao protecionismo econômico, com vistas ao desenvolvimento da indústria nacional.

Esse debate não era uma novidade argentina, posto que ele se instaurara no mundo ocidental durante a década de 1920. No entanto, na Argentina ele adquiriu cores e matizes próprias, devido ao jogo de interesses que contrapunham dois grandes grupos nacionais. O jornal abriu, ao longo da campanha, uma coluna especial em seu caderno intitulado "Temas de la actualidad nacional" para que intelectuais e economistas diversos,

\footnotetext{
${ }^{178}$ Idem, 13 outubro 1928, edição especial, pág. ?.
} 
representantes das duas visões econômicas, pudessem apresentar a sua visão acerca da questão. Em uma dessas colunas, resumia-se quais eram os dois lados do debate econômico:

\begin{abstract}
¿Conviene a los más vitales intereses argentinos del presente y al porvenir inmediato del país enfrentar resucitamente el problema de su industrialización a base de un radical protecionismo aduaneiro? (...) En la República Argentina se ha acentuado durante estos últimos años la lucha entre dos tendencias, representadas por poderosos núcleos de hombres de negocios que sustentan dos doctrinas económicas opuestas entre si. El núcleo más antiguo y que mejores posiciones tiene tomadas es el que representa a la industria agropecuaria y sustenta la doctrina económica de puertas abiertas a la manufactura extrangera, procurando la intensificación del régimen agropecuario (...) $\mathrm{El}$ segundo núcleo, es decir, la tendencia opuesta, de menor edad que anterior (...) pero fuerte y ya bastante difundida, representa la naciente industria manufacturera nacional y aspira a obtener de los Poderes Públicos un régimen económico de franco e decidido proteccionismo aduanero a las actividades que le son propias. ${ }^{179}$
\end{abstract}

As duas questões suscitavam grande discórdia no meio econômico argentino desde a Primeira guerra mundial, momento em que as exportações de carne e cereais argentinos perderam espaço no mercado internacional, abrindo espaço para o lento, porém gradual, desenvolvimento de um setor industrial, baseado em estímulos estatais iniciados com o primeiro governo radical, histórico defensor do fortalecimento da economia nacional. Aos agropecuaristas argentinos, interessava o velho sistema de trocas, onde os produtos agropecuários argentinos tinham escoamento garantido para a Inglaterra, que pagava a esses produtos a partir dos lucros gerados pela venda de itens industrializados ingleses para a Argentina. Ocorre que, a partir da grande guerra, o mercado inglês sofreu bruscas perdas de capital, alterando sensivelmente os seus acordos com os argentinos, o que levou à crise do setor agropecuário no início daquela década.

Já os novos industriais não viam com bons olhos esse sistema, uma vez que a qualidade dos produtos industriais ingleses era superior aos argentinos, e seu valor de mercado, quase sempre, inferior ao praticado pelo similar nacional, garantindo, portanto, a invencibilidade nas vendas dos produtos estrangeiros. Os industriais argentinos acreditavam que, para o seu desenvolvimento, era preciso que o Estado argentino garantisse proteção à indústria nacional frente aos avanços dos produtos estrangeiros.

\footnotetext{
${ }^{179}$ Editorial "Proteccionismo y Libre cambio". Idem, 27 abril 1928, pág.12.
} 
Como se percebe, as duas ideias são, aparentemente, irreconciliáveis, o que levou a anos de embates entre os dois blocos ao longo de todo o governo Alvear. Por essa razão, o tema retornara com força durante as campanhas eleitorais, mobilizando políticos, intelectuais, população e a imprensa a arguirem o assunto e tomarem posições. O La Nación demonstrou a sua opinião de modo não muito claro, oscilando, por vezes, entre as duas perspectivas, ou buscando, como nos parece, encontrar um meio termo entre ambos os grupos. Naquela mesma coluna, o jornal antecipava parte de suas conclusões:

(...) Situadas así las cosas en su verdadero lugar, estimamos peligroso y creemos que es marchar muy de prisa pretender convertir en el dia a la Republica Argentina por medio de un régimen aduanero abiertamente proteccionista en un país manufacturero que se baste a sí mismo (...) pues es lógico y normal proceso evolutivo de los pueblos señala que a la vida pastoril sigue el período do perfeccionamiento agropecuário y a éste la historia nos enseña, sigue el periodo de franca industrialización manufacturera. ${ }^{180}$

O jornal era um defensor da industrialização natural do país, e acreditava que essa industrialização ocorreria por meio do setor agropecuário e do desenvolvimento gradual de uma indústria voltada, primeiro, para a sua produção e escoamento, gerando assim as condições propícias ao surgimento do capital que poderia ser investido, ao longo dos anos, em outras áreas chaves da indústria argentina. Assim, seria muito arriscado para o país, em sua visão, abandonar um sistema econômico que por tantas décadas beneficiara o progresso econômico e material da nação, em nome de uma aposta em um setor que não era ainda capaz de dar certeza de desenvolvimento ao país.

Não obstante a sua recusa em aceitar um sistema protecionista industrial, o jornal em nenhum momento buscou desqualificar os esforços do setor industrial nacional, ou mesmo deixou de propor formas de ajuda por parte do Estado para a área, encarada como essencial para o progresso nacional futuro. Pelo contrário, o jornal reconhecia os duros esforços desse setor, que desde o seu despontar não contara com outro apoio que não "la iniciativa y el trabajo de un hombre valiente y decidido, que comienza como obrero en su taller, se transforma en patrón, en empresário y en gran industrial sucesivamente" 181.

A visão do esforço individual, contando com um necessário respaldo do Estado e das instituições bancárias em determinados níveis adequados ao sistema de livre-

\footnotetext{
${ }^{180}$ Idem.

${ }^{181}$ Editorial "El crédito industrial”, 28 janeiro 1928, pág.?
} 
comércio, como principal motor propulsor da máquina industrial de um país, foi veementemente defendida pelo La Nación, que via no "intervencionismo económico de las autoridades (...) las más abundantes experiencias, como también los fracasos más evidentes. $" 182$.

Ainda no mês de outubro, após a posse presidencial, o jornal apreciou uma interessante observação elogiosa por parte do novo presidente quanto a uma possível condução da economia argentina segundo o modelo suscitado pelo La Nación. Como o próprio editorial destaca:

La opinión ha sido favorablemente impresionada con el propósito que ha expresado el presidente de la República de propender al mejoramiento de la situación en que se encuentran las industrias agropecuarias por medio de la valorización de los respectivos productos. Según hemos informado, ha anunciado ese designio a los representantes de las empresas frigoríficas y de exportadores de cereales $(\ldots)^{183}$

Essa acabou se tornando uma das poucas linhas de comunicação afável entre o jornal e o governo yrigoyenista durante esse período.

Para o La Nación, o desenvolvimento econômico nacional urgia como uma pauta prioritária dentre todas as demais para o novo governo radical, priorizando-se:

La conquista de nuevos mercados para nuestras carnes, una retención mayor de provechos para los productores de cereales, la organización del crédito agrícola y la más amplia difusión del transporte y perfeccionamiento de sus servicios comportan indiscutiblemente una teoria de cuestiones de gobierno cuya solución feliz se proyectaria en un aumento formidable de nuestra potencialidad material. (...) Viemos, en suma, con un sentimiento de adhesión y de optimismo las preocupaciones del Sr. Yrigoyen en beneficio de estos temas fundamentales para el progreso nacional. ${ }^{184}$ (Grifo meu)

Apesar de um elevado contentamento com os rumos ditados por Yrigoyen ao ato de sua posse presidencial, em poucos meses, como se verá, o jornal voltou a se desiludir com muitas das pautas elaboradas pelo governo, como na questão da nacionalização do petróleo, discussão que estava em aberto havia anos, e que gerava grande consternação entre os investidores internacionais e seus parceiros argentinos. Yrigoyen começou a

\footnotetext{
182 Editorial "Tutela económica oficialista”, 23 março 1928, pág. 6.

${ }^{183}$ Editorial "El Poder Ejecutivo y la defensa de la producción”, 21 outubro 1928, pág. 8.

${ }^{184}$ Editorial "El desenvolvimiento económico", 27 outubro 1928, pág. 6.
} 
discutir a possibilidade de se nacionalizar o petróleo argentino, como aqui já analisado, ainda no seu primeiro mandato, quando criou, a poucos meses de findar seu último ano de governo, a YPF, empresa estatal do ramo petrolífero.

O debate permanecera aceso durante a presidência de Alvear, e ganhara importantes rumos a partir da ação dos deputados personalistas, que conseguiram criar e aprovar uma lei de nacionalização do petróleo em 1927. Como se verá, o referido projeto, à época do início do novo mandato presidencial de Yrigoyen, se encontrava em mãos do Senado nacional, controlado pela oposição antipersonalista e seus aliados, e não logrou êxito enquanto durou sua presidência. No entanto, o debate continuou a gerar grande ansiedade e medo entre empresas estrangeiras ${ }^{185}$.

Por fim, ainda pairava no ar a tensa campanha eleitoral que acabar de ocorrer, permeada de conflitos violentos e querelas intermináveis envolvendo personalistas e oposição, tanto no meio social, quanto no Congresso. O problema do reconhecimento dos diplomas, principalmente dos parlamentares de Mendoza e San Juan, permanecia produzindo debates acalorados e embates violentos nas províncias em questão. Para elevar ainda mais a tensão, o novo governo recentemente empossado tomou, como uma de suas primeiras atitudes, declarar a intervenção federal sobre as províncias de Mendoza e San Juan, aprovadas pelo jornal, e mais tarde, sobre Corrientes e Santa Fé, desta vez sob as críticas do veículo.

Ao tomar essa atitude, o governo utilizou o argumento da reordenação institucional e pacificação dessas províncias, convulsionadas pelos recentes eventos envolvendo suas lideranças, no entanto, o que se observou nos meses seguintes foi um aumento trágico das cenas de violência envolvendo grupos armados personalistas e opositores.

\subsection{O ano de 1929: incertezas e tormentas}

A intervenção federal sobre a província de San Juan, dominada pela facção radical bloquista, antiyregoyenista, começou de maneira trágica: durante a chegada do interventor federal e das tropas nacionais à província, ocorreu o entrechoque armado entre yrigoyenistas e bloquistas, sendo registrado mais de 200 tiros, com o saldo de dois mortos

${ }^{185}$ DI TELLA, Torcuato S. História social da Argentina contemporânea. Brasília: FUNAG, 2010, pág. 171. 
e vários feridos ${ }^{186}$. A multidão logo foi controlada e dispersada, e um estado de sítio recaiu sobre a província a fim de evitar novos embates. Após esses acontecimentos alarmantes, o interventor federal assumiu, como de praxe, a chefia provisória do poder executivo local e procedeu à reorganização dos poderes executivo e legislativo.

O La Nación, por meio de um enviado especial à província, observou à primeira mão o ocorrido, e continuou a acompanhar com grande interesse o desenrolar dos primeiros dias de intervenção. Ao o que o jornal categoricamente ilustrou como um "retorno a la barbarie", vinha à tona novos tons de cinza nos tristes espetáculos assistidos na província, já recheada de inúmeros casos de abusos de autoridade, perseguição a opositores e censura da liberdade de imprensa por parte do governo deposto: ocorre que o novo interventor e sua equipe, aparentemente, em nada estavam colaborando para a reorganização institucional e republicana da província, antes isso, pois se tornava claro que os próprios mecanismos utilizados pelo interventor passavam pela via da violência e perseguição:

Las informaciones procedentes de San Juan son alarmantes, porque demuestran que en esa província los escopos políticos han comenzado a desbordarse en términos que significan el retorno a la barbarie (...) como un hecho que debia tener en vista el interventor para adoptar las medidas que devolviesen la tranquilidad que empezaba a perderse. Poco después, las circunstancias que rodearon el cumprimiento de certas órdenes de registros domiciliarios, la autorización dada a la policia para allanar los domicilios, sin determinación alguna, según su criterio, y la clausura de las imprentas de diarios opositores, hicieron ver que el cambio de la situación gubernativa no había sido acompañado por la reforma de los procedimientos. ${ }^{187}$

As acusações de um suposto uso político das intervenções federais em San Juan e Mendoza não tornou obscura a defesa por parte do jornal da necessidade das mesmas, as quais haviam sido convocadas, segundo o próprio jornal, para levar a ordem a um território sem lei, acostumado a toda espécie de abusos por parte de seus governantes. Mas essa defesa da ordem institucional não poderia, para ser validada, fazer uso das mesmas armas utilizadas pelo regime deposto ${ }^{188}$.

Os primeiros atos positivos da intervenção de San Juan foram recebidos com certo furor pelo La Nación, ao anunciar em sua capa a prisão do ex-governador afastado da

\footnotetext{
${ }^{186}$ Capa. La Nación, 24 dezembro 1928.

${ }^{187}$ Editorial "El retorno a la barbarie". Idem, 21 janeiro 1929, pág. 4.

${ }^{188}$ Editorial “Serenidad”. Idem, 22 janeiro 1929, pág. 6.
} 
província, Aldo Cantoni, ex-socialista co-fundador do bloquismo ao lado de seu irmão recém-eleito senador nacional Federico Cantoni, e de muitos outros membros partícipes da liderança do bloquismo ${ }^{189}$. No entanto, o êxtase inicial logo sucumbiu a inúmeros casos considerados graves por parte do jornal, originados das primeiras ações adotadas pelos interventores federais em ambas províncias ${ }^{190}$.

As intervenções federais sobre Mendoza e San Juan dominaram o cenário político ao longo de todo o ano de 1929. A importância dada aos acontecimentos recaia sobre o peso que os mesmos representavam para as relações institucionais do Poder executivo federal para com as províncias, bem como para a própria estabilidade do regime recéminaugurado. Segundo o jornal, os violentos e conturbados acontecimentos que levaram a esses decretos de intervenção representam, nas palavras do mesmo, um signo dos tempos ${ }^{191}$ que se abriam naquele início de ano, e deveriam marcar, dessa forma, boa parte do contexto que dali se desenrolaria.

Ainda no início do ano de 1929, entre os meses de janeiro e março, antes que os acalorados debates políticos daquele ano tomassem conta dos editoriais diários do jornal, apresentava-se ali as preocupações econômicas que assolavam o país e que deveriam, na concepção do veículo, figurar as pautas primárias do novo governo. Esses problemas, sobretudo em meio aos acordos econômicos entre Argentina e Grã-Bretanha, os quais estavam sendo fomentados pelas diplomacias de ambas nações, no que concerne ao escoamento das carnes e dos cereais argentinos, que já observavam uma franca queda nos valores de exportação, ainda estavam pendentes de solução. ${ }^{192}$

Outra questão que preocupava o jornal dizia respeito à letargia verificada na condução da máquina pública federal. Após o início do ano, o governo radical decidiu demitir os ocupantes de diversos cargos administrativos sob o argumento de retenção de gastos públicos, no entanto, na observação do La Nación, a desocupação arbitrária desses cargos, em sua maioria essenciais à condução do Estado, tinham como motivo primordial trocar os aliados do governo anterior por funcionários ligados ao personalismo ${ }^{193}$.

$\mathrm{O}$ assunto da vez, no entanto, continuava a ser as intervenções e as querelas em torno dos diplomas dos senadores de Mendoza e San Juan, ainda pendentes de votação, o

\footnotetext{
${ }^{189}$ Capa, "Ha sido decretada la detencion del Dr. Aldo Cantoni”. Idem, 23 janeiro 1929.

${ }^{190}$ Capa, "Una ojeada sobre la actualidad de la politica cuyana”. Idem, 24 janeiro 1929.

${ }^{191}$ Editorial "Un signo de los tiempos". Idem, 25 janeiro 1929, pág. 6.

192 Editorial "Nuestro más grave problema actual”. Idem, 29 janeiro 1929, pág. 6.

193 Editorial "Falta de administración". Idem, 20 fevereiro 1929, pág. 6; Editorial "La paralización administrativa”. Idem, 16 abril 1929, pág. 6.
} 
que ocorreria com o retorno do Senado às suas atividades. Em Mendoza, a situação política não corria da forma como era esperado. Acusações de perseguição aos ramos lencinistas por parte de facções yrigoyenistas, bem como aos críticos do interventor federal, dentre eles veículos de comunicação locais e outros grupos similares, começavam a chegar às ruas de Buenos Aires e à oposição no Congresso. O próprio governador afastado, da família Lencinas, enviou uma carta ao presidente Yrigoyen acusando o interventor federal de levar o caos social e administrativo à província. As acusações foram respaldadas em parte pelo La Nación, e somente no que concernia ao despotismo praticado pelo interventor, o que já vinha sendo acusado pelo próprio jornal ${ }^{194}$.

Não bastasse o caos político que tomara forma em Mendoza e San Juan, também em Santa Fé os ares de intervenção federal começavam a ser sentidos pela oposição. Havia nesta província uma séria tensão entre os poderes executivo e legislativo locais, o que culminou com a decisão autoritária do governador de Santa Fé de mandar a polícia cercar o congresso provinciano em determinada ocasião, ainda durante o governo de Alvear, o que foi interpretado pela justiça local e nacional como um ato arbitrário e inconstitucional. A origem dessa tensão surgira do contrassenso existente entre o governo da província, controlado por personalistas, e o parlamento, sob controle opositor. No entanto, a ajuda por parte do poder federal ainda não havia sido mandada para a localidade, o que o jornal creditava à falta de adesão plena dos personalistas de Santa Fé ao personalismo nacional.

No início de fevereiro, um grupo de emissários do governo personalista de Santa Fé se reuniram a portas fechadas com o presidente Yrigoyen, o que foi encarado com estranheza, pois o script governamental pedia, conforme tradição, que essas questões fossem levadas primeiro ao Ministro do Interior, que tomaria as primeiras providências. No entanto, ocorrera o inverso, e os emissários foram recebido e ouvidos pessoalmente por Yrigoyen.

Nessa reunião, realizada sem comunicações e registros oficiais, teria sido debatido, conforme apurou o La Nación, a partir de contatos na Casa Rosada, uma possível intervenção federal em Santa Fé, a fim de coibir o legislativo e fortalecer o governo personalista local. Em troca, foi oferecido o total apoio dos políticos locais ao presidente. Yrigoyen teria respondido então aos emissários que não se preocupassem, pois Santa Fé viria a sofrer intervenção federal, a fim de controlar a situação ${ }^{195}$. No dia

\footnotetext{
${ }^{194}$ Editorial “La situación de Mendoza”. Idem, 03 fevereiro 1929, pág. 6.

195 Capa, “Tengan por seguro que irá a Santa Fe la intervención”. Idem, 05 fevereiro 1929.
} 
seguinte a esse encontro, o jornal estampara em sua capa e editorial a frase do presidente, e encarou como muito preocupante que decisões tão complexas pudessem ser tomadas unilateralmente pela presidência em encontros casuais e não oficiais ${ }^{196}$.

A intervenção federal sobre Santa Fé foi oficialmente decretada pela Presidência da república em abril de 1929, sendo que sua apreciação ainda seria levada a cabo pelo Senado nacional, o qual ainda se encontrava em recesso legislativo. O jornal considerou todo o episódio relativo ao surgimento dessa nova intervenção como uma comédia sem graça, devido ao alto grau de unilateralidade da ação, baseada exclusivamente na boa vontade de Yrigoyen para com seus próceres santafecinos.

(...) la situación de Santa Fe era obscura porque todo dependia exclusivamente de los buenos o malos ojos con que el presidente de la República resolviera mirar (...) el gobernador de Santa Fe se encuentra ahora sano y salvo. Ha conquistado el apoyo ferviente de quienes lo repudiaban con altivez $(. . .)^{197}$

A intervenção sobre Santa Fé, além de proceder de uma ação benevolente por parte do próprio Presidente da República, ainda carecia, segundo o jornal, de argumentos sólidos e das mais essenciais prerrogativas constitucionais, como no caso das outras províncias já sob intervenção ${ }^{198}$. Aliás, a situação de Mendoza e San Juan continuava a ganhar destaque nas páginas do La Nación. Em 03 de fevereiro, o jornal afirmava que "en Mendoza amenaza tener desenvolvimientos inesperados la incidencia planteada por un magistrado que, al declinar su cargo, denuncia la ingerencia del secretario de Gobierno de la intevención en el trámite (...)" ${ }^{\prime 99}$. O magistrado em questão fora afastado quando da dissolução do poder judicial da província, e suas acusações fomentavam ainda mais as denúncias contra os interventores federais e suas ações possivelmente orientadas por interesses partidários.

Em abril daquele ano, o Congresso argentino começava a se preparar para abrir um novo período parlamentar. No Senado, a oposição antipersonalista pressionava a situação a iniciar a nova sessão com as votações dos diplomas dos senadores Lencinas e Cantoni, o que fora rechaçado pelos personalistas, que passaram a boicotar as sessões destinadas às discussões no parlamento ${ }^{200}$. A situação era encarada com perplexidade,

\footnotetext{
${ }^{196}$ Editorial "La situación de Santa Fe". Idem, 06 fevereiro 1929, pág. 6.

${ }^{197}$ Editorial "La comedia santafecina”. Idem, 20 abril 1929, pág. 6.

198 Editorial "La reorganización judicial en Santa Fé". Idem, 21 abril 1929, pág. 6; Capa, "En Santa Fe causa alarma el alcance de la intervención”. Idem, 22 abril 1929.

${ }^{199}$ Editorial "Del cuadro cuyano". Idem, 23 fevereiro 1929, pág. 6.

200 Capa, "De los Senadores ausentes no se han recibido noticias". Idem, 28 abril 1929; Capa, "Tampoco ayer el Senado obtuvo el quorum necesario". Idem, 04 maio 1929.
} 
pois o La Nación creditava o boicote personalista como mais uma artimanha autoritária por parte do executivo nacional:

Un miembro del sector personalista afirmó en el recinto del Senado que los legisladores de su partido aceptaban la responsabilidad de la obstrucción. (...) En suma, los legisladores vinculados a la Presidencia conspiran con su resolución contra las facultades y el prestigio del Congreso (...) Trátase, por lo tanto, de un programa essencialmente revolucionário, que tiende a eliminar en la actividad política de la República el papel de las cámaras y concentrar en la acción del Gobierno la totalidad del poder. ${ }^{201}$

De fato, a irresoluta atitude de boicote e falta de diálogo por parte da situação personalista para com a oposição, em ambas as Casas parlamentares, postergou por longa data o trâmite de projetos vitais para a nação, como a aprovação dos decretos de intervenção federal expedidos pela Presidência da República durante o recesso legislativo, a discussão dos gastos públicos, que aumentara em grande medida no período 1927-29, do orçamento, que teria déficit para o ano vigente, bem como para a resolução imediata do impasse dos diplomas dos senadores e para o encaminhamento das demais pautas legislativas.

O mais impactante a médio prazo, segundo a observação do jornal em numerosos editoriais dedicados ao tema, seria a paralização das atividades legislativas devido a intransigência do governo e de seus aliados no Congresso. Em uma Argentina enfraquecida por uma crise interna ainda em expansão, uma paralisia como essa apenas aprofundaria ainda mais o caos político, administrativo e econômico do país. Outrossim, a falta de um legislativo nacional vigilante poderia impactar em uma força desmedida concentrada na Presidência, que poderia concentrar todas as atividades políticoadministrativas, enfraquecendo o sistema republicano de tripartição dos poderes ${ }^{202}$.

Enquanto os impasses com as intervenções federais à Mendoza e San Juan pareciam começar a tomar o rumo à normalidade institucional ${ }^{203}$, os debates acerca dos diplomas no Senado começavam a tomar forma. O primeiro dos senadores a ter o seu diploma analisado pela casa foi Federico Cantoni, o líder bloquista de San Juan. Entre 19 e 25 de julho, Cantoni proferiu a sua defesa discursando no plenário do Senado,

\footnotetext{
${ }^{201}$ Editorial "Por mal camino". Idem, 04 maio 1929, pág. 6.

${ }^{202}$ Editorial "La pasividad parlamentaria". Idem, 09 agosto 1929, pág. 6; Editorial "No hay congreso". Idem, 18 agosto 1929, pág. 8; Editorial "Una transgresión fundamental". Idem, 20 agosto 1929, pág. 6; Editorial "La realidad del sistema democrático". Idem, 21 agosto 1929, pág. 6; Editorial "Minorias sin función". Idem, 24 agosto 1929, pág. 6; Editorial "Deberes olvidados". Idem, 02 setembro 1929, pág. 4; Editorial "La difamación parlamentaria". Idem, 06 setembro 1929, pág. 8.

${ }^{203}$ Editorial "Hacia la solución". Idem, 16 julho 1929, pág. 6.
} 
argumentando que o impedimento apresentado ao seu diploma decorria não de problemas eleitorais na sua província, mas sim de uma franca perseguição liderada pelos setores yrigoyenistas a ele e seus aliados ${ }^{204}$. Acostumado a discursar para grandes massas populares, Cantoni arrancou risadas dos senadores presentes, ao utilizar termos jocosos para se referir a políticos, incluso o presidente Yrigoyen, a quem chamava de "el viejo". 205

Apesar do humor de sua fala, e do tom agressivo apresentado contra o governo federal, Federico Cantoni teve o seu diploma recusado pelo Senado, por quatorze votos a seis. A notícia foi bem recebida pelo La Nación, que afirmou:

Desde que se inició la controversia fijamos nuestra línea de conducta. Adversarios de la ilegalidad, cualquiera que sea su procedencia, expresamos nuestro juicio en contra de los diplomas (...) la propaganda de La Nación ha sido inalterable. Por esta razón hemos combatido el régimen gubernativo de San Juan que motivó la ley del Congreso, y hemos censurado asimismo sistema de violencias, digno del anterior, con que dió principio la misión federal. El Senado ha cumplido ahora con su deber. ${ }^{206}$

Ainda restara votar os diplomas de Mendoza, no entanto, apenas em setembro a base governista aceitou dar início às discussões acerca desses diplomas. Enquanto isso, uma vez rechaçado pelo Senado, Federico Cantoni havia decidido retornar para San Juan, o que foi recebido com alarme pelo governo, devida a já conturbada situação política vivida na província, ainda sob intervenção federal.

Passada a votação dos diplomas de San Juan, o Senado pôde se voltar para a votação do projeto de intervenção à província de Corrientes. A Comissão de Negócios Constitucionais do Senado foi a primeira a se pronunciar sobre o projeto e a aconselhar o seu rechaço ${ }^{207}$, o que ia de encontro com a opinião geral do jornal, também contrário a esse novo pedido de intervenção enviado pela Presidência. O jornal já vinha questionando, dias antes, o motivo pelo qual o presidente da República ainda não se pronunciara sobre a reorganização dos poderes nas províncias sob intervenção, e o motivo pelo qual o Congresso ainda não havia votado os decretos de intervenção em Corrientes e Santa $\mathrm{Fe}^{208}$.

\footnotetext{
${ }^{204}$ Capa, "El jefe del bloquismo sanjuanino comenzó a hacer su defensa". Idem, 19 julho 1929.

205 Idem.

${ }^{206}$ Editorial "El rechazo de los diplomas". Idem, 03 agosto 1929, pág. 6.

${ }^{207}$ Editorial "El proyecto de intervención en Corrientes". Idem, 04 agosto 1929, pág. 6.

${ }^{208}$ Editorial "Soluciones pedientes". Idem, 27 julho 1929, pág. 6.
} 
O questionamento acerca da parca atuação apresentada pelo presidente Yrigoyen desde o início do seu governo, prestes a completar o primeiro ano de existência, frente às grandes questões nacionais permeava diversos editoriais inflamados do jornal. Em um destes, o La Nación se indagava se o presidente se esquecera por completo de suas obrigações constitucionais e do seu dever como líder da nação de reerguê-la das turbulentas águas que vinham se infiltrando nas fissuras de seu edifício ${ }^{209}$.

A dívida pública atingira uma soma tão elevada em meados daquele ano, segundo estimativa não oficial apresentada pelo jornal no começo do segundo semestre ${ }^{210}$, que as empresas e indústrias prestadoras de serviços para o governo estavam sem receber a meses, o que provinha da falta da firma presidencial, isto é, de despacho presidencial autorizando o pagamento dessas prestadoras ${ }^{211}$.

Não apenas os prestadores de serviços nacionais estavam sem receber, como também as empresas britânicas contratadas para construir navios destinados à Marinha argentina estavam sem receber os valores referentes ao contrato firmado, o que comprometia, como bem observava o La Nación, a situação da diplomacia argentina no mercado internacional ${ }^{212}$. Apesar do problema do pagamento dos navios, a diplomacia argentina, e o governo, conseguiram angariar a sua primeira vitória no campo econômico com o acordo, firmado com a Grã-Bretanha, do crédito recíproco anglo-argentino, que retomaria o sistema de trocas que coexistira entre os dois países até a Primeira guerra mundial $^{213}$. No entanto, essa vitória ainda não servira para tirar o governo de sua inércia administrativa.

Em meio a letargia do Poder executivo federal, o Senado continuava a exercer as suas funções de poder vigilante, dessa vez, relativo ao decreto presidencial que impunha a intervenção federal sobre a província de Corrientes. O projeto, que estava parado no Senado desde o retorno das atividades legislativas, voltara a ser discutido pela casa, que decidiu, para fins de reconhecimento das causas que levaram à execução dessa intervenção, convocar o Ministro do Interior ao recinto. Porém, a negativa por parte do ministro de atender à solicitação do Senado, sob o argumento de que a Constituição não

\footnotetext{
${ }^{209}$ Editorial "Mando discrecional”. Idem, 31 julho 1929, pág. 6.

${ }^{210}$ Editorial "La deuda pública argentina". Idem, 28 julho 1929, pág. 6.

${ }^{211}$ Editorial "Las deudas del Gobierno". Idem, 18 julho 1929, pág. 6.

212 Editorial "Una actitud que compromete al país". Idem, 31 julho 1929, pág. 8; Editorial "La absorción presidencial". Idem, 19 julho 1929, pág. 6.

${ }^{213}$ Editorial "El crédito recíproco anglo-argentino". Idem, 11 setembro 1929, pág. 8.
} 
reconhecia ao legislativo a capacidade de superitendência sobre nenhum dos poderes existentes na República, causou grande furor e contenda entre governistas e opositores.

A atitude, amplamente criticada pelos principais constitucionalistas argentinos nos dias seguintes, foi considerada, pelo La Nación, um aceno do governo rumo à ditadura do executivo ${ }^{214}$. A negativa por parte do governo também foi condenada pela Suprema Corte da Argentina, a partir de ação perpetrada pela oposição, que reconheceu que a Constituição argentina reconhecia ao Poder Legislativo a faculdade de fiscalizar as atividades do Poder Executivo ${ }^{215}$.

À parte dessa contenda, em setembro de 1929, o Senado deu início à votação do diploma de Carlos W. Lencinas, senador eleito por Mendoza. A situação de Lencinas transcorreu de modo similar ao de Cantoni: sua defesa se baseou na falta de provas de que tenha ocorrido fraudes eleitorais durante as eleições na província de Mendoza e também acusou o Poder executivo federal de tentar retirá-lo do poder à força. No entanto, a defesa de Lencinas não lhe bastou, e seu diploma também foi rechaçado pelo Senado.

Lencinas, porém, perdera o Senado para ganhar a imortalidade na história argentina, de modo trágico, todavia. Após ter o seu diploma recusado pelo parlamento, Lencinas, não sem antes dirigir uma carta ao presidente Yrigoyen acusando-o de perseguição, retornou à Mendoza para se reunir com seus seguidores. Chegou à estação de trem às 16:45 da tarde, onde cerca de cinco mil pessoas, sem vigilância de policiais, o aguardavam para saudá-lo e acompanhá-lo rumo ao Círculo de Armas, local onde proferiria o seu discurso de retorno. Já no Círculo, enquanto se preparava para iniciar o seu discurso, tiros foram disparados em sua direção, e Lencinas morreu com um tiro no peito $^{216}$.

O assassinato de Lencinas foi veementemente rechaçado e criticado por todos os partidos nacionais, e foi categorizado pelo La Nación como um ato de barbárie absoluta, e o considerou, por meio de um enérgico editorial, uma consequência direta dos atos funestos praticados pelos interventores federais ${ }^{217}$ em Mendoza e pela perseguição política praticada pelo governo federal:

El jefe del radicalismo lencinista de Mendoza ha caido asesinado ayer mientras asistia a una manifestación de sus correligionarios.

\footnotetext{
${ }^{214}$ Editorial "Asenos de dictadura”. Idem, 07 setembro 1929, pág. 6.

${ }^{215}$ Editorial "El fundamento de la fiscalización legislativa". Idem, 09 setembro 1929, pág. 6.

${ }^{216}$ Capa, "Ayer por la tarde, de llegada a Mendoza, fue muerto de un balazo el Dr. Carlos W. Lencinas". Idem, 11 novembro 1929.

${ }^{217}$ Editorial "Los sucesos de Mendoza”. Idem, 12 novembro 1929, pág. 6.
} 
Veinticuatro horas antes habia dirigido al presidente de la República un despacho en el que le denunciaba el plan de producir actos de violencia, llegando a cualquier extremo para impedir que se pusiera al frente de las fuerzas que le respondian. " $V$. E. debe adoptar en tal caso - decia el Sr. Lencinas - las medidas que corresponden para prevenir cualquier exceso, si es que no quiere asumir ante el país la responsabilidad de los sucesos que pueden produrcirse en Mendoza a mi llegada, en el caso de que se atente contra mi persona o en el de que los agentes de V. E. pretendan impedirle por la fuerza a mi partido el libre ejercicio de sus derechos" (...) Las responsabilidades directas se deslindarán oportunamente, o no se deslindarán. Pero desde ahora puede afirmarse que nos hallamos frente a las consecuencias extremas de la politica de persecución y de odio llevada a las províncias por las intervenciones federales. En nombre de um presunto "plebiscito", que no fué sino la exteriorización normal de la voluntad de la mayoría (...) se quiere imponer que se dobleguen las provincias en las mantienen fuertes las tendencias contrarias al gobierno nacional. ${ }^{218}$

A morte de Lencinas foi tributada a José Cárceres, um homem comum pertencente ao personalismo yrigoyenista. Cárceres não viveu para contar a sua versão da história, pois foi morto durante perseguição policial. Sua esposa, que reconhecia sua militância radical, não acreditara que ele tivesse sido o assassino de Lencinas, pois afirmara que a arma responsável pela morte deste não pertencia ao seu marido ${ }^{219}$. Ela viveu para defender que Cárceres foi vítima de um complô arquitetado pelas lideranças personalistas e pelo Klan radical, que foi uma espécie de grupo popular paramilitar ligado aos setores personalistas do radicalismo.

No dia seguinte à morte de Lencinas, veio ao conhecimento do La Nación a existência de dois telegramas despachados pelo Ministro do Interior ao comissário interino de polícia de Mendoza, ordenando que não se procedesse a prisão de Lencinas, evitando a proximidade de policiais locais dos grupos que fossem recebê-lo em sua chegada. A ordem foi reiterada após questionamento por parte do comissário, sob a ameaça de perda do cargo caso este não obedecesse às ordens ${ }^{220}$. A troca de telegramas entre um alto membro do governo federal e o responsável pela polícia daquela província, sob teor de ameaça por parte do primeiro, à poucas horas da chegada de Lencinas à Mendoza, foi encarada pelos principais jornais de oposição como uma possível prova do envolvimento do governo, ou do partido governante, no assassinato.

\footnotetext{
${ }^{218}$ Editorial "En plena barbarie”. Idem, 11 novembro 1929, pág. 4.

${ }^{219}$ Capa. Idem, 12 novembro 1929.

${ }^{220}$ Editorial "No proceda antes de recibir ordenes de este ministerio: aludia así el ministro del Interior a la recomendación de no detener al viajero". Idem, 12 novembro 1929, pág. 7.
} 
O La Nación vociferou firmemente pela condução das investigações por parte do próprio Congresso, de modo a se encontrar os reais culpados pelo crime, e sua relação com o governo ${ }^{221}$. Ainda que este não tivesse tido conhecimento prévio do assassinato, e assim queria crer o jornal, no mínimo, o governo teria culpa indireta no crime, por conta do clima de tensão surgido em Mendoza por conta da intervenção federal ${ }^{222}$.

Os dias seguintes ao enterro de Lencinas foram marcados pela revolta dos lencinistas e por acusações surgidas de diferentes meios opositores em relação ao presidente Yrigoyen ${ }^{223}$. A Liga Patriótica Argentina, que se acostumara a promover reuniões públicas de seus seguidores ${ }^{224}$, e a conclamá-los à luta contra o que chamava de despotismo radical, foi novamente às ruas, junto com outros opositores, incluso socialistas, para exigir soluções por parte do governo frente ao estado de caos que tomara conta do país em poucos meses ${ }^{225}$. Assim colocava, dentre outras coisas, o manifesto criado pela Liga Patriótica e subscrito por outros partidos:

La dignidad de la Republica com sido de nuevo ultrajada por la delicuencia política. Como com otras ocasiones, la premeditación del crimen cometido contra Lencinas fué denunciada a la autoridad, inutilmente. La repetición de atentados contra los opositores del Gobierno com todas las localidades donde el partido oficialista aparece vencido evidencia que el ataque personal es com consigna y la delicuencia política com sistema para intimidar al adversário. (...) Com presencia del estado anormal del gobierno de la Nación, cada ciudadano debe cumplir com el deber que impone "in conciencia". 226

O governo, de modo a amenizar os efeitos do ocorrido sobre sua já combalida popularidade, decidiu enviar o Ministro da Justiça à Mendoza com amplos poderes. $\mathrm{O}$ objetivo seria impedir que o Congresso apurasse a investigação, transmitindo essa função ao juiz federal de Mendoza, enquanto os parlamentares da situação deveriam impedir os debates do tema no plenário ${ }^{227}$. Essa atitude foi veementemente recusada pela minoria opositora na Câmara e, principalmente, pela maioria no Senado. O La Nación também concorreu às denúncias de uma nova ação "beligerante" do executivo federal em relação ao Parlamento ${ }^{228}$.

\footnotetext{
${ }^{221}$ Editorial "El deber del Congreso". Idem, 14 novembro 1929, pág. 10; Editorial "La situación politica y el Congreso". Idem, 16 novembro 1929, pág. 8.

${ }^{222}$ Capa. Idem, 16 novembro 1929.

${ }^{223}$ Idem, 15 novembro 1929, pág.?.

${ }^{224}$ Capa. Idem, 26 outubro 1929; Editorial "El retorno a la normalidad". Idem, 27 outubro 1929, pág. 6.

${ }^{225}$ Editorial "La Liga Patriótica dió un manifiesto". Idem, 12 novembro 1929, pág. 7

${ }^{226} \mathrm{Idem}$

227 Capa. Idem, 15 novembro 1929; Capa. Idem, 23 novembro 1929, capa; Editorial "El cuadro institucional”. Idem, 26 novembro 1929, pág. 10.

${ }^{228}$ Capa. Idem, 16 novembro 1929.
} 
Em meio às trocas de farpas envolvendo o Executivo e o Legislativo nacionais, ocorreu mais um fato agravante à tensa relação entre os dois poderes. No sistema político de então, o Presidente nato do Senado era o Vice-presidente da República, portanto, cabia a ele conduzir, sempre que necessário, debates de grande importância naquela casa. No fim do mês de novembro, com o seu apoio, a intervenção federal à Corrientes foi permitida, ainda que o Senado tenha negado a aprovação da lei de intervenção, fazendo com que tal ato fosse encarado como uma subversão da independência da casa ${ }^{229}$.

O Parlamento, a poucos dias de ver encerrado a sessão daquele ano, viu-se envolto em uma aura de conflitos e retaliações entre personalistas e oposição. Direto de Paris, o ex-presidente da República Marcelo T. de Alvear, em posição neutra desde as campanhas eleitorais do ano anterior, falou, por meio do enviado especial do La Nación na França, sobre a sensível situação política do país, logrando acusações ao presidente Yrigoyen e ao seu gabinete:

\begin{abstract}
“(...) - Las noticias cada vez más graves que me llegan de Buenos Aires me obligan a salir del silencio que me había impuesto. (...) los hechos hablan con mayor elocuencia cada dia, demonstrando que la honda pertubación moral y política que padece el país es obra de Yrigoyen y de la ausencia completa de gobierno. ${ }^{230}$
\end{abstract}

O ano de 1929, ao que se veria, não havia de terminar com algum auspício ao presidente. Em 24 de dezembro, enquanto saia escoltado de sua casa na rua Brasil 1039 rumo à Casa Rosada, Yrigoyen foi vítima de um atentado contra sua vida, perpetrado por um anarquista chamado Gualterio Marinelli, que disparou três tiros rumo ao carro em que estava o presidente, sem que conseguisse acertá-lo, imediatamente a guarda presidencial disparou em defesa e matou a Marinelli.

A tentativa de assassinato de Yrigoyen foi criticada por todos os partidos, instituições e órgãos de imprensa do país, e novamente considerado pelo La Nación como um ato de pura barbaridade e incivilidade. Os comitês radicais tomaram as ruas nos dias seguintes ao atentado e marcharam em apoio a Yrigoyen. Tanto entre os comitês quanto entre os setores personalistas majoritários na Câmara dos Deputados, ganhou força a acusação aos veículos de imprensa de Buenos Aires pelo atentado, por suas duras, e diárias, críticas a Yrigoyen.

\footnotetext{
${ }^{229}$ Capa. Idem, 30 novembro 1929; Capa. Idem, 01 dezembro 1929; Editorial "La actitud del Senado". Idem, 01 dezembro 1929, pág. 10; Capa. Idem, 03 dezembro 1929.

${ }^{230}$ Capa. Idem, 16 dezembro 1929.
} 
A acusação chegou às portas do La Nación, que respondeu de forma contundente em seu editorial publicado no dia 28 de dezembro:

El atentado contra el presidente de la República ha merecido a toda la prensa y a todos los ciudadanos el mismo juicio condenatorio. Era lo que tenia que suceder, puesto que vivimos en un país civilizado. (...) El crimen politico ha merecido siempre nuestro repudio categórico, lo mismo en el caso de gobernantes como el de San Juan que en el de caudillos opositores como el que cayó hace poco en Mendoza, bajo el imperio de una intervención desorbitada. (...) Esta única circunstancia nos induce a vencer un explicabe escrúpulo jerárquico para recoger la afirmación repetida de que a los grandes diarios de Buenos Aires corresponde la responsabilidad del atentado contra el Presidente. La inculpación es ridícula y no ha sido formulada con sinceridad, ni siquiera por ofuscación. Pero el oficialismo aspira a sacar provecho del reciente episodio policial y ha concebido el plan, más ingenuo que desatinado, de coaccionar a la prensa independiente atribuyendo a su propaganda efectos que llegarían hasta el crimen. (...) La Nación no ha de sentirse coartada por ninguna amenaza. Continuará cumpliendo su misión em defensa de las instituciones y del progreso politico argentino. (...) Si el gobierno de la República desea merecer outro concepto, está en sus manos conseguirlo. 231

O atentado à vida do presidente Yrigoyen, e suas repercussões nas ruas e entre os bastidores políticos, encerrou com tons drásticos um ano de tensas relações entre os poderes Executivo e Legislativo nacionais. Mais ainda, esse triste desfecho de ano abriu a amargas pinceladas um ano que viria a ser repercutido como um dos mais trágicos da história política argentina.

\subsection{0: a derrocada da era radical}

A historiografia política sobre Argentina possuia uma heterogeneidade quanto à gama de interpretações possíveis acerca dos fatos históricos ali observáveis. No entanto, alguns pontos da oblíqua história deste país merecem observâncias similares, dada a sua importância magna para o desenrolar daquela nação. Um destes pontos de franca homogeneidade historiográfica diz respeito ao ano de 1930 e a sua importância para o desenrolar de toda a história política argentina desde então. Há quem diga que o ano de 1930 tenha se iniciado somente no mês de setembro, com a intervenção militar vitoriosa. Tal interpretação, ainda que passível de outras interpretações dissonantes, busca aferir que o tempo cronológico talvez não seja o mais capaz de abarcar a complexidade desse

\footnotetext{
${ }^{231}$ Editorial “Después del atentado”. Idem, 28 dezembro 1929, pág. 8.
} 
contexto, que se iniciou com o "plebiscito" de outubro de 1928, e chegou ao fim com a marcha de José Felix Uriburu rumo à Casa Rosada em 8 de setembro de 1930, uma marcha que marcou o início de uma nova era nesse país. No entanto, continuemos, para efeitos de elucidação desse tempo histórico sob a visão do La Nación, à $1^{\circ}$ de janeiro de 1930, cronologicamente o primeiro dia dos últimos sete meses de governo radical.

A Argentina encontrava-se em um turbilhão de conflitos políticos tortuosos. No dia 24 de dezembro do ano findado, o presidente da República, Hipólito Yrigoyen, foi vítima de uma tentativa de assassinato por obra de um militante anarquista insatisfeito com o seu governo e com a crise financeira que despontava no horizonte, onde operários e trabalhadores comuns, grupo do qual surgira o militante, foram os primeiros afetados. Ainda em recuperação do susto pelo qual havia passado, o idoso presidente Yrigoyen, contando então com 77 anos de idade, precisou lidar com três questões salutares que dividiram o país nos primeiros meses desse ano: o fim da Caixa de Conversão, a tensão política nas províncias sob intervenção e as novas eleições parlamentares.

A Caixa de Conversão, que havia sido readotada em $1927^{232}$, coexistira com a maior parte do período de apogeu econômico argentino ao longo de sua história. Esse modelo se baseia na adoção do padrão ouro por uma nação, e exige da mesma uma série de medidas econômicas internas de austeridade, bem como uma relação com potências capazes de capitalizá-lo, papel exercido pela Inglaterra por anos a fio. O ano de 1929, com a desvalorização do peso e o início de uma crise econômica internacional em franca marcha na Argentina, foi decisivo para a polêmica decisão tomada pelo governo radical, de fechamento da Caixa de Conversão e a adoção de um sistema econômico mais volátil aos novos tempos e à nova potência econômica que angariava espaço em meio aos negócios argentinos, os Estados Unidos da América.

O fim da Caixa de Conversão contrariou as elites agroexportadoras argentinas ${ }^{233}$, e também La Nación, persistente defensor dos interesses do setor agrário. O jornal creditou o fim do sistema à "impotencia para dominar la situación monetaria creada por la exportación de oro. "234 do governo federal. O diário observava com bons olhos o sistema de conversão por conta de sua maior garantia de manutenção da economia nacional sob o regime da regularidade. Com ele, o país apenas poderia emitir papel moeda segundo o depósito de uma igual quantia de ouro na Caixa, o que garantiria a certeza de

\footnotetext{
${ }^{232}$ RAPOPORT, Idem, pág. 152.

${ }^{233}$ Idem, pág. 154.

${ }^{234}$ Editorial "El Cierre de la Caja de Conversion". Idem, 03 janeiro 1930, pág. 6.
} 
que um mal governante não iria imprimir mais papéis-moedas do que a economia local pudesse realmente sustentar, evitando assim um surto inflacionário, o qual era mais frequente em regimes que não adotassem o lastro-ouro.

O Partido Socialista também foi contrário ao fim da Caixa de Conversão, o que demonstrou por meio de protestos salutares ${ }^{235}$. O fim da Caixa também colaborou para dificultar a manutenção da luta pelos privilégios agroexportadores da Argentina junto ao Império Britânico, embate que vinha sendo duramente enfrentado pela diplomacia argentina a meses, e sem grandes resultados. No lugar da Argentina, no entanto, muitos bancos norte-americanos passaram a observar o novo sistema econômico argentino com maior interesse e atenção.

Aliado ao fim da Caixa de Conversão, encontrava-se como uma preocupação central das análises do La Nación o fato de que o país ainda não possuía uma lei de gastos públicos aprovada para o ano de 1930, o que deveria ter ocorrido no fim do ano anterior. O jornal defendeu que nenhuma preocupação deveria estar acima do bom manejo da Fazenda pública, e que a preocupação primeira do governo federal para o novo ano deveria ser a implementação de uma lei de gastos e recursos ${ }^{236}$. No entanto, o diário acreditava que preocupações tão elementares não tinham lugar na mente do presidente Yrigoyen, "ajeno a todo pensamiento que no sea el de la politica electoral"237.

A terceira grande questão nacional a inaugurar o ano de 1930 seria o preparo para o novo pleito eleitoral, que colocaria à prova de fogo a União Cívica Radical em todo o território nacional. Os cômputos de algumas províncias, dentre elas a de Buenos Aires, já acusava uma provável derrota radical em grande parte do país, em decorrência de uma crescente insatisfação popular em relação ao partido governante ${ }^{238}$.

Devido à situação de desprestígio eleitoral da UCR e da possível derrota nas urnas, o que seria fulminante para o governo, que poderia perder a maioria na Câmara dos deputados e o domínio da situação nas províncias, o governo federal buscou utilizar dos instrumentos ao seu alcance para limitar o tamanho de sua derrota. A ação do Poder Executivo federal se daria nas províncias de San Juan, Mendoza e Corrientes, que ainda se encontravam sob intervenção federal, e onde o governo pretendia postergar as eleições.

\footnotetext{
${ }^{235}$ Editorial. Idem, 29 dezembro 1929, pág. 10.

${ }^{236}$ Editorial “Sin presupuesto". Idem, 03 janeiro 1930, pág. 6.

${ }^{237}$ Idem.

${ }^{238}$ Editorial "Veredicto popular". Idem, 09 janeiro 1930, pág. 6.
} 
O argumento do governo, suscitado, segundo o La Nación, a partir dos anseios de setores personalistas dessas províncias, seria relativo à situação excepcional dessas localidades, ainda mergulhadas em tensão partidária e sob forte possibilidade de fraudes eleitorais. No entanto, conforme defendido a longo tempo pelo jornal, essas províncias já estariam plenamente capazes de ver normalizada a sua situação governamental, pois o clima de tensão era fortalecido somente pela manutenção da intervenção federal. O La Nación, acusava, portanto, o governo federal de tentar dar tempo para o revigoramento do personalismo aliado nessas províncias, a fim de se garantir a vitória eleitoral da $\mathrm{UCR}^{239}$.

Em 21 de janeiro, o jornal estampava em sua capa um novo atentado político, dessa vez dirigido contra dirigentes do radicalismo bloquista na província de San Juan, nas proximidades de Jachal, em que um carro contendo membros do radicalismo yrigoyenista teriam atocaiado o carro em que vinham os líderes bloquistas, dentre eles o deputado nacional Videla Rojas, e disparado vários tiros contra este veículo, ferindo vários dos passageiros, como o próprio deputado Rojas ${ }^{240}$. O atentado gerou rápidas reações por parte dos políticos bloquistas, tanto em San Juan quanto no Congresso nacional, suscitadas principalmente por seu líder, Federico Cantoni, que entrou em contato pessoalmente com o presidente Yrigoyen para fazer as suas reclamações.

Enquanto a situação em torno do ataque contra os bloquistas transcorria, no Senado nacional, o personalismo voltava a lançar acusações contrárias à imprensa portenha, relativas ao atentado contra a vida do presidente Yrigoyen. Os ataques à imprensa voltaram a sofrer duríssimas críticas por parte do La Nación, que culpou o governo federal de buscar o cerceamento da imprensa livre, subordinando-a aos interesses do partido governante ${ }^{241}$.

No início de fevereiro, durante uma convenção do Partido Conservador na região de Lincoln, localizada em La Plata, houve um novo ataque de facções personalistas contra políticos conservadores, que debatiam o pleito eleitoral a ser realizado. O jornal voltou a lançar um ataque contra o personalismo radical, acusando-o de recorrer, não pela primeira vez, a táticas terroristas, com o fim de submeter a oposição política, sobretudo em um momento de franca retração popular do radicalismo personalista ${ }^{242}$. À reação dirigida

\footnotetext{
${ }^{239}$ Capa. Idem, 05 janeiro 1930.

${ }^{240}$ Capa. Idem, 21 janeiro 1930.

${ }^{241}$ Editorial "Voces sin ecos". Idem, 23 janeiro 1930, pág. 8.

${ }^{242}$ Editorial "El atentado de Lincoln". Idem, 03 fevereiro 1930, pág. 8; Capa. Idem, 14 fevereiro 1930; Editorial "Um estallido de barbarie". Idem, 15 fevereiro 1930, pág. 8.
} 
pelos conservadores, uniram-se os socialistas independentes e os democratas progressistas, que lançaram notas acusatórias dirigidas ao presidente da República, defendendo que a sua atuação e de seu partido estava francamente direcionada ao combate violento das forças opositoras ao governo ${ }^{243}$.

A situação política argentina passara a angariar uma maior atenção por parte de outras nações, tanto por argentinos radicados na Europa, consternados com o clima beligerante partidária do país, quanto por representantes diplomáticos e entes econômicos, preocupados com os efeitos da instabilidade política sobre a economia nacional. Conforme publicado pelo La Nación em várias de suas edições, em um campo específico para os seus correspondentes internacionais, a imprensa estrangeira, como é o caso da Revue de l'Amerique Latine da França, analisavam que as causas da crise eram tanto internas, crescimento da oposição e paralisia do governo, quanto externas, com a crise econômica crescente e a insatisfação de empresas estrangeiras com os rumos político locais. $^{244}$

Em termos de política interna, o governo radical via empacado no Senado a lei de nacionalização do Petróleo, sob forte crítica da oposição ${ }^{245}$, que não aceitava trazer a questão à tona por três questões principais: primeiro, por conta da intransigência do governo em dialogar com a oposição desde o início do mandato de Yrigoyen, que passou a articular com a base personalista uma série de boicotes às discussões opositoras, em segundo lugar por conta das intervenções federais, observadas pela oposição como uma forma do governo garantir a vitória de seus candidatos ao Senado nacional, e por fim, por considerar que haviam outras questões mais importantes no horizonte, e também por considerarem que o governo jamais apresentou pontos que edificassem a sua proposta.

Na mesma medida, o governo radical começava a encontrar sérios obstáculos na corrida pela unificação dos diferentes ramos personalistas nas províncias do interior, o que compunha uma de suas principais medidas na luta contra os avanços da oposição. Em Santa Fe, Santiago del Estero e Córdoba, os conflitos entre os diferentes ramos do personalismo dificultavam a unificação ${ }^{246}$.

$\mathrm{Na}$ medida em que se aproximavam as eleições, o personalismo passava a se utilizar de novas ferramentas na busca por eleitorado. O La Nación denunciou que o

\footnotetext{
${ }^{243}$ Editorial. Idem, 15 fevereiro 1930, pág. 10.

${ }^{244}$ Capa, "Es comentada en Paris la situación politica argentina". Idem, 05 fevereiro 1930.

${ }^{245}$ Capa. Idem, 22 janeiro 1930.

${ }^{246}$ Idem, 09-02-1930, pág. ?.
} 
radicalismo federal estaria aprovando uma infinidade de obras públicas, até então travadas pela falta de recursos, em todo o país. Além disso, foi denunciado que o partido estaria financiando com largas somas políticos interioranos, em troca de apoio ${ }^{247}$. Além disso, grupos opositores começavam a acusar publicamente membros personalistas de estarem criando instrumentos de fraudes eleitorais em algumas províncias.

Somando-se a toda essa situação, voltavam sempre à tona as províncias sob intervenção federal. O La Nación acreditava que os resultados dessas eleições não só colocariam à prova o personalismo naquele momento, mas romperiam barreiras criadas a anos pelo establishment radical, dando origem à maior onda opositora observada em 14 anos de radicalismo governante, o que definiria as bases para os próximos anos de governo Yrigoyen ${ }^{248}$.

No fim de fevereiro, a situação política de San Juan voltava às páginas do La Nación, que em sua capa estampava: "En San Juan fue asesinado ayer un abogado bloquista" 249 . O advogado em questão era Manuel Ignacio Castellanos, ex-juiz criminal da província de Mendoza, e ao momento de seu assassinato, o mais importante advogado de defesa do bloquismo. O La Nación classificou o crime, em resposta a uma mensagem do Ministro do Interior que definia o assassinato de Castellanos como um caso isolado e sem direcionamentos políticos, como mais um caso de barbárie política protagonizado pelo caos gerado pelas intervenções federais ${ }^{250}$.

Em 2 de março daquele ano, ocorriam as eleições eleitorais em todo o país, sob forte expectativa e também preocupação com possíveis casos de fraudes eleitorais que pudessem vir a ser praticados por ambos os lados. O jornal era bastante claro quanto ao que acreditava se a ordem do dia: desmontar as bases parlamentares que sustentavam o personalismo $^{251}$. As pesquisas iniciais indicavam a derrota do personalismo em nível nacional, o que nutria ainda mais o espírito de vigilância por parte da oposição. Os primeiros resultados a sofrerem recursos foram os de San Juan, por parte dos socialistas, que acusavam fraudes quanto ao voto secreto, que teria sido burlado por representantes radicais $^{252}$. A denúncia foi corroborada pelo jornal, que afirmou o retorno das fraudes eleitorais anteriores à Lei eleitoral de $1912^{253}$.

\footnotetext{
${ }^{247}$ Idem, 12-02-1930, pág. ?

${ }^{248}$ Editorial "El Congreso ante las próximas elecciones". Idem, 14 fevereiro 1930, pág. 8.

${ }^{249}$ Capa. Idem, 22 fevereiro 1930.

${ }^{250}$ Editorial "El país reclama hechos sin tardanza”. Idem, 23 fevereiro 1930, pág. 8.

${ }^{251}$ Editorial "El deber del dia". Idem, 02 março 1930, pág. 6.

${ }^{252}$ Capa, "Los socialistas niegan validez a la eleccion de San Juan”. Idem, 05 março 1930.

${ }^{253}$ Editorial "Infracciones electorales". Idem, 05 março 1930, pág. 6.
} 
A despeito dessa situação, o La Nación estampou em suas capas, entre 9 e 18 de março, a vitória dos partidores opositores sobre a situação em várias províncias, incluso na capital portenha, local em que o radicalismo não perdera desde sua chegada ao poder em 1926. Em todos os dados apurados, dois pontos vieram à tona, qual seja, a enorme perda de votos sofrida pelos personalistas em toda a nação e o grande crescimento eleitoral dos partidos socialistas, sobretudo em Buenos Aires ${ }^{254}$.

Em Córdoba, foi desvelado pelo juiz federal local uma violação às urnas eleitorais predicadas por homens contratados pelo governador personalista da província, que comprometeram os dados das eleições locais ${ }^{255}$. Apesar da fraude, três dos quatro senadores eleitos por Córdoba foram políticos democratas. Em 31 de março e 3 de abril daquele ano, o juiz federal responsável pelo caso mandou prender todos os oficiais e soldados da polícia local que estavam envolvidos na fraude eleitoral, e passou a investigar a ação do governador no crime ${ }^{256}$.

Enquanto as apurações das fraudes constatadas no pleito eleitoral seguiam o seu curso, durante uma manifestação organizada pelo Partido Democrata nas proximidades de Santa Rosa, em Córdoba, houve o entrechoque entre a polícia local e os oradores da manifestação, gerando atos de violência por parte da polícia que foram novamente qualificados pelo La Nación como atos de barbárie renovada 257 .

Em todo o país, grupos políticos e civis de oposição ao personalismo passaram a discutir saídas para a plena implementação da Lei eleitoral, de modo a resguardar o voto secreto. Os partidos de direita, nesse sentido, deram início aos estudos para a formação de um partido único de direita à nível nacional, que pudesse angariar maior expressão nacional para a causa. O La Nación foi um forte partidário desse movimento reivindicatório, e deu espaço em seus editoriais para a propaganda da causa da reestruturação partidária da oposição.

Em meio a tantas questões sensíveis, o governo federal voltou a falar em uma nova intervenção federal, dessa vez à província de Entre Rios. A notícia foi recebida com ira por parte dos grupos de oposição, e o La Nación dirigiu duras palavras ao governo,

\footnotetext{
${ }^{254}$ Capa. Idem, 09 março 1930; Capa. Idem, 11 março 1930; Capa. Idem, 12 março 1930; Capa. Idem, 13 março 1930; Capa. Idem, 18 março 1930.

${ }^{255}$ Capa, "Tiene ya el juez federal de Córdoba una primera prueba de la violacion de las urnas". Idem, 29 março 1930.

${ }^{256}$ Capa. Idem, 01 abril 1930; Capa. Idem, 03 abril 1930.

${ }^{257}$ Editorial "Otra vez la barbarie". Idem, 22 abril 1930, pág. 8; Editorial "Métodos siniestros". Idem, 23 abril 1930, pág. 8 .
} 
indicando que essa possível intervenção seria mais uma arma contrária à oposição que se levantava contra o personalismo nacional ${ }^{258}$.

Em 4 de maio, o governador de Santiago del Estero, Santiago Maradona, mandou fechar o parlamento da província e impediu o acesso dos parlamentares ao local, em seguida mandou enviar um comunicado ao Ministro do Interior em que pedia intervenção federal na província para reorganização do legislativo local, o qual, segundo ele, não cooperava com o executivo na aprovação de leis locais, pelo fato de ser dominado por uma maioria opositora $^{259}$. $\mathrm{O}$ ato, perpetrado por um personalista, passou a figurar naquilo que o La Nación considerava uma lista de atentados cometidos pelo personalismo radical contra a Constituição e o regime republicano ${ }^{260}$.

O governador Maradona, no entanto, foi censurado pelo presidente Yrigoyen, o que resultou na ação de retirada das forças policiais que aquartelavam o parlamento ${ }^{261}$. Ao mesmo tempo, o governo federal decidiu não mais intervir em Entre Rios, como estava sendo cogitado. Essas duas ações indicam uma leitura por parte do governo acerca da perda de popularidade do personalismo, e demonstravam, segundo o jornal, algum esforço por parte do governo em não mais tomar atitudes que fossem amplamente criticadas pelo seio social.

Entre junho e agosto, na maior parte dos dias, o jornal La Nación publicou uma gama de editoriais que visavam denunciar as ações consideradas despóticas por parte dos interventores federais nas respectivas províncias intervindas. $\mathrm{Na}$ essência, todos esses editoriais buscaram refletir a insistência por parte do personalismo em não reorganizar as instituições políticas das províncias, já sob intervenção a quase dois anos, o que demonstrava nitidamente, segundo o jornal, um desprezo do Poder Executivo nacional em relação às autonomias provinciais, bem como em relação ao Poder Legislativo. Desta forma, o La Nación advogava que o desprezo do personalismo atingia muito mais do que alguns partidos e/ou políticos específicos, mas sim todo o sistema republicano $\operatorname{argentino}^{262}$.

\footnotetext{
258 Editorial "La intervención en Entre Rios". Idem, 27 abril 1930, pág. ?; Editorial “Arbitrariedad e indecisión”. Idem, 04 maio 1930, pág. 8.

${ }^{259}$ Capa. Idem, 05 maio 1930.

${ }^{260}$ Editorial "Un atentado más". Idem, 05 maio 1930, pág. 6.

${ }^{261}$ Capa, “El P.E. desaprobo la actitud del gobernador de Santiago del Estero”. Idem, 06 maio 1930.

262 Alguns editoriais publicados nesse período sobre essas questões:

Editorial "Las províncias sojuzgadas". Idem, 23 maio 1930, pág. 8; Editorial "Escamoteo de minorías". Idem, 26 maio 1930, pág. 8; Editorial “El P.E. contra el régimen municipal”. Idem, 05 junho 1930, pág. 8; Editorial "Sometimiento incondicional". Idem, 29 junho 1930, pág. 8; Editorial "El comité y el Gobierno". Idem, 02 julho 1930, pág. 8; Editorial "La afirmación de la democracia”. Idem, 08 julho 1930, pág. 8;
} 
A ação opositora frente ao governo federal cresceu esporadicamente entre junho e agosto de 1930, firmando-se pactos e alianças políticas de oposição que transcendiam os rumos da política, atingindo até mesmo as Forças armadas, como se analisará mais à frente. Havia dentre a oposição um sentimento geral de que o governo, já a muito combalido, encontrava-se sem rumos, fosse em relação à política interna, fosse em relação às questões internacionais ${ }^{263}$. O sentimento geral de insatisfação em relação a um governo paralisado ocasionou em inúmeras formas de protestos, fosse por meio de greves, fosse por meio de manifestações, fosse por conferências políticas ${ }^{264}$.

A crescente insatisfação contra o radicalismo levou ao surgimento de dissidências no seio do personalismo dentro do próprio Congresso nacional, local que até então permanecera, por dois anos, como postos avançado e homogêneo de ação do governo federal, e principal causa de discórdia com a oposição ${ }^{265}$. No início de agosto, a oposição política formada por antipersonalistas e socialistas independentes, buscava criar ações conjuntas para a ação opositora. Ambos partidos fixavam a ideia de forçar ao máximo o personalismo a encontrar as saídas necessárias para a paralisia governamental.

Em 09 de agosto, produziu-se, por parte de uma frente ampla de oposição, composta pelo bloco de partidos de direita e pelos socialistas independentes, o conhecido "Manifesto dos 44", número de parlamentares que assinaram este manifesto, que atacava energicamente o presidente Yrigoyen e exigia que ele cumprisse integralmente a Constituição nacional e que executasse de forma plena as suas obrigações como presidente da República ${ }^{266}$.

A reação dos parlamentares personalistas foi a obstrução constante da formação de quórum no Parlamento, evitando assim o debate acerca dos temas suscitados pelo manifesto opositor. Quanto ao governo federal, conforme aponta o jornal, já havia dias que a Casa Rosada não dirigia palavras concretas sobre as questões nacionais, e principalmente, não chegou a dirigir uma resposta objetiva às reivindicações da oposição. $^{267}$

Editorial "La situación de Corrientes". Idem, 21 julho 1930, pág. 8; Editorial "Bajo la prepotencia presidencial". Idem, 28 julho 1930, pág. 4.

${ }^{263}$ Editorial "Sin rumbo". Idem, 12 julho 1930, pág. 8.

${ }^{264}$ Editorial "Agitación cívica". Idem, 02 agosto 1930, pág. 8.

${ }^{265}$ Capa, "En el Parlamento es ya visible una disidencia radical". Idem, 03 agosto 1930.

${ }^{266}$ Capa, "Con un enérgico manifiesto inician su accion coincidente diversos grupos opositores". Idem, 10 agosto 1930.

${ }^{267}$ Editorial "Sin parlamento y sin gobierno". Idem, 15 agosto 1930, pág. 8. 
Não obstante, apenas um dia após a publicação de um editorial tratando da inexistência de um governo atuante, no dia seguinte é informado que um decreto de intervenção federal em Entre Rios fora publicado, para o alento do personalismo local ${ }^{268}$. Percebe-se que o jornal não mais demonstrou surpresa em seus editoriais acerca do novo decreto presidencial de intervenção federal sem motivos claros. Em 21 de agosto, os antipersonalistas soltaram o seu manifesto, igualmente em tom de forte crítica ao governo personalista federal ${ }^{269}$.

Assomava-se, em meio a toda a agitação política e popular, um outro grupo de oposição que tomaria, dentro de poucos dias, uma decisão definitiva para os rumos políticos futuros da Argentina: trata-se das Forças Armadas, em especial o exército. Já a muitos anos, desde o início do século XX, as Forças armadas da Argentina sofreram uma brusca transformação em sua organização estrutural, sofrendo um processo contínuo de especialização, com o envio de jovens oficiais para outros países, em especial, no caso do exército, para a Alemanha ${ }^{270}$.

A profissionalização das forças armadas permitiu ensejar um forte senso de patriotismo e defesa do sistema republicano dentre aqueles jovens militares, que transmitiram os seus ensinamentos aos seus colegas na Argentina. A formação profissional dos militares argentinos, baseada também na aquisição de uma cultura letrada e política, permitiu a muitos de seus representantes se envolverem, a partir da década de 1910, com a política nacional.

Muitos desses militares, por herança familiar, possuíam íntimas relações com o radicalismo, e por isso tantos militaram nos governos radicais durante a década de 1920. Outro, ainda, colaboraram com grupos conservadores e/ou liberais, sem nunca perder o senso de pertencimento à vida militar. A maioria, no entanto, continuou neutra em questões políticas ao longo da era radical, cumprindo com o seu dever e evitando demasiada exposição dos seus pensamentos no meio social. A única exceção a esse acordo tácito dos militares se referia à representação de seus interesses junto ao governo constituído. Para tanto, a presença de um Ministro da Guerra no governo civil lhes permitia direcionar as reivindicações diretamente ao mesmo, geralmente um militar escolhido pelo governo.

\footnotetext{
${ }^{268}$ Capa, "Ha sido resuelta la intervencion federal en Entre Rios". Idem, 16 agosto 1930.

${ }^{269}$ Capa, "Aparecio ayer el Manifiesto de los Antipersonalistas". Idem, 21 agosto 1930.

${ }^{270}$ POTASH, Robert A. El ejercito y la politica en la Argentina 1928-1945: de Yrigoyen a Perón. Buenos Aires: Ed. Sudamericana. $15^{\mathrm{a}}$ ed, 1994, pág. 18.
} 
O momento mais oportuno para o desenvolvimento da vida militar durante a década de 1920 foi no governo do presidente Alvear, onde o então Ministro da Guerra, Agustín P. Justo, ex membro do Colégio Militar e expoente general da Marinha de formação anglófona, conseguiu angariar grandes conquistas para a instituição, como aquisição de novos materiais de guerra, a aprovação de um novo código militar e a mudança em cargos e salários. Porém, algumas dessas questões, iniciadas por ele, ficaram por se resolver no governo iniciado em 1928.

O novo momento político não foi do agrado da maior parte do alto oficialato militar, pois se recordavam dos tempos amargos que passaram sob a primeira presidência de Yrigoyen. Apesar de os ganhos salariais terem sido maiores com o novo governo de Yrigoyen do que com o de Alvear, em diversos outros pontos o novo governante acabou por destituir regras básicas da ordenação militar, algo muito apreciado por um militar de carreira, mas não tão observado por civis, como acabou por se mostrar.

O jornal La Nación rememorou em diversas ocasiões algumas decisões tidas como conflituosas para com o corpo militar, as quais foram resumidas por Robert Potash:

Desde el punto de vista del oficial común era mucho más grave la manifestación de favoritismo político en el tratamiento del personal militar. Este favoritismo adoptaba diferentes formas: la reincorporación al cuerpo de oficiales de personal dado de baja hacía mucho tiempo, con reconocimiento integral de los años transcurridos entretanto; la promoción retroactiva de oficiales retirados, en oposición a cláusulas explícitas de los reglamentos militares, con derecho a percibir el diferencial en la situación de retiro, y la modificación de la fecha de ascenso de los oficiales en servicio activo que gozaban de favor, medida que les otorgaba mayor antiguedad que a sus contemporáneos, y por consiguiente ventajas en los ascensos. ${ }^{271}$

As mudanças impostas por Yrigoyen ao corpo e disciplina militares, muitas vezes, como sinalizado por Potash, apenas em favorecimento de grupos aliados ao personalismo, ajudaram a levar as Forças armadas ao cerne da crise institucional vivida nos dois anos de seu segundo governo. A inserção dos militares nesse turbulento grupo abalou seriamente as bases sobre as quais se assentava o serviço militar argentino até então: ordem, disciplina e respeito à ordem constitucional.

O jornal não deixou de observar o crescimento do envolvimento dos militares com os rumos políticos do país, e o fez com elevada preocupação:

Una dolorosa experiencia motivó hace 25 años la sanción del art. $6^{\circ}$ de la ley orgánica militar que todavía rige, por el cual los militares en actividad "no pueden tomar, directa ni indirectamente, participación

${ }^{271}$ Idem, pág. 61. 
alguna en politica"(...) La politica ha invadido, pues, al ejército. La Constiución, las leyes militares y los reglamentos vigentes han sido violados cuantas veces fué necesario para servir esa política. Como una consecuencia forzosa, esta deporable acción de la superioridad ha ido quebrando la unidad del ejército, introduciendo una peligrosa división en su seno, por los favoritismos de que disfrutan los allegados y la desconsideración de que se hace objeto a los que no lo son. (...) Antes habia unicamente militares argentinos; ahora hay militares gobernistas y militares opositores, militares favorecidos y militares perseguidos. (...) los verdaderos militares, que todavía los hay, aquellos que ajenos a los intereses de toda politica partidaria sólo proceden inspirados por las necesidades del ejército y en el prestigio del país, tienen la obligación ineludible de concentrar todos sus esfuerzos a fin de evitar mayores males. (... $)^{272}$

O envolvimento dos militares com a política nacional foi em parte propositada por aquelas ações advindas do governo federal em uma década de radicalismo, que causaram reações negativas no seio do oficialato, quanto por parte, sobretudo nos anos finais da década de 1920, da ação de grupos civis e intelectuais militaristas ligados ao nacionalismo, dentre eles Leopoldo Lugones. Em pouco tempo, a oposição pública de parte dos militares à Yrigoyen, iniciada em meados de 1929, assumiu contornos mais drásticos já a partir do início de 1930, e rapidamente a ideia de dissolução do governo pelas Forças Armadas ganhou força dentre os militares líderes daquela oposição.

A oposição militar, no entanto, não era homogênea. O corpo militar estava dividido, basicamente, em dois grupos, liderados, respectivamente, pelo tenente-coronel da reserva do Exército, José Félix Uriburu, e pelo general da Marinha e ex-ministro da Guerra durante o governo de Alvear, Agustín P. Justo. Suas ações e perspectivas de rumos a serem adotados no Estado argentino diferiam sensivelmente, em grande parte por conta das diferenças ideológicas de seus líderes. O único ponto de concordância entre ambos concernia à necessidade de uma urgente intervenção militar e à destituição do Poder executivo federal ${ }^{273}$.

O primeiro grupo era favorável à introdução de uma junta de governo militar após a renúncia de Yrigoyen, a qual seria presidida pelo próprio Uriburu. Secretamente, esse grupo, mais próximo dos intelectuais nacionalistas, era favorável a uma completa reestruturação do Estado, onde a democracia de massas daria lugar a um sistema corporativista similar ao fascista italiano ${ }^{274}$. Já o segundo grupo, liderado pelo anglófono

\footnotetext{
${ }^{272}$ Editorial "El ejército y la politica". La Nación, 12 março 1930, pág. 6.

${ }^{273}$ POTASH, Idem, pág. 71.

${ }^{274}$ Idem, pág. 72.
} 
general Justo, considerava que o envolvimento dos militares com o poder civil deveria ser o mais breve, e se restringiria a empossar provisoriamente o presidente do Senado como presidente da República e a convocar novas e rápidas eleições, segundo previsto pela Constituição nacional ${ }^{275}$.

O debate entre os dois grupos se desenrolou ao longo dos primeiros meses de 1930, e logo seus ecos começaram a serem ouvidos fora dos muros dos quartéis. Alguns partidos se aproximaram dos militares conspiradores, dentre eles o Partido Conservador de Buenos Aires ${ }^{276}$. Outros, no entanto, não apresentaram posicionamentos claros antes de 8 de setembro, porém, em sua maioria, acabaram por se enamorar com o futuro governo militar e a reordenação administrativa do país, ao menos em seus primeiros meses.

Quanto ao La Nación, como se faz sentir pelo editorial acima publicado, ainda que pudesse ter conhecimento prévio da conspiração militar contra o governo, o que não se confirma por meio das fontes editoriais, é certo que o mesmo não apoiou prontamente a solução militarista. O mesmo pode ser observado nas inúmeras reportagens publicadas pelo jornal acerca da situação política da Bolívia e Peru, dois países que haviam acabado de sofrer intervenções militares, os quais eram embebidos de uma visão crítica e negativa quanto às vias não democráticas e constitucionais.

Os dois grupos militares conseguiram chegar a um acordo mútuo nas semanas imediatamente anteriores ao 8 de setembro ${ }^{277}$. Ficou acordado que uma junta militar se formaria a fim de se reorganizar, com o tempo necessário, a estrutura administrativa e governamental, e que Uriburu se tornaria o presidente de facto do país durante essa transição. Não obstante, a Constituição nacional não sofreria mudanças e o Congresso não seria fechado, mantendo-se assim o estado de liberdades políticas intacto. Por fim, novas eleições seriam convocadas assim que o fosse possível. Feitos os acordos finais, tudo já se encaminhava para o fim.

No dia 28 de agosto, o La Nación já observava uma “desusada actividad” com as atividades policiais em Buenos Aires, pois havia um ar de vigilância pairando sobre a polícia local, que começava a preparar medidas de proteção na região próxima à Casa Rosada $^{278}$. No dia anterior, ocorrera no Teatro Pueyrredón uma assembleia geral das

\footnotetext{
275 Idem, pág. 73.

276 Idem, pág. 78.

277 Idem, pág. 76.

${ }^{278}$ Capa. La Nación, 28 agosto 1930.
} 
direitas, na qual discursaram diversos líderes e parlamentares desses partidos, com um tom geral de insatisfação com o governo. Porém, a assembleia ficou marcada por diversas manifestações contrárias à uma possível "revolução" militar, como se percebe nas falas do deputado socialista independente Roberto F. Giusti e do líder democrata González Iramain. ${ }^{279}$

O La Nación, em editorial do dia 29 de agosto, voltou a se referir com intensa preocupação às movimentações militares que começavam a ganhar corpo:

No podemos admitir, no debemos admitir la posibilidad o la utilidad de soluciones que estén en contra de los métodos que emanan de nuestra estructura democrática, en contradición con los medios que las instituciones ofrecen al ciudadano para corregir a los gobiernos abusivos. $\left(. .{ }^{280}\right)($ Grifo Meu $)$

O sentimento de tensão continuou a se alastrar com maior intensidade nos dias seguintes. Em 29 de agosto, o jornal estampava a prisão de "varios jefes y oficiales del ejército”, por ocasião de uma tentativa de acesso ao Ministério da Guerra, o que foi negado aos postulantes, levando a um breve conflito entre estes e os guardas locais ${ }^{281}$. Na mesma edição, o La Nación destacava o aumento da preocupação internacional em relação à delicada situação política vivida na Argentina. Interessa observar que, segundo apurado pelos correspondentes internacionais do jornal, a maior parte dos órgãos midiáticos estrangeiros culpavam o Ministro do Interior por grande parte dos problemas vividos na nação, e culpavam ainda mais ao presidente Yrigoyen por sua intransigência em retirá-lo do governo e buscar uma aliança com a oposição. ${ }^{282}$

O dia 30 de agosto surgiu com a praça de maio, circunvizinha à Casa Rosada, isolada pela polícia de Buenos Aires. O presidente da República, por sua vez, não fez o seu despacho diário. O Ministro do Interior convocou, sob ordem de Yrigoyen, o general Justo para prestar esclarecimento acerca de seu suposto envolvimento na trama militar que já se desvelava. Justo teria argumentado que, mediante a situação política criada pelo próprio governo, não lhe estranhava que essa acusação recaísse sobre si, devido não aos fatos, mas sim a um estado de nervosismo que tomara conta dos políticos governantes ${ }^{283}$. Apesar do tom de desconfiança, comentou-se que o real motivo da reunião secreta com Justo seria a destituição do Ministro da Guerra e o oferecimento do cargo a aquele.

\footnotetext{
279 POTASH, Idem, pág. 32.

${ }^{280}$ Editorial "La situación del país". Idem, 29 agosto 1930, pág. 8.

${ }^{281}$ Capa. Idem, 30 agosto 1930.

${ }^{282}$ Idem.

${ }^{283}$ Capa. La Nación, 31 agosto 1930.
} 
Desde Paris, comentava-se diariamente a efervescência militar na Argentina e em toda a América do Sul. Peru e Bolívia já se encontravam sob recentes regimes militares impostos, no Chile e no Brasil determinados grupos militares assombravam a ordem institucional estabelecida, e na Argentina os rumos pareciam se encaminhar para o mesmo fim $^{284}$. Nas ruas de Buenos Aires, seguidores de Yrigoyen organizavam, diariamente, manifestações pró-governo, nas quais se verificavam a presença onipresente de retratos do presidente ${ }^{285}$.

O Ministro da Guerra, convencido da ação conspiratória e do iminente golpe militar, aconselhou ao presidente a rápida tomada de atitudes contrárias aos militares conspiradores, prendendo os seus líderes e, por outro lado, impondo radicais mudanças ao gabinete de governo. Yrigoyen se recusou a seguir este conselho, o que levou à renúncia de Dellepiane do Ministério da Guerra em 2 de setembro ${ }^{286}$. Entre 4 e 5 de setembro, grupos de estudantes tomaram as ruas exigindo a imediata renúncia do governo, gerando entrechoques entre estudantes e policiais. Em 5 de setembro, devido ao estado de enfermidade em que se encontrava, o presidente Yrigoyen delegou as funções presidenciais ao vice-presidente Martínez, o qual decretou imediatamente estado de sítio em Buenos Aires. ${ }^{287}$

Em 5 de setembro, em meio à agonia do governo radical, o manifesto revolucionário dos militares, redigido pelo poeta Leopoldo Lugones, chegaria a sua forma final, não sem antes gerar sérios debates entre os setores aliados de Uriburu e Justo quanto à determinadas partes do texto, as quais foram revisadas de modo a alocar os interesses de ambos os grupos ${ }^{288}$. Dentre as decisões chaves das últimas conferências dos militares, ficara decidido que a "revolução" a ser desencadeada deveria seguir os mesmos rumos daquela que uniu opositores e pôs abaixo o governo de Celman em 1890, dentre os quais assomava o papel civil como fator preponderante para a legitimação do movimento. ${ }^{289}$

Na manhã de 6 de setembro os militares se preparavam para concretizar a conspiração. Não obstante a concordata entre as duas facções militares proponentes do golpe, ainda pairava no ar daquela manhã a sensação de indecisão, sobretudo no que

\footnotetext{
${ }^{284}$ Idem.

${ }^{285}$ Editorial "El retrato en la calle”. Idem, pág. 6.

${ }^{286}$ POTASH, Idem, pág. 79.

${ }^{287}$ LUNA, Félix. Historia Integral de la Argentina: Conservadores y Peronistas. Tomo IX. Buenos Aires: Editorial Planeta Argentina, 1997, pág. 14.

${ }^{288}$ ROUQUIÉ, Alain. Poder militar y sociedad política en la Argentina: hasta 1943. Buenos Aires, Emecé, 1994, pág. 196.

${ }^{289}$ Idem.
} 
consta à adesão de generais legalistas, tal como o general Álvarez, comandante da guarnição que chefiava a praça de Maio e as imediações da Casa Rosada ${ }^{290}$. Além disso, muitos militares veteranos, dentre os quais alguns aliados históricos do radicalismo, ainda aparentavam um forte ceticismo quanto à necessidade da intervenção. Mas o plano deveria ser executado até o fim.

Foi nos jovens cadetes e tenentes do exército, concentrados sobretudo no Colégio Militar, que o general Uriburu encontrou seus mais entusiastas seguidores. Para aquela instituição rumaram também centenas de civis, especialmente estudantes ${ }^{291}$, animados em participar da derrocada do governo. Para os civis, Uriburu fez distribuir cerca de 500 armas, e terminado os preparativos, liderou-os, ao lado de mais de 600 cadetes e oficiais do Colégio Militar ${ }^{292}$ e outros 800 soldados liderados pelo tenente coronel Pedro Rocco, em sua "marcha sobre Buenos Aires" rumo à Casa Rosada, onde seria exigida a renúncia à força ${ }^{293}$.

A marcha de Uriburu e de seus seguidores não encontrou resistência nas ruas portenhas, à exceção de um breve tiroteio na praça do Congresso, que ocasionou na morte de dois cadetes e em alguns civis feridos ${ }^{294}$. Por fim, o grupo marchou sobre a praça de Maio e adentrou pelas portas da Casa Rosada, onde o presidente em exercício Martínez assinou a sua renúncia e do governo. Yrigoyen já havia sido evacuado para La Plata antes da chegada de Uriburu, e de lá aguardaria o seu destino ${ }^{295}$. O tenente-coronel José F. Uriburu assumiu a presidência da República e instituiu o governo provisório. O golpe militar de 6 de setembro de 1930 estava consolidado. Aquela noite foi marcada pelo ataque de civis ligados aos militares aos prédios dos jornais radicais "La Epoca" e "La Calle", e também pela destruição da residência pessoal do presidente deposto ${ }^{296}$.

A inexistência das edições do jornal relativas ao mês de setembro de $1930^{297}$ não nos permite analisar com exatidão os posicionamentos do jornal com relação à chegada

\footnotetext{
${ }^{290}$ Idem.

291 Caras y Caretas. 13 setembro 1930, n. ${ }^{\circ}$ 1.667, pág. 68. Disponível em: http://hemerotecadigital.bne.es/issue.vm?id=0004697977\&search=\&lang=es . Acesso em: 23 abril 2015.

${ }^{292}$ LUNA, Historia Integral, Idem, pág. 16.

${ }^{293}$ ROUQUIÉ, Idem, pág. 197.

${ }^{294}$ Idem, pág. 198.

${ }^{295}$ Idem.

${ }^{296}$ Caras y Caretas, Idem, 13 setembro 1930. págs. 80-81.

${ }^{297}$ O microfilme que contém as edições do La Nación relativas aos meses finais de 1930 na Hemeroteca da Biblioteca do Congresso de La Nación não possui as edições do mês de setembro. Observa-se que, em contraste com a maior parte das edições dos anos anteriores preservadas nos arquivos, mesmo as edições de outubro estavam em mal estado de preservação no momento de sua microfilmagem, onde muitas das páginas do jornal se encontravam rasgadas ou pela metade. Infelizmente, a falta das edições de setembro também se verificou em outras hemerotecas de Buenos Aires.
} 
dos militares ao poder, no entanto, infere-se das edições posteriores do diário que a intervenção militar não foi observada com surpresa pelo mesmo, ainda que os rumos posteriores ao golpe fossem de seu imediato interesse.

Em meio ao processo de reorganização da estrutura administrativa do país, que levou à intervenção federal em praticamente todas as províncias, bem como à manutenção do estado de sítio em todo o país, o jornal pautou, nas semanas posteriores ao golpe militar, a imediata necessidade de se garantir a constituição federal e de se retomar a normalidade pública.

No dia $1^{\text {o de outubro, o jornal estampava }}{ }^{298}$ o manifesto do governo provisório, assinado pelo presidente Uriburu, em que se buscava garantir à nação o respeito à Constituição e às prerrogativas dos demais poderes, em especial o Legislativo, que passaria por novas eleições. Em seu editorial, o La Nación recebeu o manifesto com relativo ânimo, no entanto, não deixou de pontuar que, tão importante quanto a garantia de novas eleições para o Legislativo nacional, fazia-se também urgente novas eleições para o Executivo nacional:

Ese procedimiento no es el que se esperaba. No basta que el gobierno provisional asegure que acatará todas las resoluciones del Congreso, porque lo considerará "el depositario de la soberania nacional". Lo que esperaba el pueblo es que el gobierno emanado de la revolución que puso término a un régimen funesto restituyese a la República la normalidad institucional, convocando a elecciones para constituir el Poder Ejecutivo y el Legislativo, y no unicamente este último. ${ }^{299}$

Durante os dias seguintes, o jornal voltou a assumir a mesma posição, e passou a dar reiterado apoio à Federação Nacional Democrática, frente única opositora que reunia antipersonalistas e socialistas independentes e que tinha por meta organizar um novo governo constitucional. O primeiro ato do governo provisório foi garantir a legitimidade da intervenção, o que envolveu uma ampla investigação policial dos documentos secretos da União Cívica Radical, reuniões com membros de diferentes instituições nacionais, incluso a própria mídia ${ }^{300}$, e a cooperação com grupos civis, em especial as brigadas paramilitares da Liga Patriótica ${ }^{301}$.

Outra atitude tomada pelo novo governo foi utilização da memória histórica nacional como fator legitimador do regime, ao reforçar, com apoio de renomados

\footnotetext{
${ }^{298}$ Capa. La Nación, 01 outubro 1930.

${ }^{299}$ Editorial "El manifiesto del gobierno provisional”. Idem, pág. 10.

${ }^{300}$ Idem, 02 outubro 1930, pág. 2.

${ }^{301}$ Idem.
} 
intelectuais, a semelhança da "revolução de 6 de setembro" com os acontecimentos que levaram à revolução do Parque em 1890 e à queda de Juárez Celman da presidência ${ }^{302}$. Deste modo, a queda de Yrigoyen e do governo constitucional poderia ser interpretada pela população como um novo capítulo na história cívica do país. No entanto, os rumos posteriores ao golpe, não abarcados neste trabalho, mas amplamente documentados e analisados pela historiografia, demonstraram, tanto para o povo quanto para o jornal, que muitas de suas esperanças, brevemente exaltadas pela queda dos radicais, logo se transmutariam em desesperança e ligeira melancolia nos anos seguintes. ok

O jornal La Nación teve uma ação opositora constante e impiedosa em relação ao governo de Yrigoyen, mas não era seu objetivo derrubá-lo pelo uso da força. O jornal atuava, sim, em favor da reconstituição da oposição política representada no Poder Legislativo e a contenção dos atos considerados imorais por parte do Poder Executivo, dentre elas as intervenções federais arbitrárias nas províncias, com finalidades políticas; a manobra dos parlamentares governistas a fim de impedir os debates legislativos e a ingerência administrativa verificada ao longo dos dois anos do governo. Muitas vezes, os problemas relativos à administração pública federal eram atribuídos à própria idade, que tinha como consequência uma suposta incapacidade de liderança por parte do presidente.

A queda de Yrigoyen criou numa nova realidade política para a nação argentina. O 6 de setembro de 1930 elevou, em definitivo, as Forças Armadas ao status de protagonista político nacional, o qual seria responsável por muitas outras intervenções armadas até a década de 1980. Aquele, no entanto, eternizou-se na memória coletiva do país, vide a grande comoção popular que tomou as ruas de Buenos Aires quando de sua morte em 1933, e inspirou alguns jovens políticos que mais tarde acenderiam no palanque político nacional, dentre eles Juan Perón, que em 1930 assistiu ao golpe como um dos oficiais envolvidos na coordenação da intervenção, e dele retirou muitos ensinamentos que lhe seriam úteis no futuro. Definitivamente, o ano de 1930 ficou encravado com letras de fogo na história da Argentina e de diversas gerações.

\footnotetext{
${ }^{302}$ Idem.
} 
Conclusão

Este trabalho surgiu do esforço de se elucidar os posicionamentos políticos construídos pelo jornal La Nación em relação ao segundo governo de Hipólito Yrigoyen, entre 1928 e 1930. Foram observados determinados aspectos fundamentais à compreensão de sua atuação por meio das fontes levantadas, a saber, o conteúdo de seus 
editoriais e a veiculação e repercussão dos mesmos em meio aos principais grupos políticos e econômicos do país.

Buscando compreender a origem das principais questões existentes e dos grupos políticos centrais, todos ainda em ação em 1930, analisou-se no primeiro capítulo os antecedentes históricos do país. Em especial, observou-se os debates acerca da natureza do Estado argentino, mergulhado em embates entre centralistas portenhos e federalistas, o processo de constituição política da Argentina em meados do século XIX, após a concordata entre os generais Urquiza e Bartolomé Mitre, os constantes conflitos envolvendo diferentes grupos políticos locais no alvorecer da jovem nação, o início do período de hegemonia autonomista, as tramas revolucionárias e o surgimento da União Cívica Radical.

Percebeu-se, após análise desse contexto, que a Argentina, quanto nação unificada e reconhecida sob a égide de um mesmo corpo de leis para todas as províncias, é o resultado de intensos debates políticos e confrontos armados que protagonizaram a paisagem daquela região entre 1810 e 1862 . O processo de independência das Províncias Unidas do Rio da Prata, antes reunidas sob o título de Vice-Reino espanhol do Rio da Prata, desenrolado a partir de 1810, abarcou em si inúmeras perspectivas nacionais quanto à formação do novo país. Em seu bojo, ascenderam dois grupos antagonistas: os federalistas e os unitários.

Enquanto o federalismo, forte corrente ideológica das províncias interioranas e de suas elites, defendia a constituição de um Estado de modelo federalista, isto é, com um poder central limitado que garantisse a autonomia das províncias, os unitaristas, fortemente concentrados em torno do outrora cabildo de Buenos Aires, lutavam pela formação de um Estado centralizado em torno da cidade portenha, a qual, como antiga capital do Vice-Reino do Rio da Prata, possuiria as condições naturais para a condução da nova nação.

A luta entre federalistas e unitários atravessou toda a primeira metade do XIX, e dela sucedeu a ascensão do caudilho e ditador Juan Manuel de Rosas, que governou por duas décadas a mão de ferro o país ainda disforme e sem uma identidade em comum. $\mathrm{O}$ regime rosista, de retórica federalista e temperamento unitário, foi o principal propulsor dos grupos políticos que atravessariam as décadas seguintes, neste momento divididos 
entre situação e oposição. Dos grupos rosistas surgiriam, anos mais tarde, os nativistas ${ }^{303}$, os radicais e, posteriormente, os primeiros nacionalistas. Já daqueles opositores ao rosismo, surgiria toda a tradição liberal-conservadora que se tornaria hegemônica na Argentina entre 1862 e 1916. De ambos os grupos surgiram intelectuais e políticos que dominaram o país durante o período liberal-conservador, dentre eles, Bartolomé Mitre e Domingo Faustino Samiento, primeiros presidentes da República argentina, Julio A. Roca, fundador do autonomismo, e muitos outros.

A queda de Rosas em 1852 após a derrota na batalha de Caseros para as tropas argentino-brasileiras lideradas pelo general Urquiza, reabriu as discussões entre os expoentes daquelas duas facções ideológicas históricas. O federalismo acabou por se atrelar a Urquiza, o qual assumira para si a liderança do país após a derrota de Rosas, o que gerou fervorosa oposição dentre os grupos portenhos, de tradição unitária. Em meio às querelas resultantes desse embate, resultou a formação de dois Estado autônomos por um período de uma década, a Confederação argentina, sob a liderança de Urquiza e reunindo todas as províncias à exceção de Buenos aires, e a província de Buenos aires, sob liderança do jovem Mitre e do histórico Sarmiento.

O projeto de unificação nacional apenas se articulou em meados de 1861 após a batalha de Pavón, com a paz entre Mitre e Urquiza, o qual se retirou da cena nacional e viveu até a morte em sua província natal de Entre Rios. Buenos aires aceitara a Constituição de 1853 criada pela Confederação argentina, em troca, porém, assumira para si a liderança do país, o que não deixou de gerar repercussões negativas nas demais províncias. Bartolomé Mitre foi eleito, então, o primeiro presidente da nação unificada no ano de 1862, tendo lidado com questões internacionais de grande impacto, em especial a Guerra do Paraguai, e com inúmeras insurreições federalistas no interior.

Foi sucedido por Sarmiento, e em seu breve retiro político, Mitre fundou, em 1870, o jornal La Nación, com o objetivo de criar um veículo de imprensa com doutrinas e posicionamentos claros e engajado protagonismo cultural. A condução do jornal esteve a cargo do próprio Mitre ao largo de muitos anos, e somente em sua velhice transmitiu a liderança para os seus descendentes, os quais ainda hoje comandam o jornal.

O período entre 1862 e 1880 assistiu às primeiras mudanças no seio nacional. As relações comerciais com a Inglaterra começavam a ganhar impulso e o projeto de uma

\footnotetext{
${ }^{303}$ Considera-se por nativismo, segundo Shumway e Quattrovicci-Woisson, os grupos de intelectuais hispanistas que ganhariam corpo no início do século XX, especialmente em torno de figuras como Ricardo Rojas e Manuel Galves.
} 
grande nação, capaz de fazer frente ao Império do Brasil na liderança regional, alimentava os esforços dos primeiros governantes. A luta pela hegemonia sul-americana levaria essa geração de políticos a se depararem com duas grandes barreiras: o território limitado e a falta de mão-de-obra capacitada. Um nascente grupo social, formado por jovens representantes das elites agrárias, compreendera melhor do que os seus contemporâneos as saídas para os entraves ao desenvolvimento nacional. Seus representantes se aglutinaram em torno do Partido Autonomista Nacional, PAN, e chegaram ao topo do poder federal em 1880 com a eleição de Julio Argentino Roca para a presidência da República.

Esse período, de tal forma heterogêneo e complexo, confunde-se, muitas vezes, sob a persona de Roca, o qual governaria ainda mais uma vez o país no fim do século. Foi ele o primeiro governante a decidir expandir o país rumo ao sul e nordeste, respectivamente para a Patagônia e o Chaco. Com essa expansão, Roca buscava ampliar a oferta de terras produtivas e propiciar, desta forma, a atração por mão-de-obra estrangeira. A região patagônica, principal foco de Roca, graças ao seu clima temperado, propício à produção de grãos e cereais, era densamente habitada por populações indígenas, e sua existência era encarada como um empecilho para o progresso nacional.

O governo roquista despejou, no início da década de 1880, diversas expedições militares em direção à Patagônia, que levaram ao gradual extermínio das populações locais e à anexação destes territórios à federação. O surgimento de novos territórios agrários propiciou a aprovação de leis de imigração no Congresso e o financiamento de levas imigratórias, oriundas, principalmente, da Europa setentrional. Milhões de imigrantes seguiram para a Argentina e engrossaram a sua crescente mão-de-obra, tornando esse país o segundo maior em taxas de imigração, atrás somente dos Estados Unidos da América.

A ampliação do território nacional e o aumento da mão-de-obra permitiram a rápida expansão da produção de carnes, grãos e cereais, que eram muito superiores à demanda interna. Esse fator levou ao estreitamento dos laços comerciais do país com o Império britânico, que passou a consumir grande parte das exportações locais em troca da venda de produtos industrializados e do incremento dos investimentos em infraestrutura por parte de empresas britânicas, especialmente no setor ferroviário, tão necessário em um país de grandes extensões como a Argentina. Foi essa aproximação, seguida de um grande fluxo de capitais ingleses, que dotaram o país dos instrumentos 
necessários para o rápido enriquecimento e progresso material verificados entre o fim do século XIX e as primeiras décadas do XX.

Todavia, apesar dos grandes progressos observados durante o governo de Roca, o período imediatamente posterior ao fim da sua presidência foi marcado por grande agitação política e social, culminando nos eventos que desencadearam a Revolução do Parque de 1890. Esses eventos foram cruciais para o futuro político do país sobretudo pela ascensão ali verificada de novas personagens políticos, sobretudo dentre as camadas médias urbanas, que estavam em franco crescimento devido à chegada de mais e mais imigrantes nas cidades, em especial Buenos aires. Foi ali que surgiu a União Cívica Radical, liderada por Leandro Alem e outros políticos já antigos que possuíam um grande apelo popular. A UCR surgiu com o objetivo de não coadunar com a política eleitoral fraudulenta que era praticada pelas elites políticas, e por isso seguiu, por muitos anos, a via revolucionária e intransigente.

Ao lado de Alem seguia, desde muito cedo, seu sobrinho Hipólito Yrigoyen, que com ele aprendera a fazer política e a lidar com os apelos populares. Após a morte de Alem, Yrigoyen assumiu a liderança da UCR, e pouco-a-pouco imprimiu-lhe as suas marcas pessoais. Ao lado de seu amigo e discípulo Marcelo T. de Alvear, arquitetou diversas revoluções armadas contra o regime governante, como em 1905, na qual fora preso e, em seguida, anistiado, devido à comoção pública gerada. Percebendo que a “política de notáveis" já não era mais capaz de lidar com a constante pressão popular por maior participação política, sobre a qual se assentavam os líderes radicais, o presidente Roque Sáenz Peña foi o responsável por arquitetar e aprovar a lei de reforma eleitoral de 1912, que estabelecia o sufrágio universal e o voto secreto e obrigatório para todos os homens.

A Lei eleitoral de 1912, também chamada de Lei Sáenz Peña, trouxe ao cenário político um grande número de eleitores do radicalismo, os quais foram os responsáveis pela eleição de Hipólito Yrigoyen à presidência da República em 1916, pondo fim a quase quatro décadas de hegemonia autonomista. No segundo capítulo deste trabalho, analisouse a ascensão do radicalismo ao poder e a aglutinação das oposições políticas a UCR em torno de grupos, partidos e veículos de comunicação impressa, dentre eles o jornal La Nación.

O período que se estende de 1916 a 1930 marcou a hegemonia radical no poder, bem como grandes mudanças na política interna e externa do país. O primeiro governo de Yrigoyen se estendeu de 1916 a 1922, e se denotou pela brusca queda nas exportações, 
consequência do cenário pós-Primeira Guerra Mundial e do enfraquecimento de seu principal mercado consumidor, o britânico. Devido à queda nas exportações agropecuárias e à consequente diminuição da importação de produtos industrializados ingleses, o país se viu obrigado a encontrar novas soluções, levando ao aumento dos investimentos estatais e da abertura de crédito para a indústria local. Com o tempo, o enfoque na indústria nacional e na participação estatal na economia, marcas identitárias dos governos radicais, acabou por repercutir negativamente em meio aos grupos agropecuaristas e às indústrias estrangeiras.

No campo da política, observou-se a dinamização de práticas clientelistas pelo governo de Yrigoyen, bem como da instrumentalização do mecanismo constitucional das intervenções federais, amplamente utilizadas em províncias controladas pela oposição sob argumentos frágeis, costumeiramente sem a aprovação por parte do Congresso, conforme previa a Constituição nacional. Além disso, a personalidade marcante do presidente, com sua característica personalista, gerou fortes cisões no seio da própria UCR durante esse período, levando posteriormente à separação dos autodenominados antipersonalistas durante as eleições de 1924.

Em 1922, com o fim do mandato presidencial de Yrigoyen, foi eleito para a presidência da república o também radical Marcelo T. de Alvear, de linha antipersonalista e menos intransigente. Seu governo foi marcado, no campo político, pela abertura de diálogo com a oposição e pela reestruturação da máquina pública, atitude elogiada fortemente pelo La Nación e demais grupos não radicais. No campo econômico, o período alvearista conheceu um breve e instigante impulso nas exportações agropecuárias, reaproximando a nação da Inglaterra, ainda que com a presença cada vez mais marcante dos capitais norte-americanos no país.

O governo de Alvear chegou ao fim em 1928. Seu sucessor natural era Yrigoyen, o que se concretizou nas eleições presidenciais de 1927, findadas com ampla vitória do personalismo, que se acostumou a chamar essas eleições de "plebiscito". Aqui se encontra o objeto desta pesquisa, e parte central do estudo. O terceiro capítulo analisa, de forma pormenorizada, o segundo governo de Yrigoyen sob a percepção do jornal La Nación, com sua grande presença entre os meios letrados e mais abastados da capital. Mais ainda, buscou-se defrontar os questionamentos que iniciaram esse esforço de pesquisa, quais sejam, as atitudes do jornal em relação a este governo e o envolvimento, ou não, do mesmo na intervenção militar de 1930. 
As eleições presidenciais e provinciais, iniciadas no início de 1928, deram o tom do posicionamento dos conflitos políticos alimentados desde 1916. Primeiramente, com o silêncio do presidente Alvear em relação ao futuro candidato do radicalismo, e também com a aglutinação das forças de oposição, nomeadamente os antipersonalistas, socialistas independentes, liberais e conservadores, em torno da fórmula presidencial antipersonalista. Desde cedo, o jornal se fez muito assertivo em relação às eleições próximas, e seu apoio indireto à oposição estava presente nas diversas análises políticas de seus editoriais.

O lançamento oficial da candidatura de Yrigoyen à presidência da República, realizado poucos dias antes da composição do Colégio eleitoral, não foi bem recebido pelo jornal. Sua ação de apoio à oposição se tornou ainda mais tácita, e sua vigilância em torno das movimentações do candidato radical e de seus seguidores ficou redobrada. A vitória radical nos pleitos, no entanto, não causou estranheza no jornal, que considerou o resultado final menos estarrecedor do que o esperado. A formação de uma frente única de oposição e a vitória opositora no Senado nacional, ao contrário, permitiram ao La Nación manter-se esperançoso quanto ao novo governo, que precisaria se manter em diálogo com a oposição para garantir a governabilidade do país nos anos seguintes.

Os 23 meses de governo yrigoyenista foram minuciosamente destrinchados e passados a limpo nos editoriais diários do jornal. As questões de foro político, econômico e administrativo foram constantemente alvos de perspicazes análises e retóricas que beiravam a beligerância em relação ao governo federal. De todos os temas observados, destacou-se o papel das intervenções federais, cujos propósitos e desenrolar foram firmemente rebatidos pelo diário, seja pela inexistência de motivos, seja pela forma como foram conduzidos.

As intervenções federais às províncias de San Juan e Mendoza, desencadeadas ainda no início do novo governo, foram, a priori, bem quistas pelo La Nación, devido ao estado de exaltado ânimo verificado entre as facções radicais rivais ali presentes, onde dominavam as facções radicais bloquista e lencinista, respectivamente. O jornal não deixou de apontar o interesse por parte do governo federal em conter o avanço de ambas facções, que haviam cindido com o oficialismo radical e apoiado a oposição antipersonalista nas últimas eleições, em um misto de precaução e vingança.

Outras intervenções federais foram decretadas ao longo dos meses seguintes, acirrando ainda mais os ânimos políticos em todo o país. O jornal, veemente em sua crítica aos atos do governo, observava um desponte de autoritarismo semi-ditatorial por detrás 
dos atos proclamados pelo governo central, dado o fato de que grande parte dos decretos presidenciais de intervenção foram firmados e executados sem a prévia análise do Parlamento, muitas vezes mesmo em meio aos seus recessos legislativos.

O papel das relações institucionais entre o parlamento e o governo federal também foi alvo de reiteradas análises editoriais. Ficou perceptível que para o jornal, o papel desempenhado pelo poder Legislativo nacional, essencial para o bom funcionamento das instituições republicanas, estava sendo cooptado e mesmo anulado pelas ações do poder Executivo. Salta aos olhos, como ressalva a esse posicionamento, a crise gerada em torno da convocatória da sessão legislativa de 1929 e da pauta prioritária, defendida pela oposição, em torno da votação dos diplomas dos senadores de Mendoza e San Juan.

A crise, que durou algumas semanas, foi desencadeada pela intransigência dos deputados governistas em aceitar iniciar as discussões, o que desencadeou os sucessivos adiamentos das sessões de debate por conta da falta de quórum, oriunda das faltas em massa da base governista. O jornal fez incisivas denúncias de que essa situação respondia a uma possível orientação oriunda da Casa Rosada, que não tinha interesse em iniciar as votações dos diplomas, o que corresponderia a uma intromissão inconstitucional do Executivo federal sobre o Legislativo, enfraquecendo assim a harmonia dos poderes.

O Legislativo era o bastião da República segundo a visão do jornal. Nele residia a obrigação de manter o Poder Executivo limitado às suas obrigações constitucionais, e também o papel de juiz dos maus atos praticados pela administração federal. Assim defendeu com veemência o La Nación ao largo de todo esse período, e suas denúncias contra o governo federal sempre se dirigiam aos parlamentares, fosse em face do autoritarismo verificado nas intervenções federais, repletas de casos de perseguição política e censura da liberdade de imprensa, fosse em face da má gestão da máquina pública, dos interesses nacionais frente a outras nações e dos problemas econômicos que assolavam o país.

O ano de 1930, marcado pela beligerância opositora e pela aparente inércia do governo federal na tomada de decisões chaves para o país, como na condução das negociações econômicas com os representantes diplomáticos britânicos, exalou a todo momento ares conspiratórios advindos de diferentes instituições civis, políticas e militares em relação ao governo federal. No entanto, ainda que o jornal tenha estado, de fato, em consonância com esses grupos quanto à ineficácia administrativa do governo e da necessidade de uma firme atitude opositora e vigilante, não se pode perceber em seus 
editoriais, mesmos os mais próximos a setembro de 1930, uma tendência favorável à intervenção militar e à queda inconstitucional do governo.

Não se nega, porém, que o jornal possa ter flertado com a ideia de uma renúncia do presidente da República, no entanto, em nenhum momento o mesmo chegou a defender uma renúncia forçada com base na violência armada, mas sim por meio de uma pressão cívica sobre o governo, e em última instância sobre o Parlamento, o qual estava dotado de mecanismos constitucionais capazes de destituir o presidente da República de seu cargo, segundo o previsto na própria Constituição. Mas a realidade das fontes demonstra que, mesmo após a queda de Yrigoyen e a formação do governo provisório, o jornal continuou a se manter aliado do Parlamento e do retorno à normalidade constitucional, ainda que não tenha negado as razões que levaram à intervenção militar e nem a sua eficácia.

Conclui-se, portanto, que o jornal tenha tido constante postura crítica e opositora em relação ao segundo governo do presidente Yrigoyen, bem como aos atos por ele encabeçados, considerados pelo diário como um transvio de suas funções constitucionais e um desmonte autoritário das instituições republicanas. Estas foram construídas a partir de inúmeras crises e embates ao longo de décadas, das quais o próprio La Nación foi partícipe, direta ou indiretamente. Na mesma medida, concluímos que, ainda que tenha de fato reconhecido a intervenção militar de 6 de setembro de 1930 como algo necessário para a República, não é possível verificar, com base em suas posições editoriais, uma tendência favorável ao golpe militar antes de sua execução.

Em síntese, a postura opositora por parte do La Nación colaborou com a formação de uma pauta política antigovernista no Parlamento, em especial no Senado nacional, bem como em meio a poderosos grupos econômicos e políticos contrários ao governo. No entanto, sua postura crítica não evidencia uma correlação de sua ação para com os interesses dos grupos políticos e militares que buscavam derrubar o governo por vias inconstitucionais, mas sim uma defesa dos ideais fundacionais do jornal, resumidos no famoso lema cunhado por seu fundador: La Nación será una tribuna de doctrina. 


\section{Fontes}

Caras y Caretas In Hemeroteca Digital da Biblioteca Nacional da Espanha. № 1.666 e 1.667, 06/09/1930 e 13/09/1930. Disponível em: http://hemerotecadigital.bne.es/results.vm?q=parent\%3A0004080157\&lang=es\&s=166 0. Acesso em: 13 julho 2016.

La Nación In Biblioteca del Congreso de la Nación Argentina, microfilmes 19.544 a 19.556 (ano de 1928), 27.502 a 27.519 (anos de 1929 e 1930). 
LUGONES, Leopoldo. Acción: Las cuatro conferencias patrióticas del Coliseo: 6, 11, 14 y 17 de julio de 1923. Buenos Aires: Est. Gráfico A. de Martino, 1923. Disponível em: http://www.bnm.me.gov.ar/cgibin/wxis.exe/opac/?IsisScript=opac/bibdig.xis\&dbn=LU GONES\&src $=$ link\&tb=tem\&query $=$ CONFERENCIAS \&cantidad $=\&$ formato $=$ breve \&sa la. Acesso em: 20 novembro 2015.

LUGONES, Leopoldo. Payador y antologia de poesia y prosa. Caracas: Biblioteca Ayacucho, 1979.

Bibliografia

\section{Artigos}

ÁLVAREZ GUERREIRO, Osvaldo. Hipólito Yrigoyen ante la condición humana. Revista Polis: Revista Latinoamericana. Disponível em: http://polis.revues.org/5437. Acesso em: 15 agosto 2015. 
CORNBILT, Oscar. La opción conservadora en la política argentina. Desarrollo Económico, vol. 14, no 56, 1975. Disponível em: http://www.educ.ar. Acesso em: 14 setembro 2014, pág. 6.

JUNIOR, Antonio Carlos Dias. Raymond Aron leitor de Vilfredo Pareto: classe sociais, circulação de elites e mudança social. GT 29 - Teoria Social Contemporânea. XXX Congresso da Associação Latinoamericana de Sociologia. 2015. Disponível em: http://ciem.ucr.ac.cr/alas/docs/GT29/Raymond\%20aron\%20leitor\%20de\%20vilfredo\%20pareto\%20classes $\% 20$ sociais $\% 2$ 0circula\%C3\%A7\%C3\%A3o\%20das\%20elites\%20e\%20mudan\%C3\%A7a\%20social.d ocx. Acesso em: 03 janeiro 2016.

OSZLAK, Oscar. Reflexiones sobre la formación del Estado y la construcción de la sociedad argentina. Desarrollo Económico, Vol. 21, $\mathrm{N}^{\mathrm{o}}$ 84, 1982, pp. 531-548. Disponível em: http://www.jstor.org/stable/3466613?seq=1\#page_scan_tab_contents. Acesso em: 08 setembro 2016.

TATO, Maria Inés. Crónica de un desencanto: una mirada conservadora de la democratización de la política, 1911-1930. Estudios sociales 20. Revista Universitaria Semestral, No 20, 2001, pp. 143-163.

RÜDIGER, Francisco. As teorias da imprensa do liberalismo tardio na era do jornalismo de massas. $9^{\circ}$ Encontro Nacional de História da Mídia UFOP - Ouro Preto, 2013. Disponível em: http://www.ufrgs.br/alcar/encontros-nacionais-1/9o-encontro2013/artigos/gt-historia-do-jornalismo/as-teorias-da-imprensa-do-liberalismo-tardio-naera-do-jornalismo-de-massas. Acesso em: 19 junho 2015.

KIRSCHNER, Tereza. A reflexão conceitual na prática historiográfica. Textos de História, vol. 15, $\mathrm{n}^{\circ} 1 / 2, \quad 2007$. Disponível em: http://seer.bce.unb.br/index.php/textos/article/view/959. Acesso em: 20 novembro 2015, p. 2.

\section{Livros}

ANGEL CÁRCANO, Miguel. Saenz Peña: la revolucion por los comicios. Biblioteca Argentina de Historia y Politica. Buenos Aires: Hyspamérica Ediciones Argentina, 1986.

ARON, Raymond. Etapas do pensamento sociológico. Brasília: Editora da UnB, 1990.

BANDEIRA, Moniz. O Expansionismo brasileiro e a formação dos Estados na Bacia do Prata. $3^{\text {a }}$ ed. Brasília: UnB, 1998.

BARBERO, María Inés; DEVOTO, Fernando. Los Nacionalistas (1910-1932). Biblioteca Politica Argentina. Buenos Aires: Centro Editor de América Latina, 1983.

BEIRED, José Luis Bendicho. Sob o signo da nova ordem: Intelectuais autoritários no Brasil e na Argentina. São Paulo: Ed. Loyola, 1999, p. 61. 
BELTRAN, Oscar R. Historia del Periodismo Argentino. Buenos Aires: Sopena Argentina, 1943.

BERTONI, Lilia Ana; DE PRIVITELLIO, Luciano (Org.). Conflictos en la democracia: la vida política argentina entre dois siglos 1852-1943. Buenos Aires: Siglo Veintiuno Editores, 2009.

BOBBIO, Norberto; PASQUINO Gianfranco. Dicionário de Política. 13ª ed. Brasília, Ed. UnB, 2007.

CATTARUZZA, Alejandro. Historia de la Argentina 1916-1955. $2^{\mathrm{a}}$ ed. Buenos Aires: Siglo Veintiuno Editores, 2012.

DARNTON, Robert. Boemia Literária e Revolução: o submundo das letras no Antigo Regime. São Paulo: Companhia das Letras, 2007.

Robert. O Grande Massacre de Gatos: e outros episódios da história cultural francesa. São Paulo: Graal, 2011.

DEVOTO, Fernando. Nacionalismo, fascismo y tradicionalismo en la Argentina moderna. Una historia. Buenos Aires: Siglo XXI, 2002.

DE MARCO, Miguel Ángel. Bartolomé Mitre: Biografía. Buenos Aires: Editorial Planeta Argentina, 1998.

, Miguel Ángel (Org.). Nueva Historia de la Nación Argentina. Tomo IV. Buenos Aires: Planeta, 2001.

Miguel Ángel (Org.). Nueva Historia de la Nación Argentina. Tomo VIII. Buenos Aires: Planeta, 2001.

DE SANTILLÁN, Diego Abad. La F.O.R.A.: Ideologia y Trayectoria del movimiento obrero revolucionario em la Argentina. Buenos Aires: Ediciones HL, 2006.

DI TELLA, Torcuato S. História social da Argentina contemporânea. Brasília: FUNAG, 2010.

FERNANDEZ, Juan Rómulo. Historia del Periodismo Argentino. Buenos Aires: Libreria Perlado, 1943.

FINCHELSTEIN, Federico. Fascismo, liturgia e imaginário. El mito del general Uruburu y la Argentina nacionalista. Buenos Aires: Fondo de Cultura Económica, 2002.

Federico. La Argentina fascista: los orígenes ideológicos de la dictadura. Nudos de la Historia Argentina. Buenos Aires: Sudamerica, 2008.

FLORIA, Carlos. Pasiones nacionalistas. Buenos Aires: Fondo de Cultura Económica, 1998.

FLORIA, Carlos; GARCÍA BELSUNCE, César A. Historia de los argentinos. Tomo II. Buenos Aires: Ediciones Larousse Argentina, 1992.

GALVAN MORENO, Carlos. El periodismo argentino: amplia y documentada historia desde sus origenes hasta el presente. Buenos Aires: Claridad, 1944. 
GALVEZ, Manuel. Vida de hipolito yrigoyen, el hombre del misterio. Buenos Aires: G Kraft, 1939.

GIACOBONE, Carlos; GALLO, Edit Rosalía. Radicalismo bonaerense 1891-1931: la ingeniería política de Hipólito Yrigoyen, Buenos Aires: Corregidor, 1999.

GRYNSZPAN, Mário. Ciência política e trajetórias sociais: uma sociologia histórica da teoria das elites. Rio de Janeiro: Ed. Fundação Getulio Vargas, 1999.

HALPERIN DONGHI, Tulio. El revisionismo histórico argentino como vision decadentista de la historia. Buenos Aires: Siglo XXI, 2005.

Madrid: Ed. Alianza, 2010. , Tulio. Historia Contemporánea de America Latina. $21^{\mathrm{a}}$ ed. Tulio. Vida y muerte de la República verdadera (1910-1930).

Biblioteca del Pensamiento Argentino IV. Buenos Aires: Emecé, 2007.

HOROWITZ, Joel. Argentina's Radical Party and Popular Mobilization, 1916-1930. Pennsylvania: Penn State Press, 2008.

LUNA, Félix. Breve Historia de los Argentinos. 11ª ed., Buenos Aires: Planeta, 2003.

Félix. Alvear. Biblioteca Argentina de Historia y Politica. Buenos Aires: Hyspamérica Ediciones Argentina, 1986.

Félix. Historia Integral de la Argentina: Los años de prosperidad. Tomo VIII. Buenos Aires: Editorial Planeta Argentina, 1997.

Félix. Historia Integral de la Argentina: Conservadores y Peronistas. Tomo IX. Buenos Aires: Editorial Planeta Argentina, 1997.

Félix. Yrigoyen. Buenos Aires: Desarrollo, 1964.

MCGEE DEUTSCH, Sandra. Contrarrevolución en la Argentina: La Liga Patriótica Argentina (1900-1932). Buenos Aires: Universidad Nacional de Quilmes Editorial, 2003.

, Sandra. Las derechas: The extreme right in Argentina, Brazil and Chile. 1890-1939. Stanford: Stanford University Press, 1999.

MUTSUKI, Noriko. Julio Irazusta. Treinta años de nacionalismo argentino. Buenos Aires: Editorial Biblos, 2004.

POTASH, Robert A. El ejercito y la politica en la Argentina 1928-1945: de Yrigoyen a Perón. Buenos Aires: Ed. Sudamericana. 15ª ed, 1994.

QUATTROCCHI-WOISSON, Diana. Los males de la memória. Historia y política en la Argentina. Buenos Aires: Emecé, 1995.

QUIJADA, Mónica. Hipolito Yrigoyen. Buenos Aires: Ediciones Quorum, 1987.

RAPOPORT, Mario. De Pellegrini a Martínez de Hoz: el modelo liberal.. Buenos Aires: CEAL, 1984.

Mario. Historia económica, política y social de la Argentina (1880-

2000). Buenos Aires: Ed. Macchi, 2000. 
ROCK, David. La Argentina Autoritaria: Los Nacionalistas, su historia y su influencia en la vida pública. 2. ed. Buenos Aires: Editora Ariel, 1993.

David. Argentina 1516-1982: from spanhish colonizacion on the falklands war. Berkeley: Univ California, 1985.

David. El Radicalismo argentino. Buenos Aires: Amorrortu, 1977.

ROMERO, Luis Alberto. História Contemporânea da Argentina. Rio de Janeiro: Jorge Zahar Ed., 2006.

RORIZ, Diogo D'Angelo de Araujo. La Hora de la Espada: as origens do movimento nacionalista argentino (1920-1930). 2013. 42 f. Monografia (Bacharelado e Licenciatura em História) — Universidade de Brasília, Brasília, 2013.

RAÚl SATAS, Hugo. Uma Política Exterior Argentina. Buenos Aires: Hyspamerica, 1987.

ROUQUIÉ, Alain. Poder militar y sociedad política en la Argentina: hasta 1943. Buenos Aires, Emecé, 1994.

SABSAY, Fernando L; ETCHEPAREBORDA, Roberto. El Estado Liberal Democrático. Buenos Aires: Ed. Eudeba-Macchi, 1987.

SEBRELI, Juan José. Crítica de las ideas políticas argentinas. $6^{\mathrm{a}}$ ed. Buenos Aires: Sudamericana, 2003.

SHUMWAY, Nicolás. La Invención de la Argentina: Historia de una Idea. 2 ed. Buenos Aires: Emecé, 2002.

TERÁN, Oscar. Historia de las ideas en la Argentina: diez lecciones iniciales, 18101980. Buenos Aires: Siglo XXI Editores Argentina, 2008.

Ulanovsky, Carlos. Paren las rotativas: una historia de grandes diarios, revistas y periodistas argentinos. Buenos Aires: Espasa Calpe, 1997.

, Carlos. Paren las rotativas I: 1920 - 1969. Buenos Aires: Emecé, 2005.

VIÑAS, David. Literatura argentina y politica: de los jacobinos porteños a la bohemia anarquista. Buenos Aires: Sudamericana, 1997.

KOSELLECK, Reinhart. Futuro passado: contribuição à semântica dos tempos históricos. Rio de Janeiro: Contraponto, 2006. 